Organisation de Coopération et de Développement Économiques

Organisation for Economic Co-operation and Development

14-Apr-2011

ENVIRONMENT DIRECTORATE

English - Or. English

JOINT MEETING OF THE CHEMICALS COMMITTEE AND

THE WORKING PARTY ON CHEMICALS, PESTICIDES AND BIOTECHNOLOGY

Cancels \& replaces the same document of 02 March 2011

REPORT OF THE OECD SEMINAR ON RISK REDUCTION THROUGH PREVENTION, DETECTION AND CONTROL OF THE ILLEGAL INTERNATIONAL TRADE IN AGRICULTURAL PESTICIDES

Series on Pesticides

No. 59

19 May 2010, OECD, Paris 
ENV/JM/MONO(2011)6 
OECD Environment, Health and Safety Publications

Series on Pesticides

No. 59

\section{Report of the OECD Seminar on Risk Reduction through Prevention, Detection and Control of the Illegal International Trade in Agricultural Pesticides}

INTER-ORGANIZATION PROGRAMME FOR THE SOUND MANAGEMENT OF CHEMICALS

A cooperative agreement among FAO, ILO, UNEP, UNIDO, UNITAR, WHO, World Bank and OECD

Environment Directorate

ORGANISATION FOR ECONOMIC COOPERATION AND DEVELOPMENT

Paris 2011 


\section{Also published in the Series on Pesticides}

No. 1 Data Requirements for Pesticide Registration in OECD Member Countries: Survey Results (1993)

No. 2 Final Report on the OECD Pilot Project to Compare Pesticide Data Reviews (1995)

No. 3 Data Requirements for Biological Pesticides (1996)

No. 4 Activities to Reduce Pesticide Risks in OECD and Selected FAO Countries. Part I: Summary Report (1996)

No. 5 Activities to Reduce Pesticide Risks in OECD and Selected FAO Countries. Part II: Survey Responses (1996)

No. 6 OECD Governments' Approaches to the Protection of Proprietary Rights and Confidential Business Information in Pesticide Registration (1998)

No. 7 OECD Survey on the Collection and Use of Agricultural Pesticide Sales Data: Survey Results (1999) [see also No.47]

No. 8 Report of the OECD/FAO Workshop on Integrated Pest Management and Pesticide Risk Reduction (1999)

No. 9 Report of the Survey of OECD Member Countries' Approaches to the Regulation of Biocides (1999)

No. 10 Guidance Notes for Analysis and Evaluation of Repeat-Dose Toxicity Studies (2000)

No. 11 Survey of Best Practices in the Regulation of Pesticides in Twelve OECD Countries (2001)

No. 12 Guidance for Registration Requirements for Pheromones and Other Semiochemicals Used for Arthropod Pest Control (2001)

No. 13 Report of the OECD Workshop on Sharing the Work of Agricultural Pesticide Reviews (2002)

No. 14 Guidance Notes for Analysis and Evaluation of Chronic Toxicity and Carcinogenicity Studies (2002).

No. 15 Persistent, Bioaccumulative and Toxic Pesticides in OECD Member Countries, (2002)

No. 16 OECD Guidance for Industry Data Submissions for Pheromones and Other Semiochemicals and their Active Substances (Dossier Guidance for Pheromones and other Semiochemicals) (2003) 
No. 17 OECD Guidance for Country Data Review Reports for Pheromones and Other Semiochemicals and their Active Substances (Monograph Guidance for Pheromones and other Semiochemicals) (2003)

No. 18 Guidance for Registration Requirements for Microbial Pesticides (2003)

No. 19 Registration and Work sharing, Report of the OECD/FAO Zoning Project (2003)

No. 20 OECD Workshop on Electronic Tools for data submission, evaluation and exchange for the Regulation of new and existing industrial chemicals, agricultural pesticides and biocides (2003)

No. 21 Guidance for Regulation of Invertebrates as Biological Control Agents (IBCAs) (2004)

No. 22 OECD Guidance for Country Data Review Reports on Microbial Pest Control Products and their Microbial Pest Control Agents (Monograph Guidance for Microbials) (2004)

No. 23 OECD Guidance for Industry Data Submissions for Microbial Pest Control Product and their Microbial Pest Control Agents (Dossier Guidance for Microbials) (2004)

No. 24 Report of the OECD Pesticide Risk Reduction Steering Group Seminar on Compliance (2004)

No. 25 The Assessment of Persistency and Bioaccumulation in the Pesticide Registration Frameworks within the OECD Region (2005)

No. 26 Report of the OECD Pesticide Risk Reduction Group Seminar on Minor Uses and Pesticide Risk Reduction (2005)

No. 27 Summary Report of the OECD Project on Pesticide Terrestrial Risk Indicators (TERI) (2005)

No. 28 Report of the OECD Pesticide Risk Reduction Steering Group Seminar on Pesticide Risk Reduction through Good Container Management (2005)

No. 29 Report of the OECD Pesticide Risk Reduction Steering Group Seminar on Risk Reduction through Good Pesticide Labelling (2006)

No. $30 \quad$ Report of the OECD Pesticide Risk Reduction Steering Group: The Second Risk Reduction Survey (2006)

No. 31 Guidance Document on the Definition of Residue [also published in the series on Testing and Assessment, No. 63] (2006, revised 2009)

No. 32 Guidance Document on Overview of Residue Chemistry Studies [also published in the series on Testing and Assessment, No. 64] (2006, revised 2009) 
No. 33 Overview of Country and Regional Review Procedures for Agricultural Pesticides and Relevant Documents (2006)

No. 34 Frequently Asked Questions about Work Sharing on Pesticide Registration Reviews (2007)

No. 35 Report of the OECD Pesticide Risk Reduction Steering Group Seminar on "Pesticide Risk Reduction through Better Application Technology" (2007)

No. 36 Analysis and Assessment of Current Protocols to Develop Harmonised Test Methods and Relevant Performance Standards for the Efficacy Testing of Treated Articles/Treated Materials (2007)

No. 37 Report on the OECD Pesticide Risk Reduction Steering Group Workshop "Pesticide User Compliance' (2007)

No. 38 Survey of the Pesticide Risk Reduction Steering Group on Minor Uses of Pesticides (2007)

No.39 Guidance Document on Pesticide Residue Analytical Methods [also published in the series on Testing and Assessment, No. 72] (2007)

No. 40 Report of the Joint OECD Pesticide Risk Reduction Steering Group EC-HAIR Seminar on Harmonised Environmental Indicators for Pesticide Risk (2007)

No. 41 The Business Case for the Joint Evaluation of Dossiers (Data Submissions) using Work-sharing Arrangements (2008)

No. 42 Report of the OECD Pesticide Risk Reduction Steering Group Seminar on Risk Reduction through Better Worker Safety and Training (2008)

No. 43 Working Document on the Evaluation of Microbials for Pest Control (2008)

Guidance Document on Magnitude of Pesticide Residues in Processed Commodities - only published in the Series on Testing and Assessment, No. 96 (2008)

No. 44 Report of Workshop on the Regulation of BioPesticides: Registration and Communication Issues (2009)

No. 45 Report of the Seminar on Pesticide Risk Reduction through Education / Training the Trainers (2009)

No. 46 Report of the Seminar on Pesticide Risk Reduction through Spray Drift Reduction Strategies as part of National Risk Management (2009)

No. 47 OECD Survey on Countries'Approaches to the Collection and Use of Agricultural Pesticide Sales and Usage Data: Survey Results (2009)

No. 48 OECD Strategic Approach in Pesticide Risk Reduction (2009) 
No. 49 OECD Guidance Document on Defining Minor Uses of Pesticides (2009)

No. 50 Report of the OECD Seminar on Pesticide Risk Reduction through Better National Risk Management Strategies for Aerial Application (2010)

No. 51 OECD Survey on Pesticide Maximum Residue Limit (MRL) Policies: Survey Results (2010)

No.52 OECD Survey of Pollinator Testing, Research, Mitigation and Information Management: Survey Results (2010)

No.53 Report of the $1^{\text {st }}$ OECD BioPesticides Steering Group Seminar on Identity and Characterisation of Micro-organisms (2010)

No. 54 OECD Survey on Education, Training and Certification of Agricultural Pesticide Users, Trainers and Advisors, and Other Pesticide Communicators: Survey Results (2010)

No. 55 OECD Survey on How Pesticide Ingredients Other than the Stated Pesticide Active Ingredient(s) are Reviewed and Regulated: Survey Results (2010)

No. 56 OECD MRL Calculator User Guide (2011)

No. 57 OECD MRL Calculator MRL Statistical White Paper (2011)

No. 58 Report of the OECD Seminar on Pesticide Risk Reduction Strategies Near/in Residential Areas (2011) 


\section{Published separately}

OECD Guidance for Country Data Review Reports on Plant Protection Products and their Active Substances-Monograph Guidance (1998, revised 2001, 2005, 2006)

OECD Guidance for Industry Data Submissions on Plant Protection Products and their Active Substances-Dossier Guidance (1998, revised 2001, 2005)

Report of the Pesticide Aquatic Risk Indicators Expert Group (2000)

Report of the OECD Workshop on the Economics of Pesticide Risk Reduction (2001)

Report of the OECD-FAO-UNEP Workshop on Obsolete Pesticides (2000)

Report of the OECD Pesticide Aquatic Risk Indicators Expert Group (2000)

Report of the 2nd OECD Workshop on Pesticide Risk Indicators (1999)

Guidelines for the Collection of Pesticide Usage Statistics Within Agriculture and Horticulture (1999)

Report of the [1st] OECD Workshop on Pesticide Risk Indicators (1997)

Report of the OECD/FAO Workshop on Pesticide Risk Reduction (1995)

\section{(C) OECD 2011}

Applications for permission to reproduce or translate all or part of this material should be made to: Head of Publications Service, RIGHTS@oecd.org, OECD, 2 rue André-Pascal, 75775 Paris Cedex 16, France 


\begin{abstract}
About the OECD
The Organisation for Economic Co-operation and Development (OECD) is an intergovernmental organisation in which representatives of 34 industrialised countries in North and South America, Europe and the Asia and Pacific region, as well as the European Commission, meet to co-ordinate and harmonise policies, discuss issues of mutual concern, and work together to respond to international problems. Most of the OECD's work is carried out by more than 200 specialised committees and working groups composed of member country delegates. Observers from several countries with special status at the OECD, and from interested international organisations, attend many of the OECD's workshops and other meetings. Committees and working groups are served by the OECD Secretariat, located in Paris, France, which is organised into directorates and divisions.

The Environment, Health and Safety Division publishes free-of-charge documents in ten different series: Testing and Assessment; Good Laboratory Practice and Compliance Monitoring; Pesticides and Biocides; Risk Management; Harmonisation of Regulatory Oversight in Biotechnology; Safety of Novel Foods and Feeds; Chemical Accidents; Pollutant Release and Transfer Registers; Emission Scenario Documents; and Safety of Manufactured Nanomaterials. More information about the Environment, Health and Safety Programme and EHS publications is available on the OECD's World Wide Web site (www.oecd.org/ehs/).
\end{abstract}

This publication was developed in the IOMC context. The contents do not necessarily reflect the views or stated policies of individual IOMC Participating Organizations.

The Inter-Organisation Programme for the Sound Management of Chemicals (IOMC) was established in 1995 following recommendations made by the 1992 UN Conference on Environment and Development to strengthen co-operation and increase international co-ordination in the field of chemical safety. The Participating Organisations are FAO, ILO, UNEP, UNIDO, UNITAR, WHO, World Bank and OECD. UNDP is an observer. The purpose of the IOMC is to promote coordination of the policies and activities pursued by the Participating Organisations, jointly or separately, to achieve the sound management of chemicals in relation to human health and the environment. 
This publication is available electronically, at no charge.

For this and many other Environment, Health and Safety publications, consult the OECD's

World Wide Web site (www.oecd.org/ehs/)

or contact:

OECD Environment Directorate, Environment, Health and Safety Division

2 rue André-Pascal

75775 Paris Cedex 16

France

Fax: (33-1) 44306180

E-mail: ehscont@oecd.org 


\section{FOREWORD}

This document is the report of the OECD Seminar on Risk Reduction through Prevention, Detection and Control of the Illegal International Trade in Agricultural Pesticides that took place on 19 May, 2010 at OECD, Paris, France, and was chaired by Dr. Wolfgang Zornbach of the German Federal Ministry of Food, Agriculture and Consumer Protection. It was attended by representatives of the pesticide regulatory authorities of 16 OECD countries, the European Commission, Estonia, Brazil and PR China, representatives from industry, and international experts such as national custom officers and inspectors.

This was the twelfth in a series of Seminars organised by the OECD Pesticide Risk Reduction Steering Group, a sub-group of the OECD Working Group on Pesticides. These Seminars focus on key issues in pesticide risk reduction of concern to OECD governments. The Seminars are intended to provide an opportunity for OECD governments to discuss the issues together with non-governmental stakeholders and to develop recommendations for further OECD activities.

The topic of "Illegal International Trade in Agricultural Pesticides" (covering both trade in counterfeited pesticides and trade in pesticides that are not registered in the country of destination) was selected for this seminar considering the significant impacts for pesticide risk reduction in the fields of human health, food chain safety, obsolete stocks, and the environment. Pesticides are among the most regulated products in the world, but international shipments of counterfeit active ingredients and finished products often escape oversight by pesticide regulators and custom offices in OECD countries. This does not only lead to a distortion of pesticide national, import/export markets but undermines the national legislation on registration, which aims at avoiding or reducing risks to human health, the environment and crops.

After a series of presentations on governments' and other stakeholders' approaches and experiences (copies of all presentations are in Annex 4), the Seminar discussed the various issues associated with the illegal international trade of pesticides: risks and consequences of using illegal pesticides, risks linked to the pesticide supply/logistical chain, existing systems in place in countries, difficulties faced by authorities and customs, etc. The Seminar developed a set of recommendations targeted at governments, industry, all stakeholders and OECD.

The Seminar report was approved out-of-session by the Working Group on Pesticides by written procedure that was finished on 15 January 2011.

This document is being published under the responsibility of the Joint Meeting of the Chemicals Committee and the Working Party on Chemicals, Pesticides and Biotechnology, which has agreed that it be unclassified and made available to the public. 


\section{TABLE OF CONTENTS}

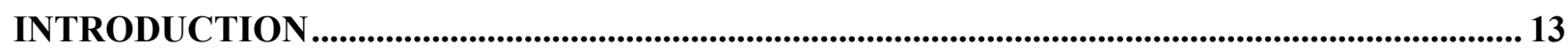

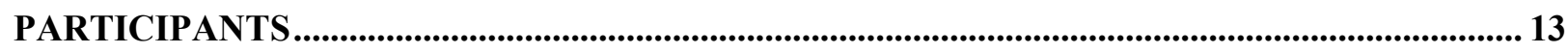

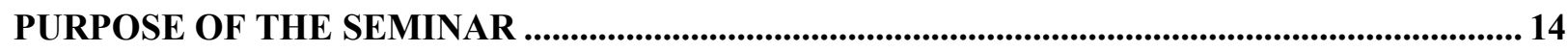

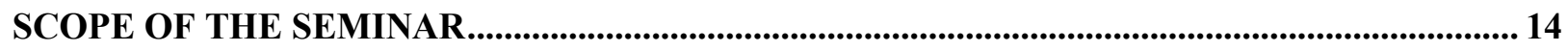

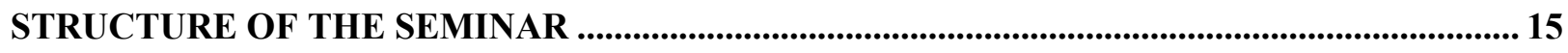

GOVERNMENT AND STAKEHOLDER EXPERIENCE, PERSPECTIVES AND

RECOMMENDATIONS ..................................................................................................................... 15

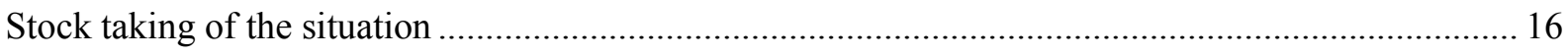

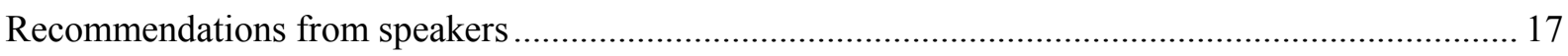

SEMINAR RECOMMENDATIONS TO THE VARIOUS STAKEHOLDERS............................... 19

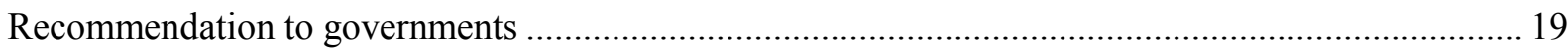

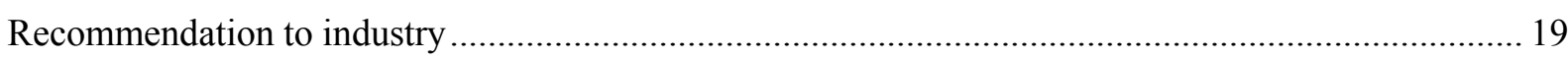

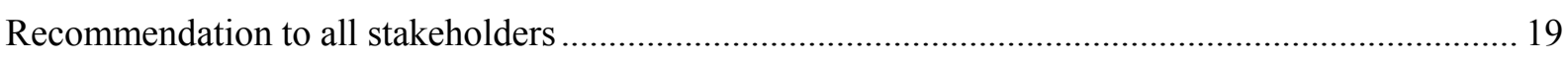

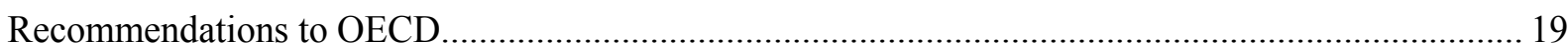

ANNEX 1: LIST OF OECD SEMINARS ON PESTICIDE RISK REDUCTION ..............................21

ANNEX 2: SEMINAR PROGRAMME..................................................................................................... 22

ANNEX 3: LIST OF PARTICIPANTS …...................................................................................................... 24

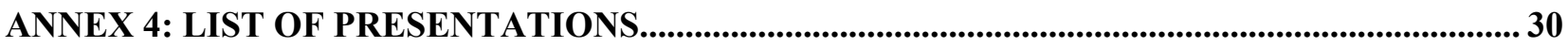




\section{INTRODUCTION}

1. This report presents the results and recommendations of an OECD Seminar on risk reduction through prevention, detection and control of the illegal international trade in agricultural pesticides. This one-day Seminar, held on 19 May 2010, was chaired by Wolfgang Zornbach (Germany), Chairman of the OECD Risk Reduction Steering Group (RRSG), and took place at OECD, in Paris, France.

2. This Seminar was the twelfth in a series of Seminars organised by the OECD RRSG, a sub-group of the OECD Working Group on Pesticides (WGP), a group composed primarily of representatives of the 34 OECD governments but that also includes representatives of the European Commission and other international organisations, the pesticide industry, and the environmental community. RRSG Seminars focus on key issues in pesticide risk reduction of concern to OECD countries. The Seminars are intended to provide an opportunity for OECD governments to discuss these issues together with non-governmental stakeholders and to develop recommendations for further follow-up OECD activities. The OECD Pesticides Programme has made great accomplishments toward helping national governments coordinate the efficiency and effectiveness of pesticide risk reduction work, in part because of Seminars such as the one held on pesticide illegal trade issues. Past OECD Risk Reduction Seminars are listed in Annex 1.

3. Members of the RRSG selected "Risk Reduction through Prevention, Detection and Control of the Illegal International Trade in Agricultural Pesticides" as the title and topic of this seminar considering the significant impacts for pesticide risk reduction in the fields of human health, food chain safety, obsolete stocks, and the environment. The worldwide increase in known incidents of illegal pesticides was noted during earlier OECD meetings of the WGP during which members requested a seminar on the topic. Pesticides are among the most regulated products in the world, but international shipments of counterfeit active ingredients and finished products often escape oversight by pesticide regulators and custom offices in OECD countries. This does not only lead to a distortion of pesticide markets but undermines the national legislation on registration, which aims at avoiding or reducing risks to human health, the environment and crops. With particular concern to the safe export and import of active ingredients and pesticide products, and taking into account the requirements of the Rotterdam Convention and the International Code of Conduct on the Distribution and Use of Pesticides, new practices and cooperation between stakeholders needed to be addressed to ensure that only legal pesticides are sold and used. Developing best practices and improved collaboration between pesticide regulators, customs, and other stakeholders was considered crucial for reducing risk to health and the environment.

\section{PARTICIPANTS}

4. People attending the OECD Seminar included:

- Representatives of the pesticide regulatory authorities of OECD countries (Australia, Austria, Belgium, Canada, Czech Republic, Denmark, Estonia, France, Germany, Japan, Mexico, the Netherlands, New Zealand, Slovak Republic, Switzerland, United Kingdom and United States), the European Commission, Brazil and PR China (two OECD enhanced engagement countries). 
- Representatives from industry, including CropLife International (an international association of pesticide manufacturers) and BIAC (Business and Industry Advisory Committee to the OECD)

- International experts dealing with issues associated with illegal trade of pesticides such as national custom officers and inspectors.

5. A participant list is provided in Annex 3.

\section{PURPOSE OF THE SEMINAR}

6. The main objectives of the Seminar were:

- to collect information about the extent of the problem and possible future trends

- to get a better overview of national current practices and activities for the control of imports/exports of agricultural pesticides

- to identify ways to improve information exchange and cooperation between regulators and customs within a country and among countries

- to identify ways to reduce risk through avoiding illegal trade of pesticides

- to suggest and discuss options of further steps for governments and key stakeholders in OECD and non-OECD countries in order to address the identified issues and implement solutions in an effective manner

- $\quad$ to recommend possible further steps for OECD work

\section{SCOPE OF THE SEMINAR}

7. The scope of the Seminar was on issues and risk reduction strategies regarding international illegal trade in agricultural pesticides. For the purpose of this Seminar, "illegal trade" refers to both:

- $\quad$ trade in counterfeited pesticides, and

- trade in pesticides that are not registered in the country of destination. 
8. In particular, the following issues were considered during the Seminar:

- Best practices in OECD countries to address risks of illegal trade of pesticides and possible elements for efficient risk reduction strategies (e.g. increased transparency, information sharing, traceability)

- Best practices by pesticide manufacturing countries to ensure legal exports of legal pesticides

- Potential risks inherent in current import/export systems

- How criminals avoid detection in shipping illegal pesticides

- Results of inspections and investigation cases

- Possible elements of risk reduction strategies

- Reasons for demands by growers for illegal pesticides (e.g. lower price, no other pesticides are available for minor uses)

- Recommendations for avoiding illegal trade and improving risk reduction strategies.

\section{STRUCTURE OF THE SEMINAR}

9. The first part of the Seminar in the morning and early afternoon was devoted to informative presentations from governments and other stakeholders. The second part of the afternoon consisted of roundtable discussions that built on issues that arose from the presentations, and recommendations for the OECD. The Seminar Programme is provided in Annex 2.

\section{GOVERNMENT AND STAKEHOLDER EXPERIENCE, PERSPECTIVES AND RECOMMENDATIONS}

10. First, government representatives of Australia, Brazil, China, France, Germany, and the US presented their experiences and initiatives with issues associated with illegal trade of pesticides in their own countries/regions. Then the European Commission introduced provisions related to exports of chemicals in the European Union arising from implementation of the Rotterdam Convention. Finally the industry (representing pesticide manufacturers) presented their actions, concerns and solutions related to unregulated international trade. Most presentations included informative examples of real cases of illegal trade of pesticides (e.g. seizures, custom controls, detection of illegal shipments, illegal behaviours, investigations) as well as speakers' strategies and own recommendations based on their experience to improve the situation and reduce illegal trade and shipments to a minimum. 
11. Below are listed the main topics covered in the presentations. More detailed and illustrative information can be found in the slides of presentations that are grouped in Annex 4.

\section{Stock taking of the situation}

- Various forms/aspects of illegal pesticides: in this Seminar, illegal pesticides referred to both counterfeited products and pesticides that are not registered in the country of destination. Participants presented numerous cases of deliberate 'illegality', such as mislabelling (e.g. wrong name, spelling mistake, fake batch numbers, unapproved label format) or misbranding (leading to patent or trademark infringements), inappropriate composition (e.g. an insecticide instead of a fungicide), use of wrong active ingredients or co-formulants, presence of impurities of concern, inappropriate bottles, unapproved or nonexistent manufacturing facility. In the European Union, some illegal/counterfeited products are fraudulently marketed as parallel import products. Some speakers also referred to cases leading to situations including obsolete pesticides.

- Current situation and trends in countries regarding illegal trade of pesticides: while most countries reported known cases of illegal pesticides, it is difficult to assess the actual size of the problem. Some countries do not have history or evidence of large-scale counterfeit products (e.g. US) whereas others (e.g. Brazil) estimate illegal trade accounting for a significant and growing part of their national pesticide trade.

- Risks and consequences of illegal pesticides: if the use of illegal pesticides may directly cause a number of problems associated with e.g. (unknown) health and environmental hazards, toxic residues in food, unexpected phyto-toxicity (damages to crops), low or inadequate product performance and efficiency leading to a reduction in farmers revenues, there are many other consequences for industry and governments. First, illegal trade generates costs on legitimate companies, affects their reputation and creates trade distortion and unfair business. Second, as it threatens the public, it may therefore undermine countries' registration systems and affect public trust and confidence in regulatory and compliance policies put in place by governments. Third, it imposes costs on the taxpayer for e.g. funding inspection, custom services or storage and destruction of seized products.

- Who's involved (and responsible) in pesticide illegal trade and counterfeiting? It appears that the whole supply and logistical chain is concerned in both OECD and non-OECD countries, from the actual "counterfeiters" to the exporters/importers, transport/vessel companies, wholesalers and distributors (who thus increase their profit margins) to the end-buyers (farmers and pesticide users). The demand side plays an important role in "encouraging" illegal pesticide sales hence the need to address minor use issues in particular. It was also mentioned that, as for any illegal activity, organized crime and corruption were part of the overall picture.

- Existing systems in place in countries: presentations described systems in place to control, prevent and fight against pesticide illegal trade and ultimately to ensure pesticide safety: import requirements, export certificates, checks of documents and control of shipments, anticounterfeiting brigade, etc. Countries often have multi-agency mechanisms involving cooperation among inter alia custom authorities, regulatory agencies, police/army, judges/prosecutors, foreign authorities or Europol (in the European Union). Governments have also developed comprehensive databases to help with the identification of illegal shipments of pesticides. At the international level, the Rotterdam Convention specifies the obligations (e.g. prior consent and 
export notification) related to the export of certain hazardous chemicals and pesticides. Rotterdam Convention information related to EU member states is centralized in the Edexim database (http://edexim.jrc.ec.europa.eu).

- Difficulties for countries and customs to control and seize illegal shipments: custom representatives explained that it may be very difficult to detect, stop and seize illegal pesticides. Most illegal products are not declared as "dangerous goods", shipping documents are unclear (and often importing and exporting documents for the same shipment are different/inconsistent), or fake/fraudulent names and misleading/deceptive labels are used. It may sometimes be very problematic for authorities to stop suspicious shipments for sampling and analysis, to collect evidence of fraud and to prove illegality. It was noted that in some larger countries where borders are very long, smuggling of pesticides was thus facilitated. To add to the complexity of the situation, often only the active ingredients are imported (under a false name/description) to avoid trademark counterfeiting/infringement, and the formulated products are prepared in the country of destination. In some countries/regions, the legal background was felt to be too weak, in particular as regards transit shipments, to allow authorities to seize illegal shipments. Finally, countries have also to address the problem of dealing with the seized products and (the costs of) their storage and destruction.

\section{Recommendations from speakers}

- Need for more transparency and traceability in shipping (export/import) documents: in view of the cases described in the above paragraph, some speakers made a plea for improving shipping documents in order to ensure that they are available to both regulators and customs in evaluating if pesticides are legal and registered in the country of manufacturer and in the country of intended use.

- Need for more compliance and enforcement tools and better risk analysis: many speakers recognised that more controls and enforcement actions would be necessary. They recommended developing more compliance tools, improving monitoring and inspections/controls along the whole supply chain and applying stronger administrative and financial sanctions. Risk analysis was also recognised as an important tool to better target potential illegal trade.

- Importance of training and communication: some countries put a lot of efforts on training to educate those concerned, such as importers, distributors or farmers, about the consequences of using illegal pesticides. Industry also devotes much time and money on anti-counterfeiting stewardship activities. Examples of educational materials, manuals, brochures, guidance documents or e-learning programmes were provided. It was emphasised that increasing awareness of the issues linked to pesticide illegal trade was important, e.g. through media coverage.

- Need for more international cooperation: all speakers agreed that, due to the increasing globalization of pesticide trade, international cooperation was key. Although some information networks already exist in some regions (e.g. in the European Union), stronger cooperation mechanisms with foreign authorities, between exporting and importing countries, between custom and regulatory authorities, were encouraged. Suggestions were made to establish an international cooperation structure. As a major pesticide exporter, China mentioned that they 
signed Memoranda of Understanding with many countries and indicated that they were willing to cooperate with OECD countries.

12. Following the presentations that addressed many issues associated with illegal trade of pesticides, as listed in the above paragraphs, the floor was opened to all Seminar participants for a roundtable discussion. The following points guided the discussion:

- Key issues concerning pesticide risk reduction through avoiding illegal trade in pesticides

- Key issues for the improvement of information exchange and cooperation between regulators and customs within a country as well as between countries

- Reasons for demands for illegal pesticides and communication aspects

- Good practices and innovative approaches as regards the control of both imports and exports of agricultural pesticides

- Solutions for reducing the risks from illegal international trade of pesticides

- Opportunities for further development for all stakeholders, governments, industry and OECD.

13. As an introduction to the discussion, the Chair invited participants to reflect on the actual scale of the problem associated with illegal trade of pesticides. Are cases presented by speakers isolated/single cases? Or is the problem larger than what is visible? It was mentioned that due to the very nature of the problem, it was difficult to have realistic figures. Data are based on scattered data, e.g. collected during controls and investigations. The Seminar participants however acknowledged that countries and industry were facing a serious problem that needed to be addressed whatever its actual size was. As with any other illegal activity, government participants agreed that they could not accept any form/level of illegal trade of pesticides.

14. All participants made knowledgeable interventions which contributed to a better understanding of the issues associated with illegal and counterfeited pesticides, and helped the group reach recommendations on follow-up steps for OECD and other stakeholders on this topic. 


\section{SEMINAR RECOMMENDATIONS TO THE VARIOUS STAKEHOLDERS}

15. The recommendations from the seminar participants to the various stakeholders are the following:

Recommendation to governments

a. Increasing cooperation between customs and pesticide regulatory authorities

$\rightarrow$ Customs and regulatory authorities should be better connected. The Seminar recommended using experience gained in sectors other than pesticides to find ways to develop communication channels between the two authorities. Training of custom officers about illegal pesticides was encouraged. Sharing of findings from controls and investigations would also be critical. It was suggested that increased cooperation may be linked to changes in the legal framework.

Recommendation to industry

b. Introducing a more effective anti-counterfeit protection

$\rightarrow$ Trade marks should be used on all packaging in order to better protect goods.

\section{Recommendation to all stakeholders}

c. Ensuring traceability along the pesticide chain

$\rightarrow$ Pesticides should be better identified and traced in the export/import chain. The product labels/containers and the corresponding shipping documents should be more explicit about their content, origin and destination. The quality of shipping documents should be improved and easy access should be made possible to both regulators and customs. All links in the chain (sellers, buyers and transporters) should know who their suppliers and customers are.

\section{Recommendations to OECD}

d. Setting an OECD network of experts and inspectors knowledgeable and active in fighting illegal trade of pesticides that could be used for rapid exchange of information on suspicious or rejected shipments

$\rightarrow$ Participants indicated that it would be important to create opportunities for more efficient exchange of information among national competent authorities and between authorities and industry on suspicious and rejected shipments. OECD should facilitate the process by collecting, centralizing and disseminating within the network the details of those experts and inspectors. These persons could then become contact points if a "rapid alert system" was to be put in place. The extent of the exchange of information would need to be defined and agreed upon as it would be subject to limitations such as confidential business information. Issues related to language would need to be considered in light of OECD experience in similar projects. However, it was recognised that there was room for cooperation. 
e. Establishing an OECD forum for national competent authorities

$\rightarrow$ A forum should be established within the OECD framework where representatives of national competent authorities could discuss relevant issues with their counterparts, such as traceability, integrated inspection, risk analysis, risk communication or multilateral cooperation, with a view to exchanging experience, learning from each other and elaborating solutions to identified common problems.

\section{f. Reaching out to non-member countries}

$\rightarrow$ It was felt important to reach out to non-OECD countries as not only OECD countries are faced with illegal trade of pesticides. Involvement in OECD activities of Brazil and the People's Republic of China, two countries that participated in the seminar and expressed interest in further cooperation, is possible thanks to the OECD Enhanced Engagement programme with these countries.

The OECD should help reach out to other non-member countries as well.

\section{g. Establishing an effective communication platform about risks towards pesticide users/re-sellers \\ $\rightarrow$ Participants expressed the need to communicate effectively to the pesticide users/sellers, such as farmers, growers, retailers, distributors, about the risks of buying and using illegal and counterfeited pesticides. It was suggested establishing a platform, which could include a public website, information brochures or training sessions that would communicate the right messages to the targeted audiences.}

Note:

The recommendations developed by the Seminar participants will be forwarded to the relevant subsidiary bodies of the OECD Pesticides Programme, the members of which will consider these recommendations and agree on which one(s) to initiate, if any. 
ANNEX 1

LIST OF OECD SEMINARS ON PESTICIDE RISK REDUCTION

\begin{tabular}{|l|l|l|}
\hline \multicolumn{1}{|c|}{ Title of Seminar [references of publication] } & \multicolumn{1}{|c|}{ Date } & \multicolumn{1}{c|}{ Place } \\
\hline $\begin{array}{l}\text { Compliance and Risk Reduction } \\
E N V / J M / M O N O(2004) 6 \text { (Series on Pesticides No. 24) }\end{array}$ & $\begin{array}{l}10 \text { March } \\
2003\end{array}$ & Paris, France \\
\hline $\begin{array}{l}\text { Minor Uses and Pesticide Risk Reduction } \\
E N V / J M / M O N O(2005) 4 \text { (Series on Pesticides No. 26) }\end{array}$ & 4 Nov. 2003 & $\begin{array}{l}\text { Canberra, } \\
\text { Australia }\end{array}$ \\
\hline $\begin{array}{l}\text { Pesticide Risk Reduction through Good Container } \\
\text { Management } \\
E N V / J M / M O N O(2005) 12 \text { (Series on Pesticides No. 28) }\end{array}$ & 22 June 2004 & Bonn, Germany \\
\hline $\begin{array}{l}\text { Risk Reduction through Good Pesticide Labelling } \\
E N V / J M / M O N O(2006) 13 \text { (Series on Pesticides No. 29) }\end{array}$ & 1 March 2005 & Paris, France \\
\hline $\begin{array}{l}\text { Pesticide Risk Reduction through Better Application } \\
\text { Technology } \\
E N V / J M / M O N O(2007) 3 \text { (Series on Pesticides No. 35) }\end{array}$ & 30 Nov. 2005 & $\begin{array}{l}\text { Wellington, New } \\
\text { Zealand }\end{array}$ \\
\hline $\begin{array}{l}\text { Joint OECD/EC Seminar on Harmonised Environmental } \\
\text { Indicators For Pesticide Risk (HAIR) } \\
E N V / J M / M O N O(2007) 27 \text { (Series on Pesticides No. 40) }\end{array}$ & 13 Nov. 2006 & Bonn, Germany \\
\hline $\begin{array}{l}\text { Risk Reduction through Better Worker Safety and Training } \\
E N V / J M / M O N O(2008) 9 \text { (Series on Pesticides No. 42) }\end{array}$ & $\begin{array}{l}21 \text { March } \\
2007\end{array}$ & $\begin{array}{l}\text { Brno, } \\
\text { Republic }\end{array}$ \\
\hline $\begin{array}{l}\text { Risk Reduction through Education / Training the Trainers } \\
E N V / J M / M O N O(2009) 35 \text { (Series on Pesticides No. 45) }\end{array}$ & 15 Nov. 2007 & $\begin{array}{l}\text { Mexico } \\
\text { Mexico }\end{array}$ \\
\hline $\begin{array}{l}\text { Risk Reduction through Spray Drift Reduction Strategies as } \\
\text { Part of National Risk Management } \\
E N V / J M / M O N O(2009) 36 \text { (Series on Pesticides No. 46) }\end{array}$ & 12 June 2008 & Paris, France \\
\hline $\begin{array}{l}\text { Pesticide Risk Reduction through Better National Risk } \\
\text { Management Strategies for Aerial Application } \\
E N V / J M / M O N O(2010) 22 \text { (Series on Pesticides No. 50) }\end{array}$ & 24 Feb. 2009 & $\begin{array}{l}\text { San } \\
\text { US Francisco, }\end{array}$ \\
\hline $\begin{array}{l}\text { Pesticide Risk Reduction Strategies near/in Residential } \\
\text { Areas } \\
E N V / J M / M O N O(2011) 5 \text { (Series on Pesticides No. 58) }\end{array}$ & $\begin{array}{l}17 \text { November } \\
2009\end{array}$ & $\begin{array}{l}\text { Tokyo, Japan } \\
\end{array}$ \\
\hline
\end{tabular}

The reports from these Seminars are available on the OECD public web site at: http://www.oecd.org/env/pesticides, under the section "Risk Reduction." 


\section{ANNEX 2 \\ OECD SEMINAR ON RISK REDUCTION \\ THROUGH PREVENTION, DETECTION AND CONTROL \\ OF THE ILLEGAL INTERNATIONAL TRADE IN AGRICULTURAL PESTICIDES}

Wednesday 19 May 2010, OECD, Paris, France

Final Programme

Chair: Wolfgang Zornbach, Germany

\begin{tabular}{|c|c|}
\hline $9.30 \mathrm{am}$ & $\begin{array}{l}\text { Introduction } \\
\text { - Purpose and structure of the seminar } \\
\text { - Tour de table to introduce participants }\end{array}$ \\
\hline & $\begin{array}{l}\text { Government Experience and Perspectives (from OECD countries and others) } \\
\text { - Germany: Detection of shipments containing illegal Plant Protection Products in } \\
\text { the port of Hamburg - Experiences and strategies of the involved authorities } \\
\text { (Gregor Hilfert, BWA, Hamburg) } \\
\text { - USA: Ensuring Safety and Integrity of Imported Pesticide Products: The US } \\
\text { approach (Jay Ellenberger, US-EPA) } \\
\text { - Australia: Recent issues in Australia - illegal behaviour in the pesticides industry } \\
\text { (Eva Bennet-Jenkins, CEO, APVMA) } \\
\text { - People's Republic of China: Crack Down Illegal Trade to Promote Sustainable } \\
\text { Development of the Pesticide International Trade (Gu Baogen, Deputy Director } \\
\text { General, Institute for the Control of Agrochemicals (ICAMA), Ministry of } \\
\text { Agriculture) } \\
\text { - Brazil: Integrated inspections against the illegal pesticides (Marcelo } \\
\text { Bressan/Marcella Texeira, Ministry of Agriculture, Livestock and Food Supply) } \\
\text { - France: Investigations on counterfeit and illegal Plant Protection Products in } \\
\text { France and new thoughts about the means of fighting (Maurice Boureau, Brigade } \\
\text { Nationale d'Enquêtes Vétérinaires et Phytosanitaires (BNEVP)) }\end{array}$ \\
\hline & $\begin{array}{l}\text { Stakeholder Experience and Perspectives } \\
\text { - European Commission: Provisions related to exports of chemicals in the } \\
\text { European Union arising from implementation of the Rotterdam Convention } \\
\text { (Juergen Helbig, DG Environment) } \\
\text { - Industry (CropLife International): Counterfeit and illegal pesticides smuggling } \\
\text { caused by unregulated international trade (D'Arcy Quinn, CropLife International) }\end{array}$ \\
\hline & Lunch \\
\hline
\end{tabular}




\begin{tabular}{|c|c|}
\hline & $\begin{array}{l}\text { Round-table Discussion } \\
\text { - Key issues concerning pesticide risk reduction through avoiding illegal trade in } \\
\text { pesticides } \\
\text { - Key issues for the improvement of information exchange and cooperation between } \\
\text { regulators and customs within a country as well as between countries } \\
\text { - Reasons for demands by growers for illegal pesticides (e.g. lower price, minor use } \\
\text { gaps) and communication aspects } \\
\text { - Regulatory requirements that exist in different countries } \\
\text { - Good practices and innovative approaches as regards the control of both imports } \\
\text { and exports of agricultural pesticides. Possible elements for efficient risk reduction } \\
\text { strategies: } \\
\circ \text { more transparency in export / import documents and ensuring they are } \\
\quad \text { available to regulators and customs in evaluating if pesticides are legal and } \\
\text { registered in the country of manufacturer and in the country of intended use } \\
\circ \text { better and more effective information sharing with customs } \\
\circ \text { traceability in shipping documents } \\
\circ \text { pros and cons of domestic versus international inspections } \\
\circ \text { matching regulatory documents with import documents } \\
\circ \text { licensed sources of manufacturing. } \\
\text { Barriers to and solutions for reducing the risks from illegal international trade of } \\
\text { pesticides } \\
\text { Options for further steps: } \\
\circ \text { for OECD countries and key stakeholders in OECD and manufacturing } \\
\text { countries to address the identified issues } \\
\circ \text { for effective implementation of the above-mentioned options } \\
\circ \text { for OECD future work }\end{array}$ \\
\hline & $\begin{array}{l}\text { Summary of the discussion } \\
\text { Possible solutions and challenges for their effective implementation } \\
\text { Recommendations for further OECD work }\end{array}$ \\
\hline $6.00 \mathrm{pm}$ & End of the Seminar \\
\hline
\end{tabular}




\title{
ANNEX 3 \\ OECD SEMINAR ON RISK REDUCTION \\ THROUGH PREVENTION, DETECTION AND CONTROL \\ OF THE ILLEGAL INTERNATIONAL TRADE IN AGRICULTURAL PESTICIDES
}

\author{
Wednesday 19 May 2010 \\ OECD, Paris, France
}

\section{LIST OF PARTICIPANTS}

Australia/Australie

Austria/Autriche

Belgium/Belgique

Canada

Czech Republic/République Tchèque
Dr. Eva BENNET-JENKINS

CEO

Australian Pesticides \& Veterinary Medicines Authority

Mr. Johann KOHL

AGES Austrian Federal Agency for Health \& Food Safety

Institute for Plant Protection Products Evaluation \& Authorization

Mr. Steven BOVEN

Collaborateur

FAVV - Food Safety Center

M. Jean-François SCHMIT

Collaborateur

AFSCA - Politique de contrôle

Ms. Marion LAW

Chief Registrar

Pest Management Regulatory Agency

Health Canada

Karen REYNOLDS

Director, Submission and Information Management Division

Registration Directorate

Health Canada

Ms. Helena CIZKOVA

First Secretary

Permanent Delegation 
Denmark/Danemark

France

Germany/Allemagne
Mr. Leif Lykke NIELSEN

Chief Adviser

Danish Environmental Protection Agency

M. Maurice BOUREAU

Chargé d'enquêtes, relations internationales

Cellule phytosanitaire:

Ministère de l'Agriculture et de la Pêche

M. Bruno DESPAGNE

Enquêteur

Cellule phytosanitaire

Ministère de l'Agriculture et de la Pêche

M. Hervé GILLET

Chef de la cellule phytosanitaire

Ministère de l'Agriculture et de la Pêche

Mme Camille HOSTIOU

Juriste

Direction générale de l'alimentation (DGAL)/Service de la protection des risques sanitaires de la production primaire (SPRSPP)/ Sous-direction de la qualité et de la protection des végétaux (SDQPV)

Ministère de l'Alimentation, de l'Agriculture et de la Pêche

Bureau de la réglementation et de la mise sur le marché

M. Dominique JULIEN

Enquêteur

Cellule phytosanitaire

Ministère de l'Agriculture et de la Pêche

Mr. Vincent TIRILLY

Ministère de l'Agriculture et de la Pêche

SG/SDTPS

Bureau santé et sécurité au travail

Dr. Wolfgang ZORNBACH

Plant Protection Unit

Federal Ministry of Food, Agriculture and Consumer Protection (BMELV) 
Mr. Gregor HILFERT

Pflanzengesundheitskontrolle

Behörde für Wirtschaft und Arbeit (BWA)

Mrs. Andrea KUERBS

Bundesministerium der Finanzen (BMF)

Nils KURLEMANN

German Federal Office of Consumer Protection and Food Safety

Mrs. Brigitte WEIGAND

FB Genehmigung und Kontrollen

Landwirtschaftskammer NRW (LWK)

Japan/Japon

Ms. Atsuko HORIBE

Deputy Director

Agricultural Chemicals Office, Plant Products Safety Division

Ministry of Agriculture Forestry and Fisheries

Food Safety and Consumer Affairs Bureau

Dr. Noriko SARUTA

Deputy Director

Standards and Evaluation Division

Ministry of Health, Labour and Welfare

Department of Food Safety

Dr. Yukiko YAMADA

Deputy Director-General

Ministry of Agriculture, Forestry and Fisheries

Food Safety and Consumer Affairs Bureau

Mexico/Mexique

Dr. Eugenio DEISTER MATEOS

Executive Director

Sanitary Ruling

Federal Commission for the Protection against Sanitary Risks

Netherlands/Pays-Bas

Dr. Susanne SÜTTERLIN

Senior Officer

Directorate Agriculture

Ministry of Agriculture, Nature \& Food Quality 


$\begin{array}{lll}\text { New } & \text { Zealand/Nouvelle- } & \text { Mr. Warren HUGHES } \\ \text { Zélande } & \text { Senior Manager (ACVM Standards) } \\ \text { Approvals and ACVM Group } & \text { New Zealand Food Safety Authority } \\ & \\ & \text { Mr. John REEVE } \\ & \text { Principal Adviser (Toxicology) } \\ & \text { New Zealand Food Safety Authority }\end{array}$

Slovak Republic/République
slovaque

Switzerland/Suisse

United Kingdom/RoyaumeUni
Ms. Bronislava SKARBOVA

Department of Plant Commodities

Ministry of Agriculture of the Slovak Republic

Dr. Beat SCHMITTER

Federal Department of Economic Affairs

Federal Office for Agriculture

Mr. Paul ADAMSON

Enforcement Officer

Chemicals Regulation Directorate

Health and Safety Executive (Operations)

Mr. Richard DAVIS

Director of Regulatory Operations

Chemicals Regulation Directorate

Health and Safety Executive

Mr. Jay ELLENBERGER

Deputy Director, Field and External Affairs Division

Office of Pesticide Programs

US Environmental Protection Agency

Kathy MONK

Senior Regulatory Specialist

Office of Pesticide Programs

US EPA

Ms. Lois ROSSI

Director

Registration Division

US Environmental Protection Agency

Office of Pesticide Programs 
EU/UE

Estonia/Estonie

Brazil/Brésil
Mr. Wolfgang REINERT

Administrator

Health \& Consumers Directorate-General

European Commission

Mr. Juergen HELBIG

Policy Officer

DG Environment

European Commission

Unit D3 - Chemicals and Nanomaterials

Miss Evelin HILLEP

Head of Bureau

Plant Health Department Plant Protection Bureau

Ministry of Agriculture, Republic of Estonia

Mr. Marcelo BRESSAN

Federal Inspector

Ministry of Agriculture

Ms. Marcella TEIXEIRA

Ministry of Agriculture of $\mathrm{Mr}$. Gu BAOGEN

China/République populaire Deputy Director General de Chine
Institute for control of Agrochemicals Ministry of Agriculture (ICAMA)

\author{
Business and Industry Mr. William GRAHAM \\ Advisory Committee International Regulatory Affairs Lead \\ (BIAC)/Comité consultatif Agricultural Sector \\ économique et industriel Monsanto UK Ltd \\ (BIAC)
}

Mr. Peter HORNE

Global Regulatory Affairs Manager

DuPont Crop Protection Products

Dr. Bernhard JOHNEN

Director International Regulatory Policy

CropLife International 
Dr. Michael KAETHNER

Head of Developmental Affairs

Bayer Crop Science AG

Dr. Felix MEIER-MANZ

Head Regulatory Support

Syngenta Crop Protection AG

Mr. Robby SCHREIBER

European Crop Protection Association

Mr. D'Arcy QUINN

Director Anti-Counterfeiting

CropLife International

M. Laurent GIEZENDANNER

Head of Corporate Security

Gerwin BOUILLON

Bayer CropScience AG

Dr. Tom MCHALE

DuPont UK Limited

Denis TROALEN

Sumitomo Chemical Agro Europe SA

Parc d'Affaires de Crécy

Mr. Gerold MARTI

Syngenta International AG

Ms. Beatrice GRENIER

ENV/EHS

OECD

Ms. Sylvie PORET

Principal Administrator

ENV/EHS

OECD 
ANNEX 4

\section{List of presentations}

\section{Presentation 1}

Germany: Detection of shipments containing illegal Plant Protection Products in the port of HamburgExperiences and strategies of the involved authorities

Gregor Hilfert, BWA, Hamburg

\section{Presentation 2}

USA: Ensuring Safety and Integrity of Imported Pesticide Products: The US approach Jay Ellenberger, US-EPA

\section{Presentation 3}

Australia: Recent issues in Australia - illegal behaviour in the pesticides industry

Eva Bennet-Jenkins, CEO, APVMA

\section{Presentation 4}

People's Republic of China: Crack Down Illegal Trade to Promote Sustainable Development of the Pesticide International Trade (Gu Baogen, Deputy Director General, Institute for the Control of Agrochemicals (ICAMA), Ministry of Agriculture)

\section{Presentation 5}

Brazil: Integrated inspections against the illegal pesticides

Marcelo Bressan/Marcella Texeira, Ministry of Agriculture, Livestock and Food Supply

\section{Presentation 6}

France: Investigations on counterfeit and illegal Plant Protection Products in France and new thoughts about the means of fighting

Maurice Boureau, Brigade Nationale d'Enquêtes Vétérinaires et Phytosanitaires (BNEVP)

\section{Presentation 7}

European Commission: Provisions related to exports of chemicals in the European Union arising from implementation of the Rotterdam Convention

Juergen Helbig, DG Environment

\section{Presentation 8}

Industry: Counterfeit and illegal pesticides smuggling caused by unregulated international trade D'Arcy Quinn, CropLife International 


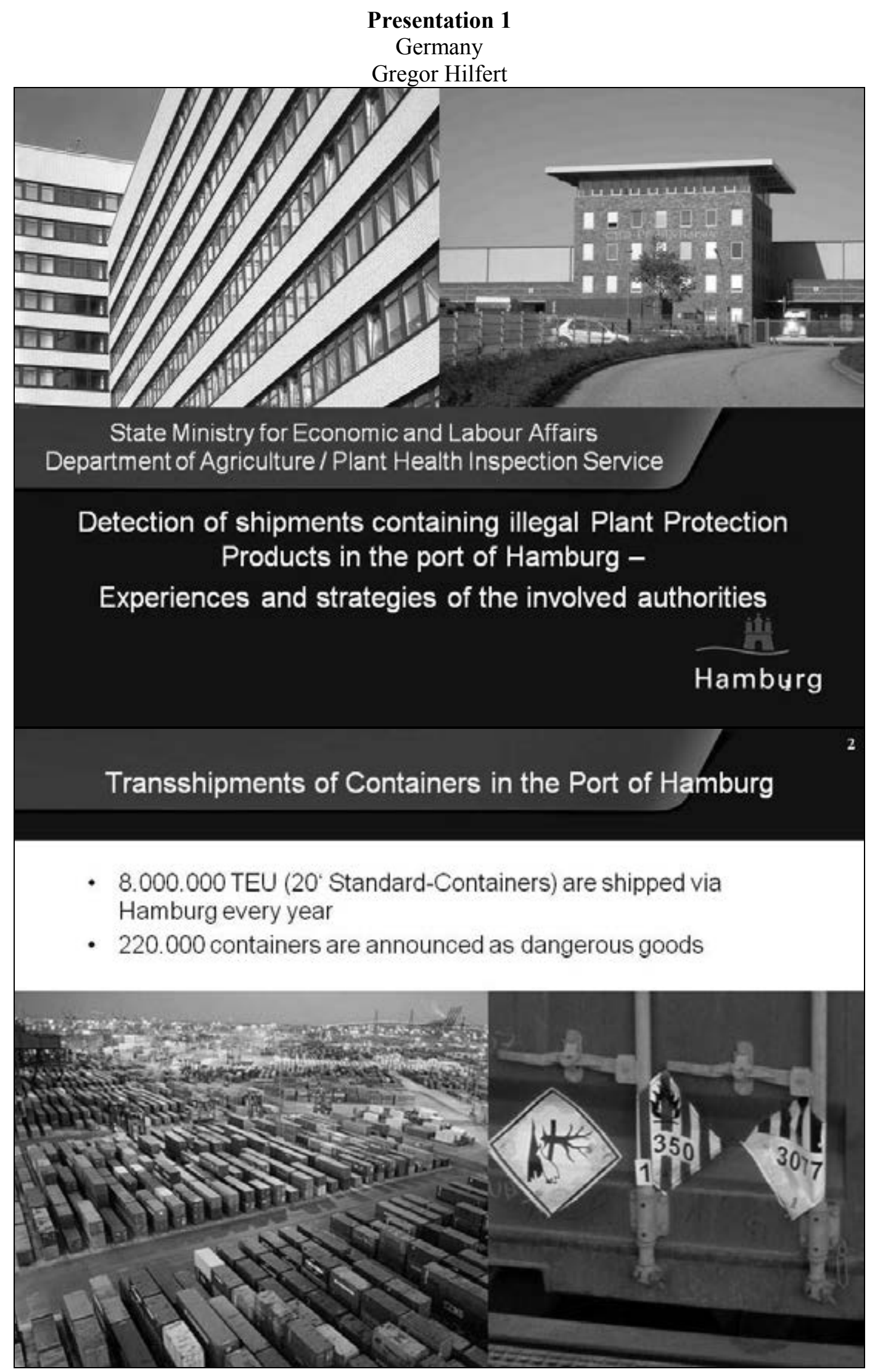




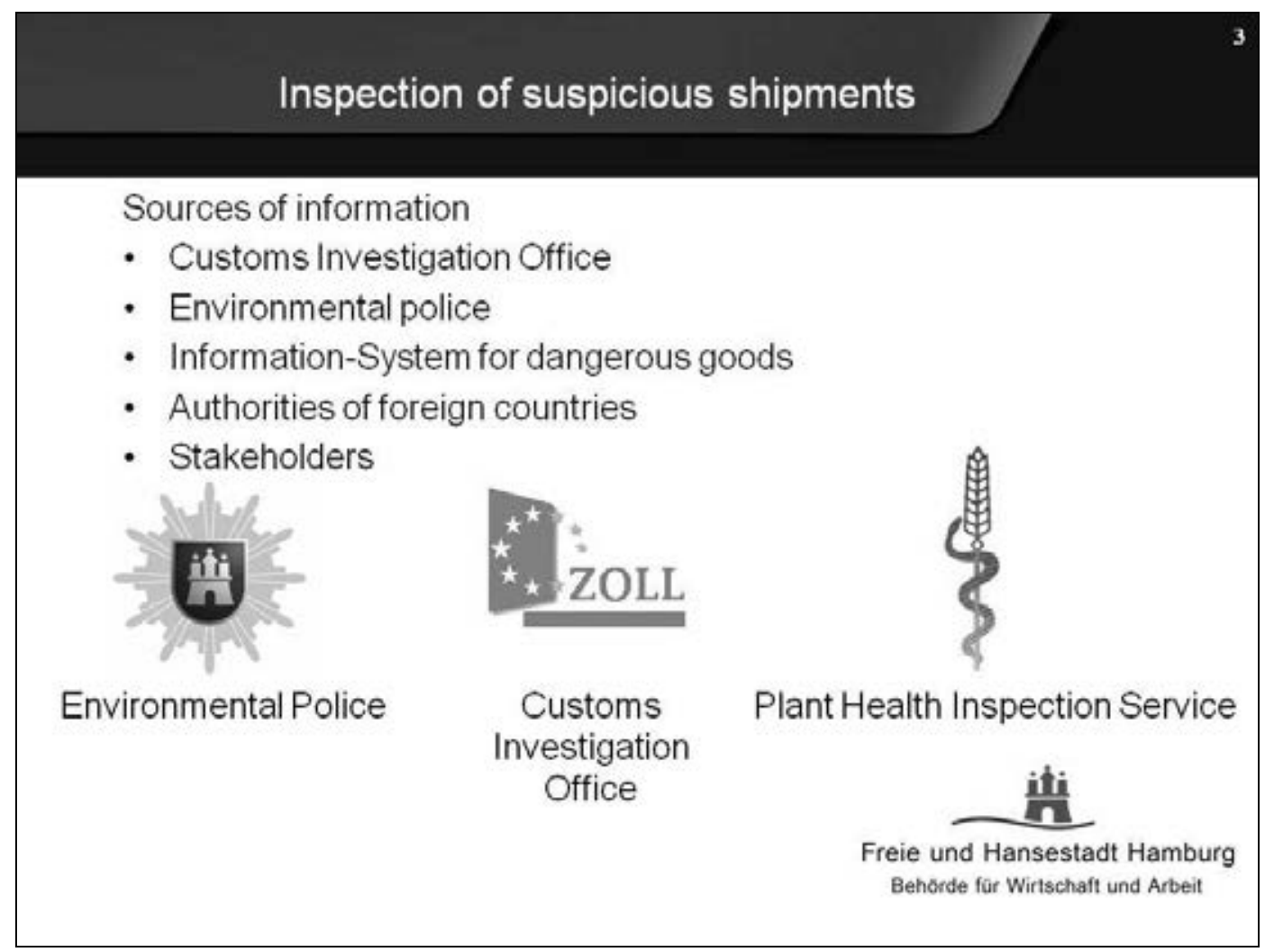

\section{Using the information system for dangerous goods}

\section{Every week:}

- Supervision of 1.500 containers announced as dangerous goods

- Inspection of freight documents: 30 Containers

- Forwarding of information to authorities in countries of destination: 1-2 Containers

- Opening of containers: 1-2

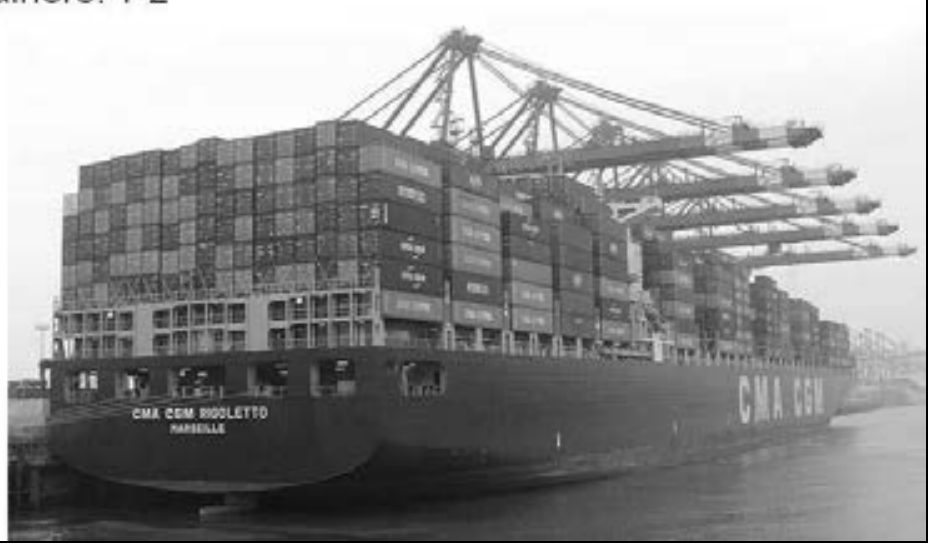



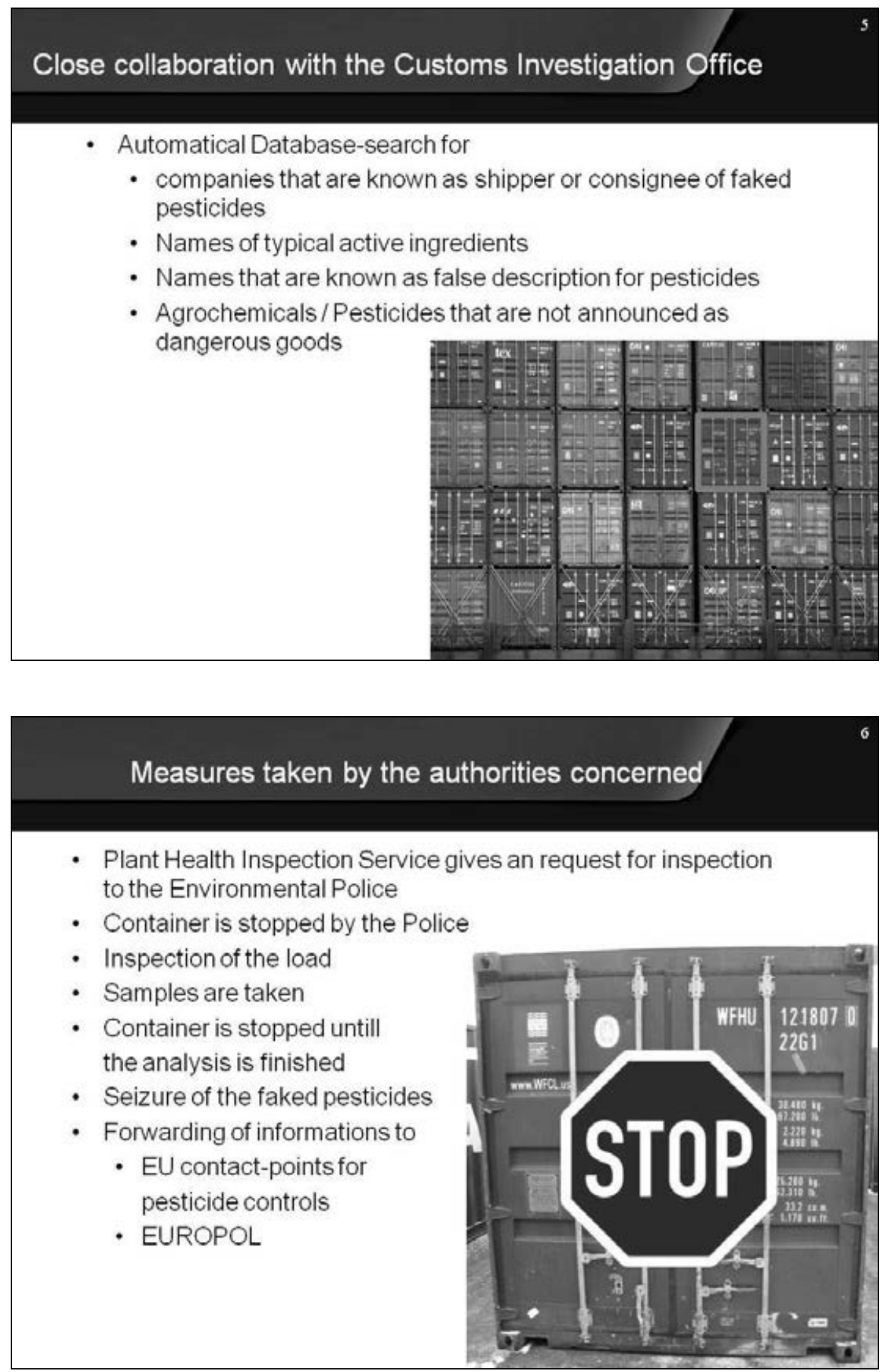


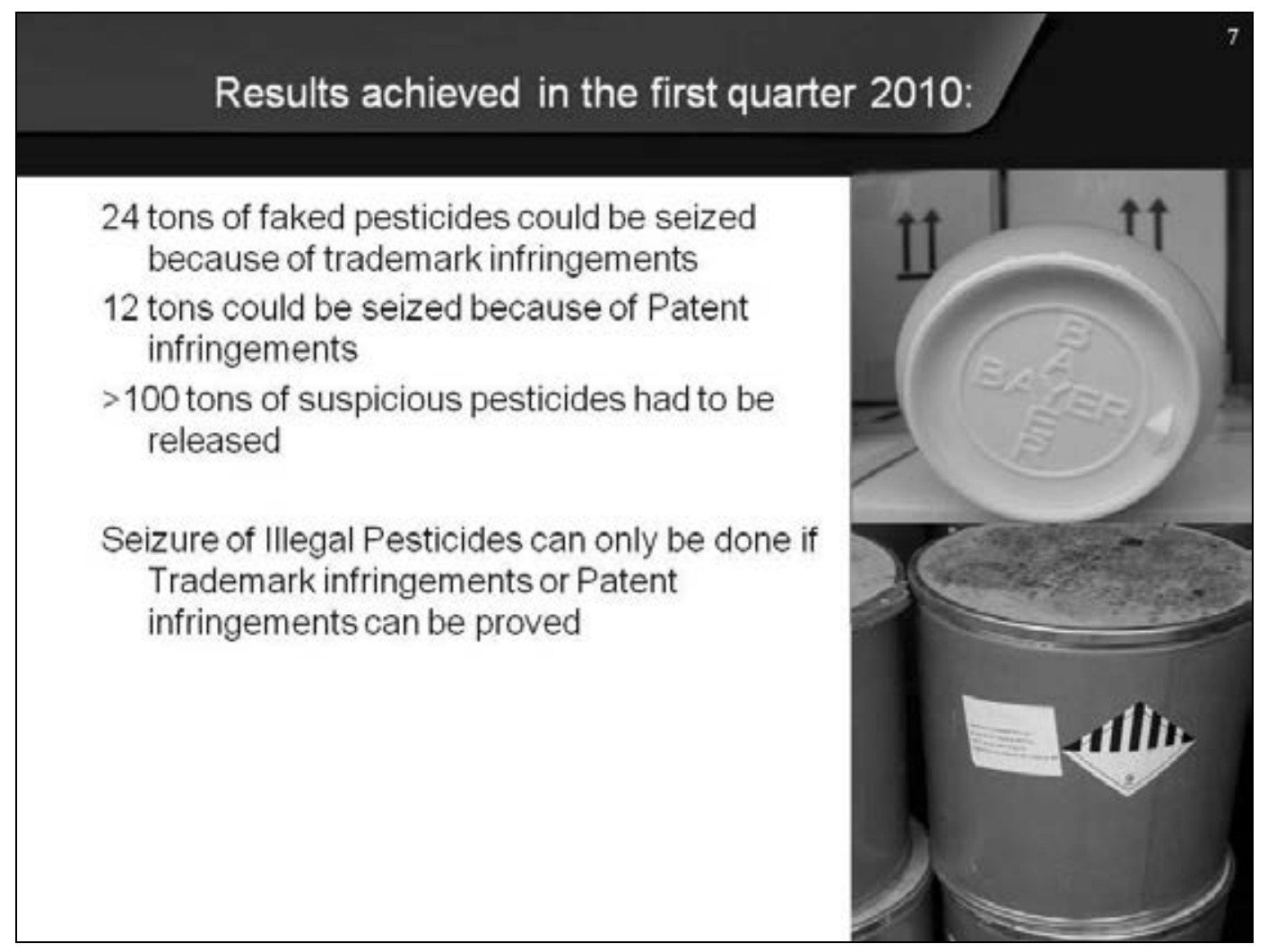

\section{„Emulsifier"-Shipment - January 2010}

- 23,4 tons of pesticides announced as "Emulsifier"

- No declaration as dangerous goods

- Company named as consignee doesn't exist

- Place of delivery: Klaipeda (Lithuania)

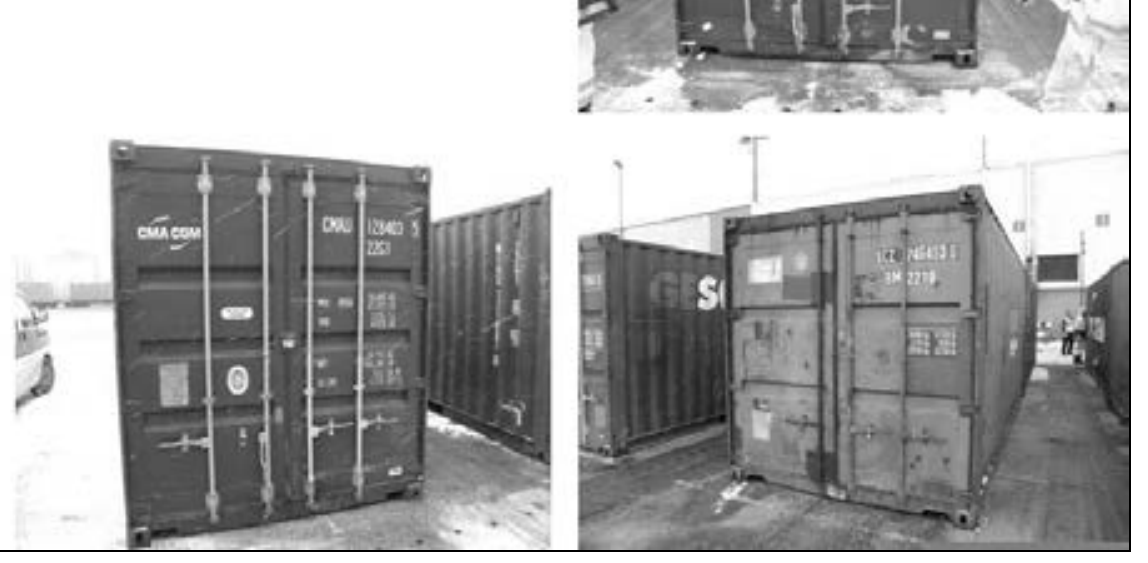



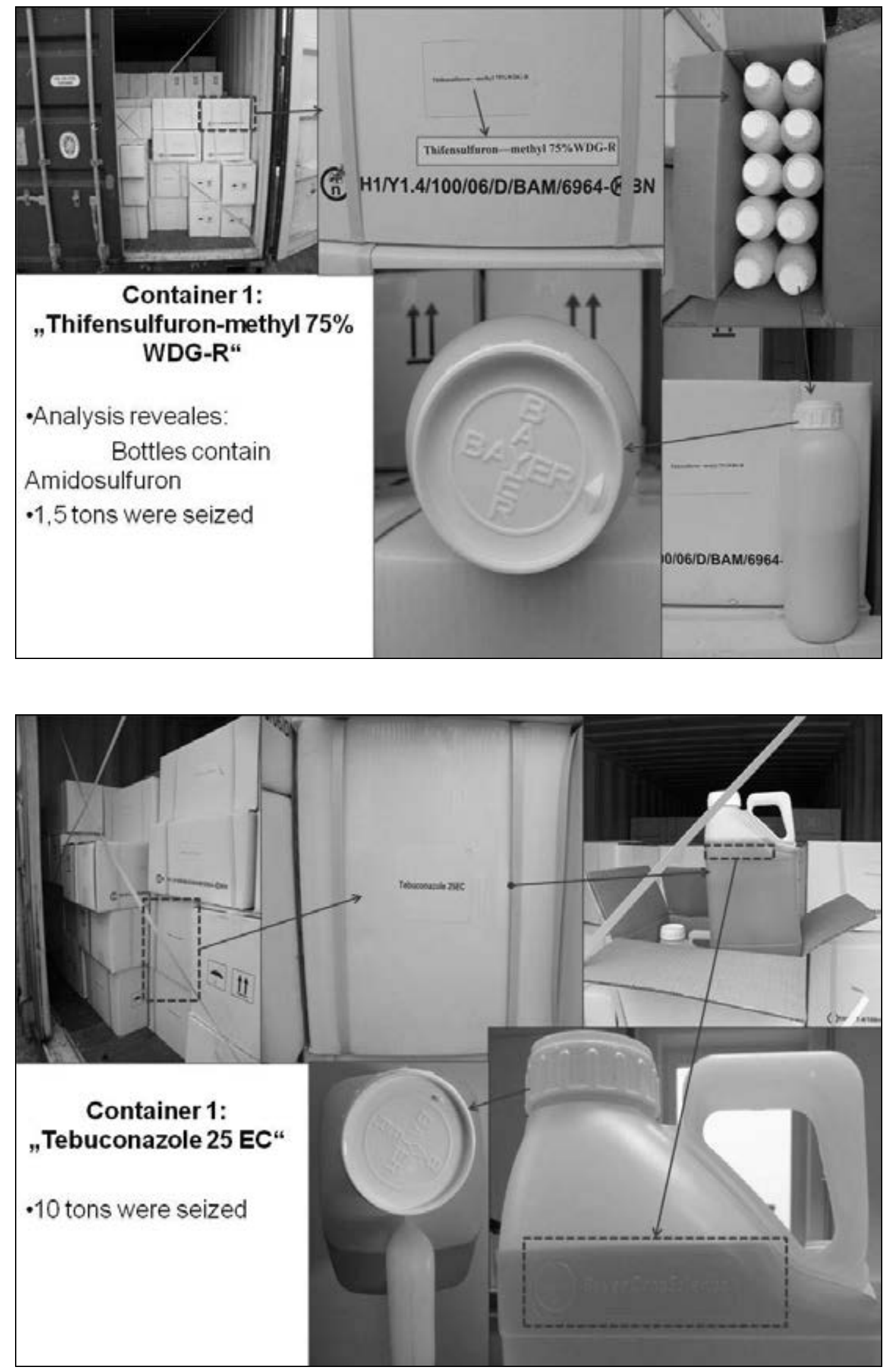

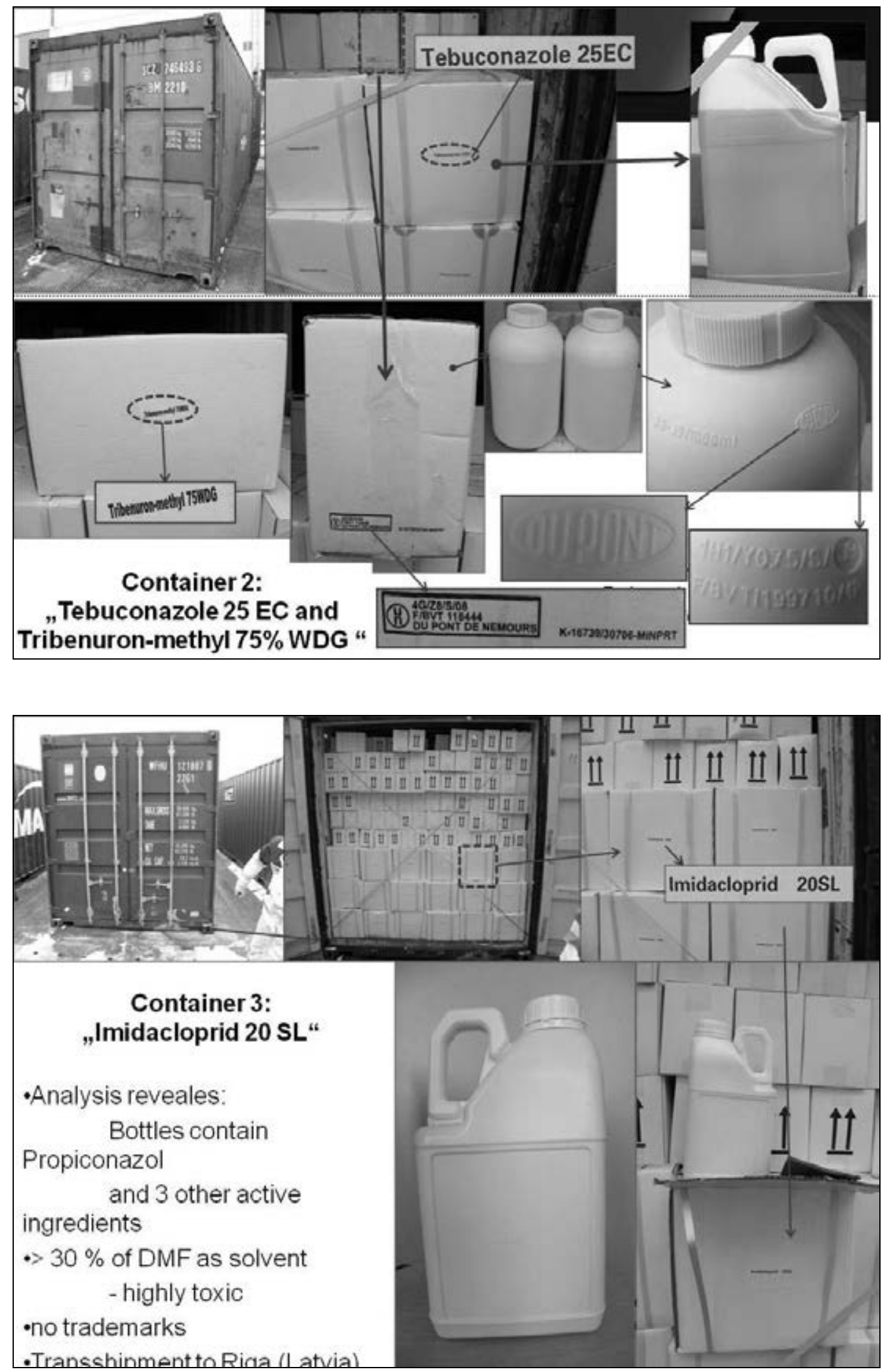

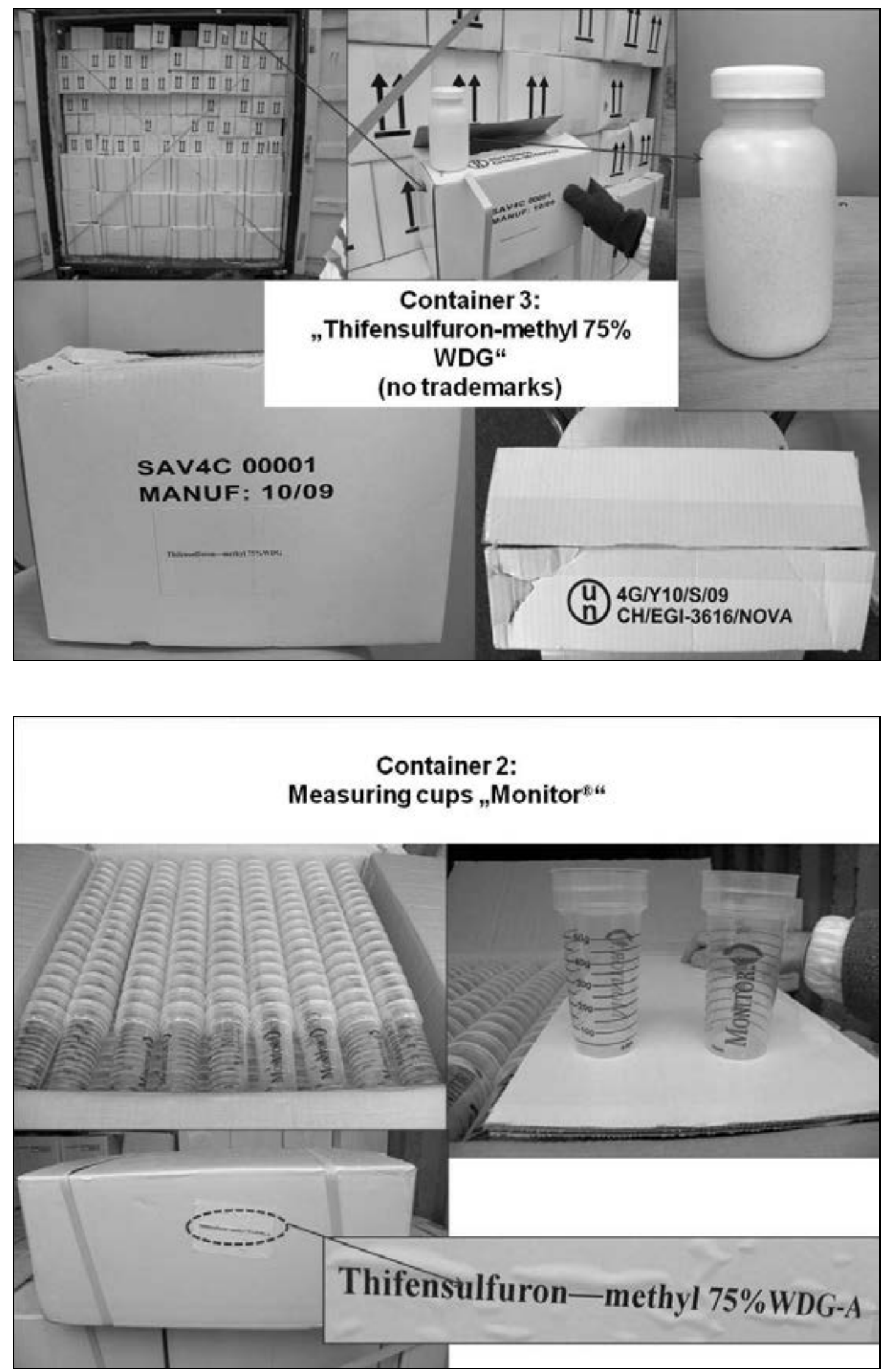


\section{"Emulsifier"-Shipment - Monitor ${ }^{2}$}

- Measuring cups could be seized because of Trademark infringement

- Bottles couldn't be seized (no Trademark on the bottles)

- Boxes were declarated as dangerous goods

- Transshipment to Riga (Latvia)

- Company named as shipper does not exist

- Monitor is a product that is not distributed in Latvia or other contries in Eastern Europe
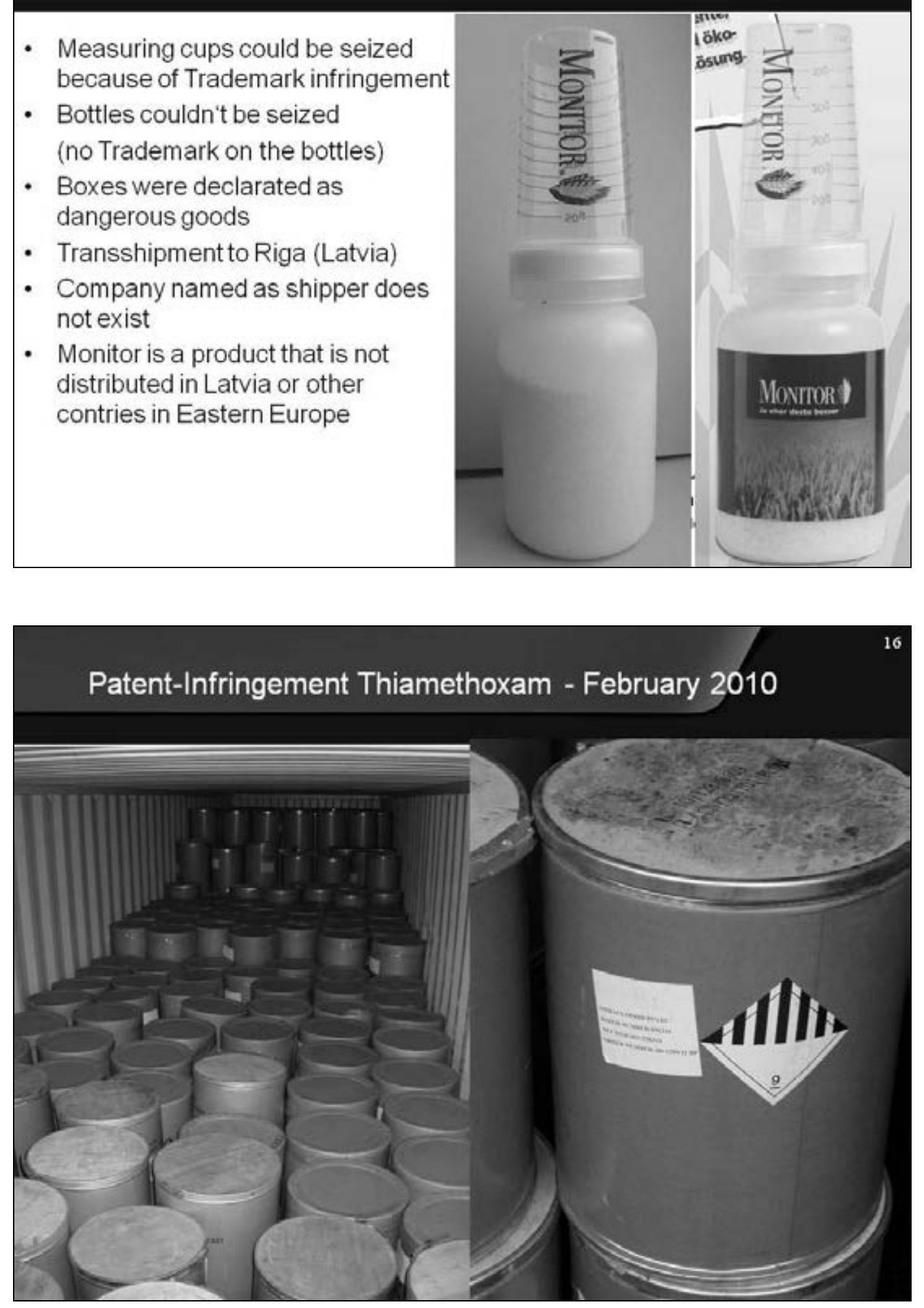

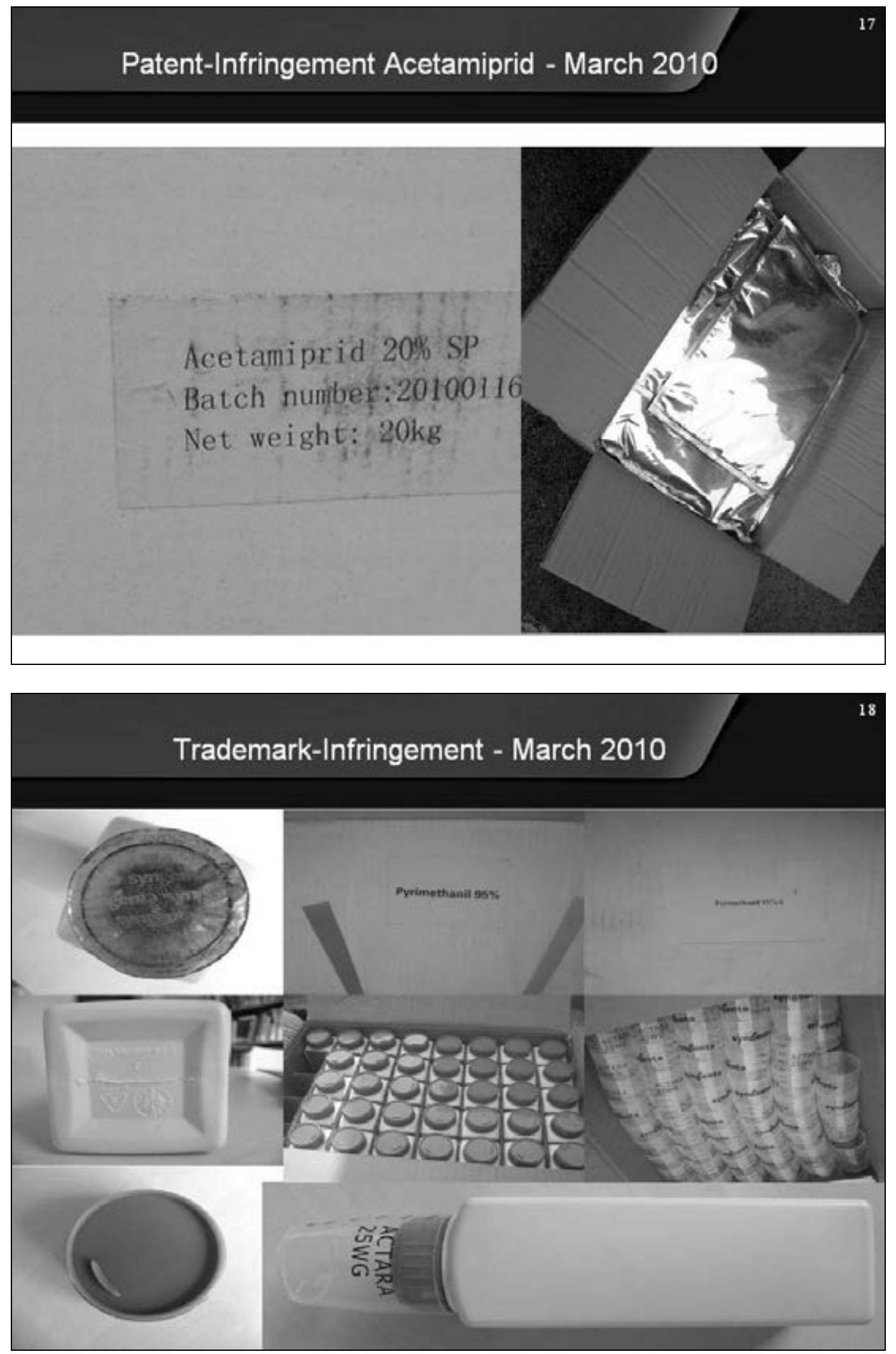

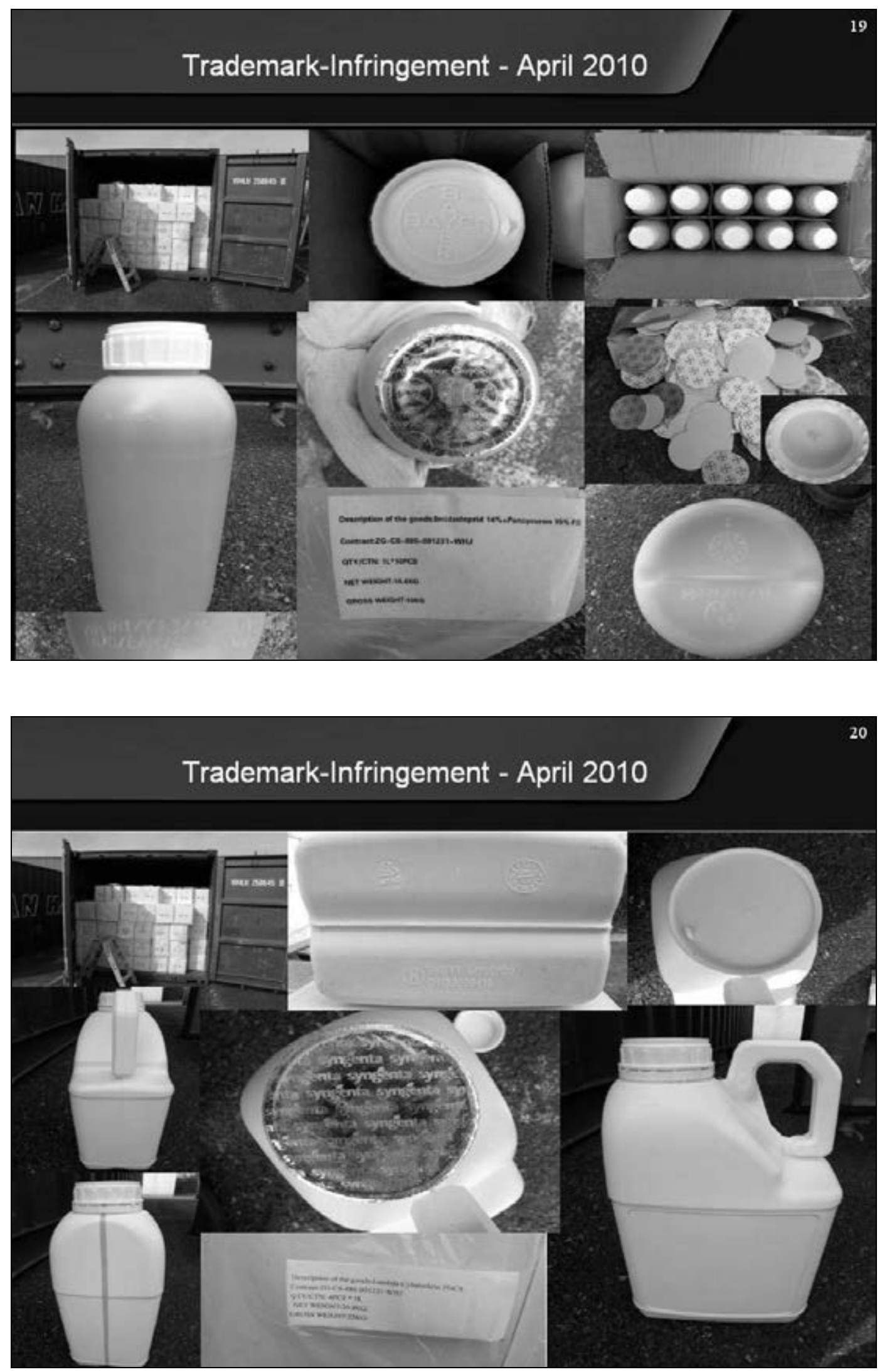


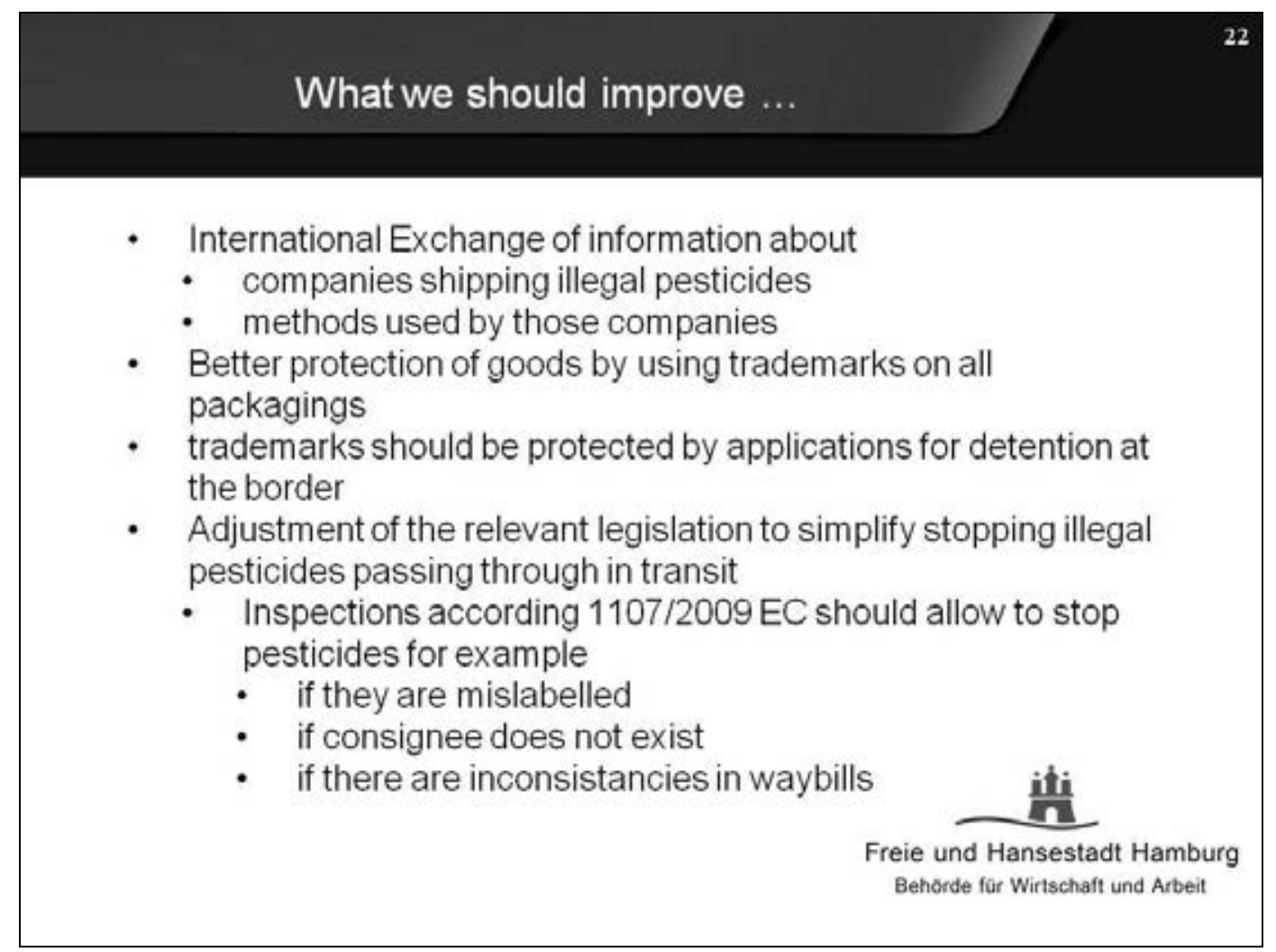




\section{Presentation 2}

USA

Jay Ellenberger

\section{Ensuring Safety \& Integrity of Imported Pesticide Products: \\ The U.S. Approach}

Seminar on Risk Reduction through Prevention, Detection \&

Control of the Illegal International Trade

in Agricultural Pesticides

19 May 2010

Paris, France

Jay Ellenberger

U.S. Environmental Protection Agency

\section{Coordination among Federal Agencies}

- U.S. Department of Homeland Security, Customs \& Border Protection (CBP) has developed the Automated Commercial Environment (ACE) system --

- Electronic receipt of all import data required by all U.S. government agencies.

- Pesticide product data will be integrated within next few years. 


\section{Why is EPA Concerned?}

- EPA is a regulatory agency established to protect the public health and environment

- Recent court case concluded that:

- "The sale of counterfeit and adulterated pesticides ... threatens the public and undermines the federal and state regulatory system intended to ensure the safety and efficacy of pesticides sold in the Unites States."

\section{U.S. Import Requirements}

- Generally, all pesticides imported into the U.S. must be registered by EPA

- Federal Insecticide, Fungicide and Rodenticide Act (FIFRA) Section 17 (c) governs importation of pesticides and devices

- Pesticides \& devices must be properly labeled in accordance with FIFRA \& Title 40 of the Code of Federal Regulations, Section 156

- Every pesticide, device \& technical ingredient used in the manufacture of a pesticide must be produced in an EPA registered establishment

- Requirements on EPA's website to assist compliance. 


\section{Guidance to Importers}

- US EPA websites inform importers (and exporters) about requirements, procedures

- http://www.epa.gov/oppfead1/international/ trade

- http://www.epa.gov/pesticides/about/index.htm

- Direct communications with importers

- Brochures.

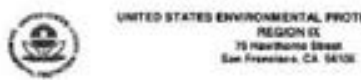 \\ Potect Your Rusiness: Avoid Proticides Imports Violations}

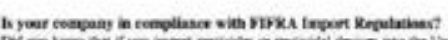

W

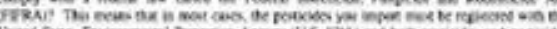

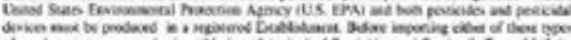
or podmin.

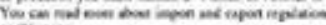
os ais put

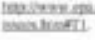

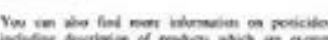

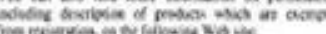

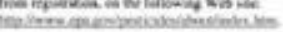

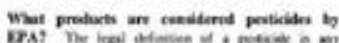

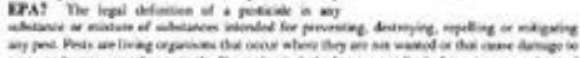

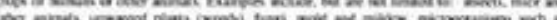

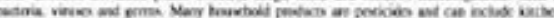

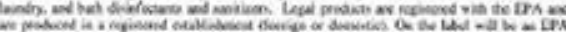
- pala da

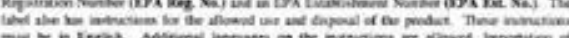

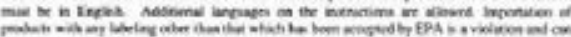

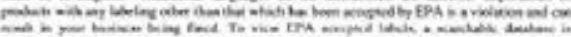

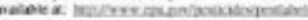

Why dum M I be ceecriaed?

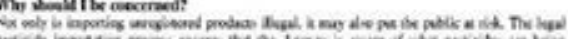

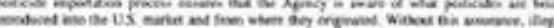

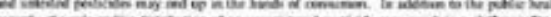

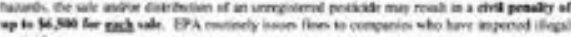

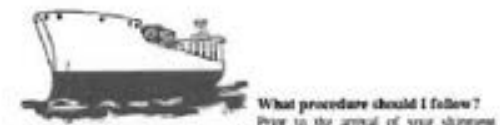

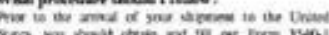

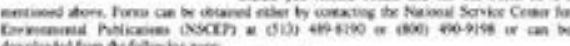

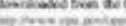

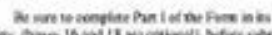

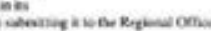

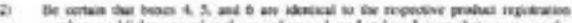

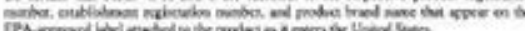

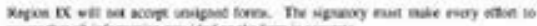

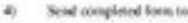

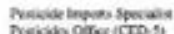

Usivi Rever $\alpha$

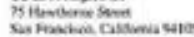

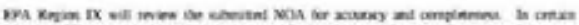

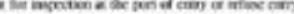

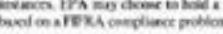

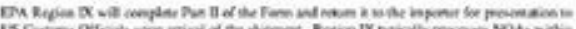

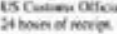

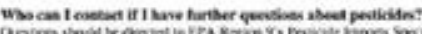

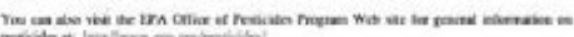

Aipeas. 2006 


\section{The Basic Process}

- Every imported pesticide, device or technical ingredient must have an EPA Notice of Arrival (NOA) form prepared \& submitted to the EPA regional office where the Port of Entry is located - prior to the arrival of the imported product

- EPA reviews NOA \& makes a recommendation to the U.S. Department of Homeland Security/Customs and Border Protection (CBP) to either accept the arrival of the product or deny entry.

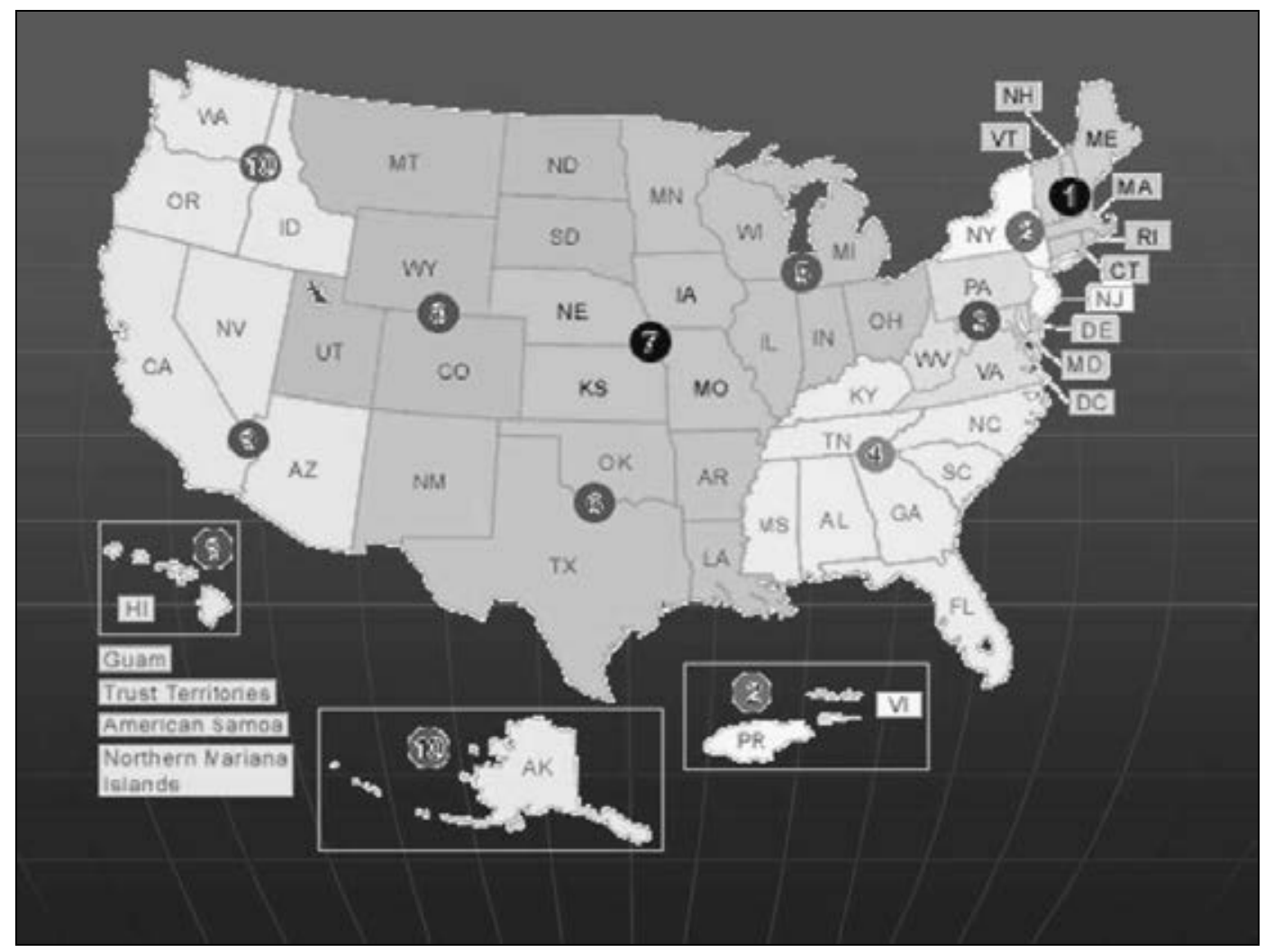




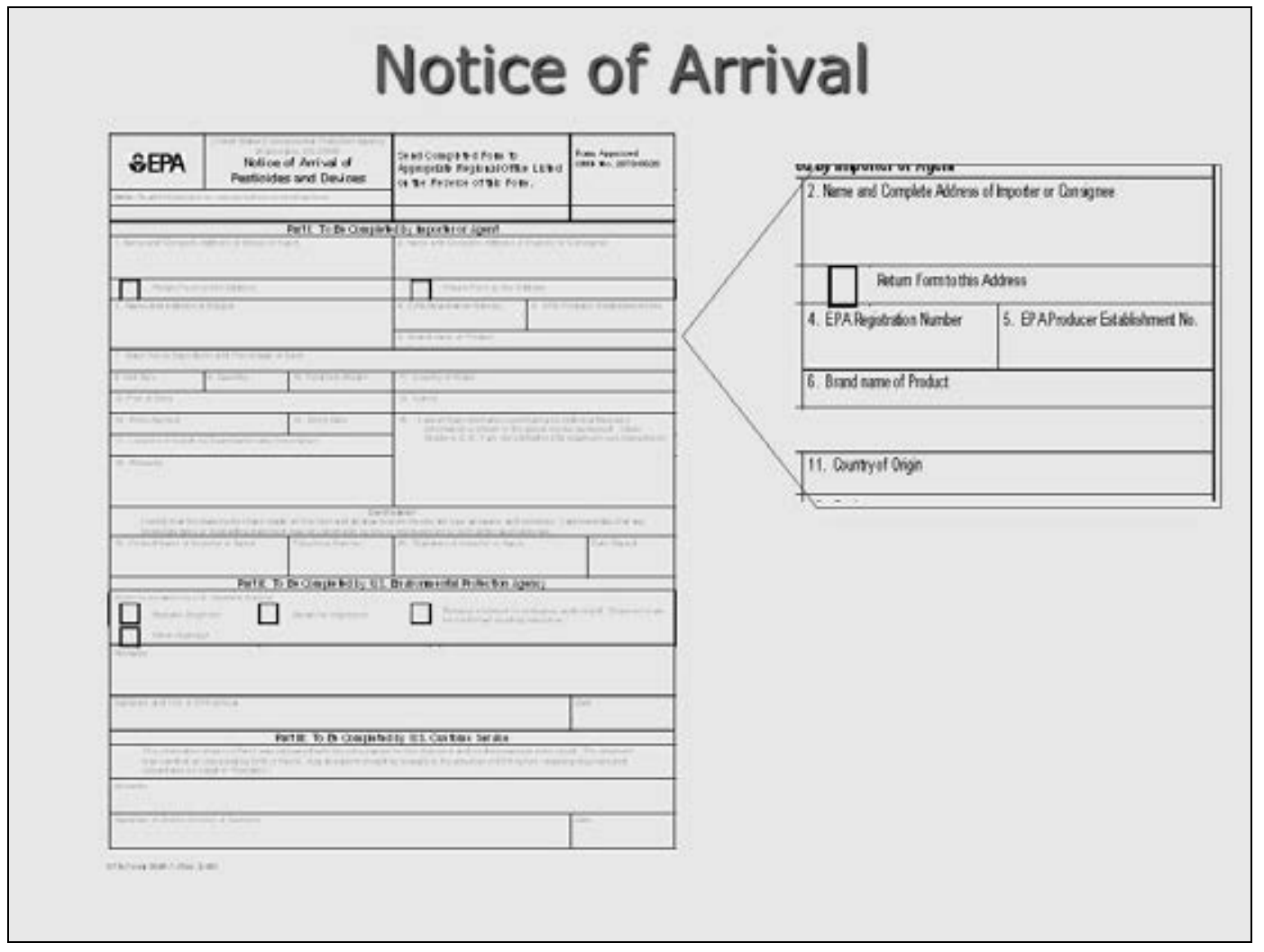

\section{Step-by-Step Process}

1. Importer submits NOA to EPA regional office.

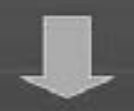

2. EPA reviews and verifies registration.

- If registered, EPA recommends entry to Customs \& Border Patrol (CSB).

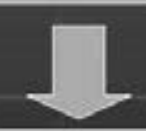

3. Discrepancies? EPA may recommend variety of different responses, depending on the violation:

- CSB deny entry, or

- Detain for inspection, or

- Enter under a Customs Bond and hold for inspection. 


\section{Step-by-Step (cont.)}

\section{Importer submits approved NOA along with other paperwork to CBP.}

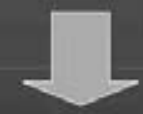

5. Import proceeds.

\section{What is "Illegal Trade" in Pesticides?}

- Counterfeits

- Misrepresented as a registered product

- Case study of Front Line.....

- Unregistered

- Often entry not identified as a pesticide

- NOA usually not filed

- Often not produced in registered production facility or use of an unapproved ingredient or source of ingredient

- Use of unapproved product labeling. 


\section{Illegal Products}

. Unregistered

- Misbranded product label

- Adulterated, different composition

- Counterfeit

- Other violations.

\section{Types of Enforcement Actions}

- Stop Sale and Use Order

- Entry denial

- Administrative complaint with penalty

- Sale/distribution of violative product

- Any movement of product in US territory

- Even if not cleared by Customs

- Example: ship crossing into US territorial waters. 


\section{Enforcement Case 1}

- "Front Line" and "Advantage" products

- Unlawfully imported

- Very specific differences between the counterfeit product and the registered, legitimate versions:

- Discrepancy of lot numbers

- Discrepancy of product labeling

- Retail package not always child-resistant

- Text on the package not always in English only.

- Applicator label for the dog products included the size of the dog in metric units.

\section{Enforcement Case 2}

- Owner of a pesticide distribution company sold counterfeit, misbranded, adulterated and/or mislabeled pesticides to local government municipalities

- Municipalities used counterfeit product to control mosquitoes and the spread of the West Nile virus

- Threat to public (unknown risks from product AND from the potential health effects from the virus)

- Undermined federal and state regulatory systems

- Owner of company

- Sentenced April 21, 2004

- 41 months in prison

- $\$ 45,305$ fine

- 17 counts of violating FIFRA

- 11 counts of trafficking in counterfeit goods. 


\section{Enforcement Case 3}

- Major U.S. chemical company

- Imported a registered pesticide active ingredient, from a non-approved manufacturing facility in another country

- Composition of the active ingredient differed from the composition specified in the Confidential Statement of Formula submitted at the time of registration

- Civil penalty of $\$ 850,000$.

\section{Summary}

- No history or evidence of large scale counterfeit agricultural pesticides in U.S.

- U.S. has a multi-agency comprehensive program for importation of pesticides

- Continuing to make improvements

- U.S. has an effective compliance and enforcement system governing the distribution, sale and use of pesticides. 


\section{Presentation 3}

Australia

Eva Bennet-Jenkins

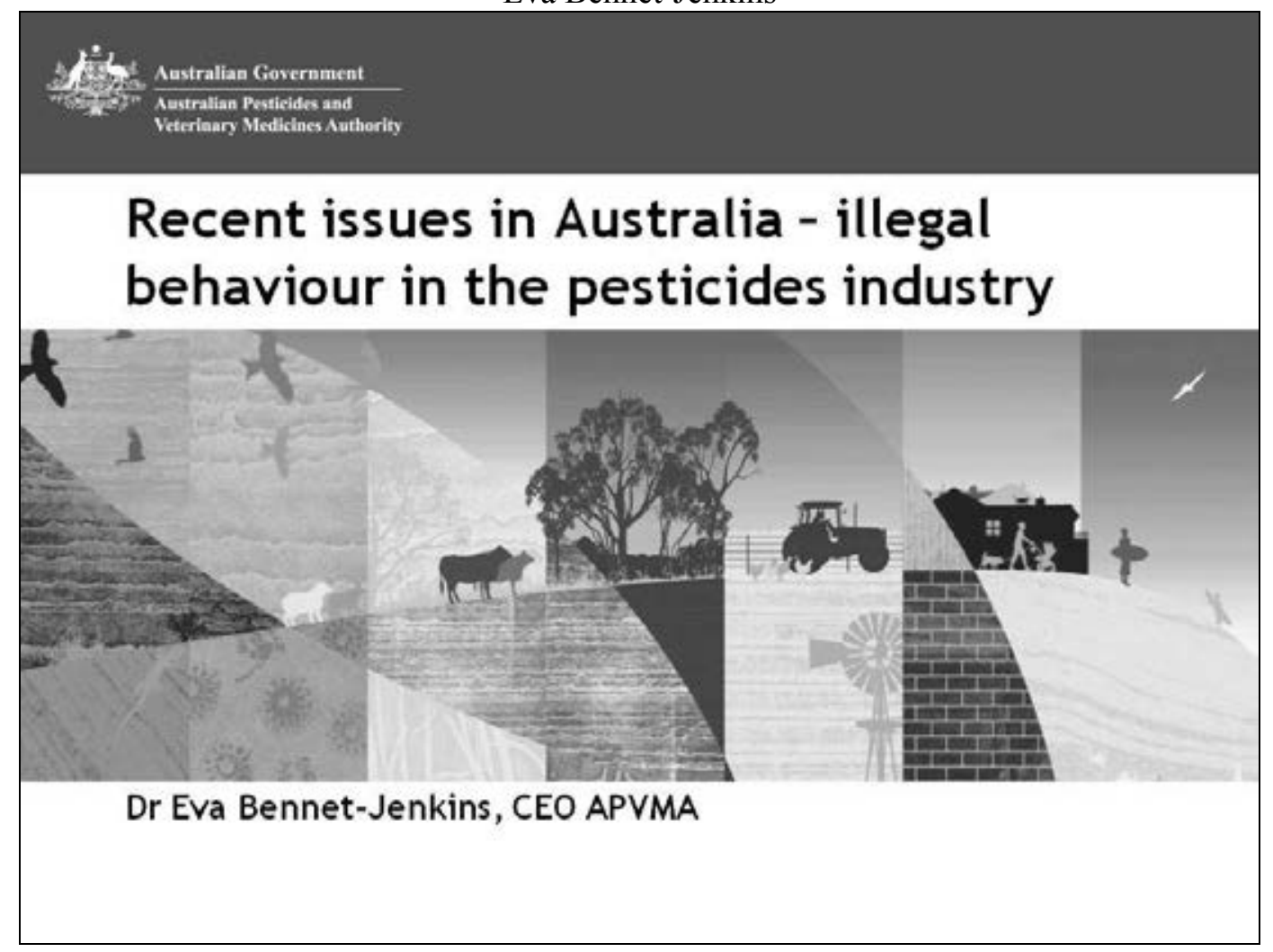

\section{The "Imtrade" Investigation}

- Two sites of manufacture for 28 active constituents relevant to 120 products identified as 'fictitious'

- No mechanism in the legislative framework to undo approval

- Absolute invalidity $v$ Relative invalidity

- APVMA 'self help' unlawful

- Separate criminal offences being considered by the independent federal prosecutor

- Anecdotally 'fraud' increasingly being identified

- Need for legislative change

- Need to strengthen international relationships 


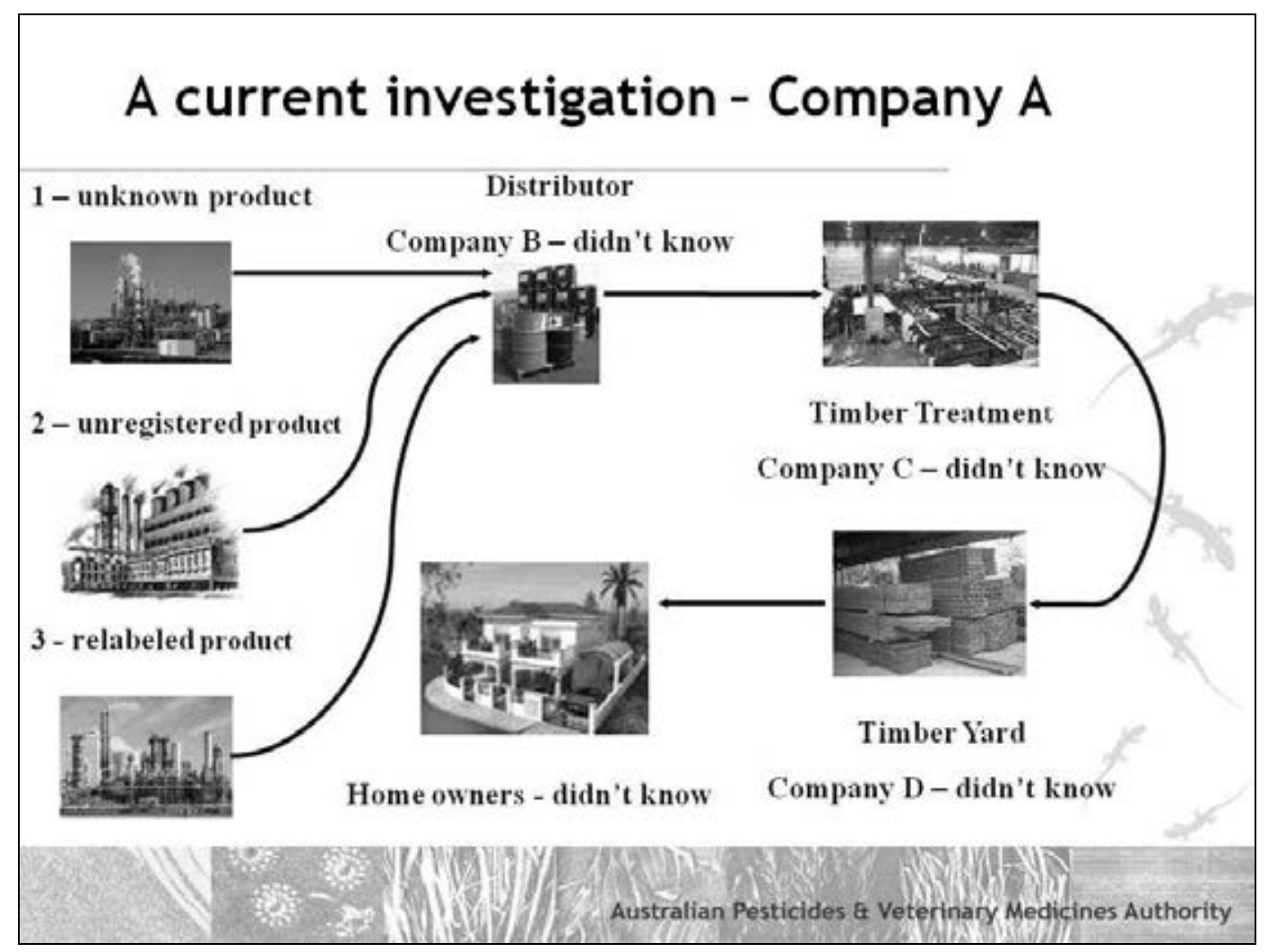

\section{APVMA regulatory posture}

- APVMA moving to redefine and publicly communicate overall regulatory posture

- Will be publishing a new Compliance and Enforcement policy

- Main effort is to bring people into compliance

- Secondary consideration - what sanction, if any, should apply?

- APVMA has enhanced 'field' monitoring regime inspections, visits, audits \& investigations

- Government reviews - time to seek a new compliance toolkit

- More options, stronger penalties

- Recognise and integrate good stewardship

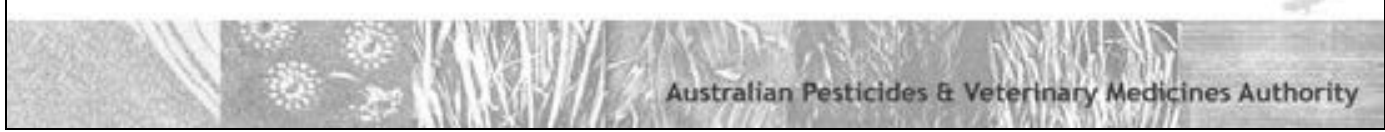




\section{APVMA Vision}

- 'To be recognised nationally and internationally as a best practice regulator of pesticides and veterinary medicines that has the respect and confidence of governments, the community, the rural sector, chemical users and the chemicals industry'

\section{Questions?}

Further information

Dr Eva Bennet-Jenkins

Eva.Bennet-Jenkins@apvma.gov.au

or

Neville Matthew

Neville.Matthew@apvma.gov.au 
Presentation 4

People's Republic of China

Gu Baogen

\section{Crack Down Illegal Trade to Promote} Sustainable Development of the Pesticide

International Trade

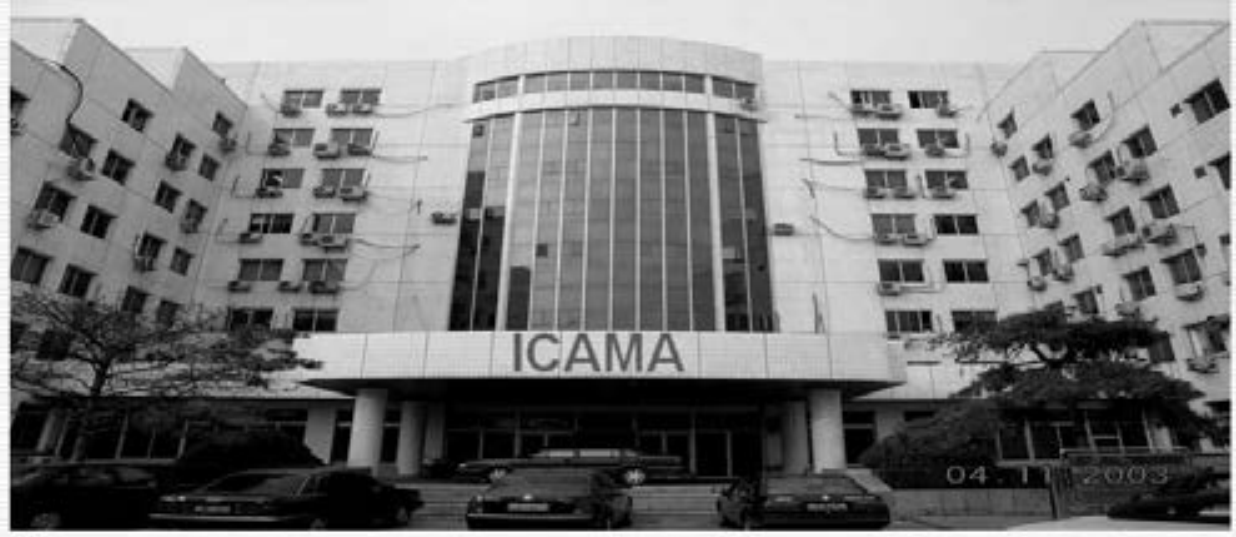

$O E C D$

Gu Baogen ICAMA May. 2010

\section{Outline}

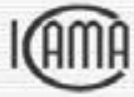

- Part I Introduction to Pesticide Production and Export in China

Patr II Overview of Pesticide Management in

\section{China}

Part III Situation of Illegal International Pesticide

Trade and Their Causes

- Part IV Suggestions 


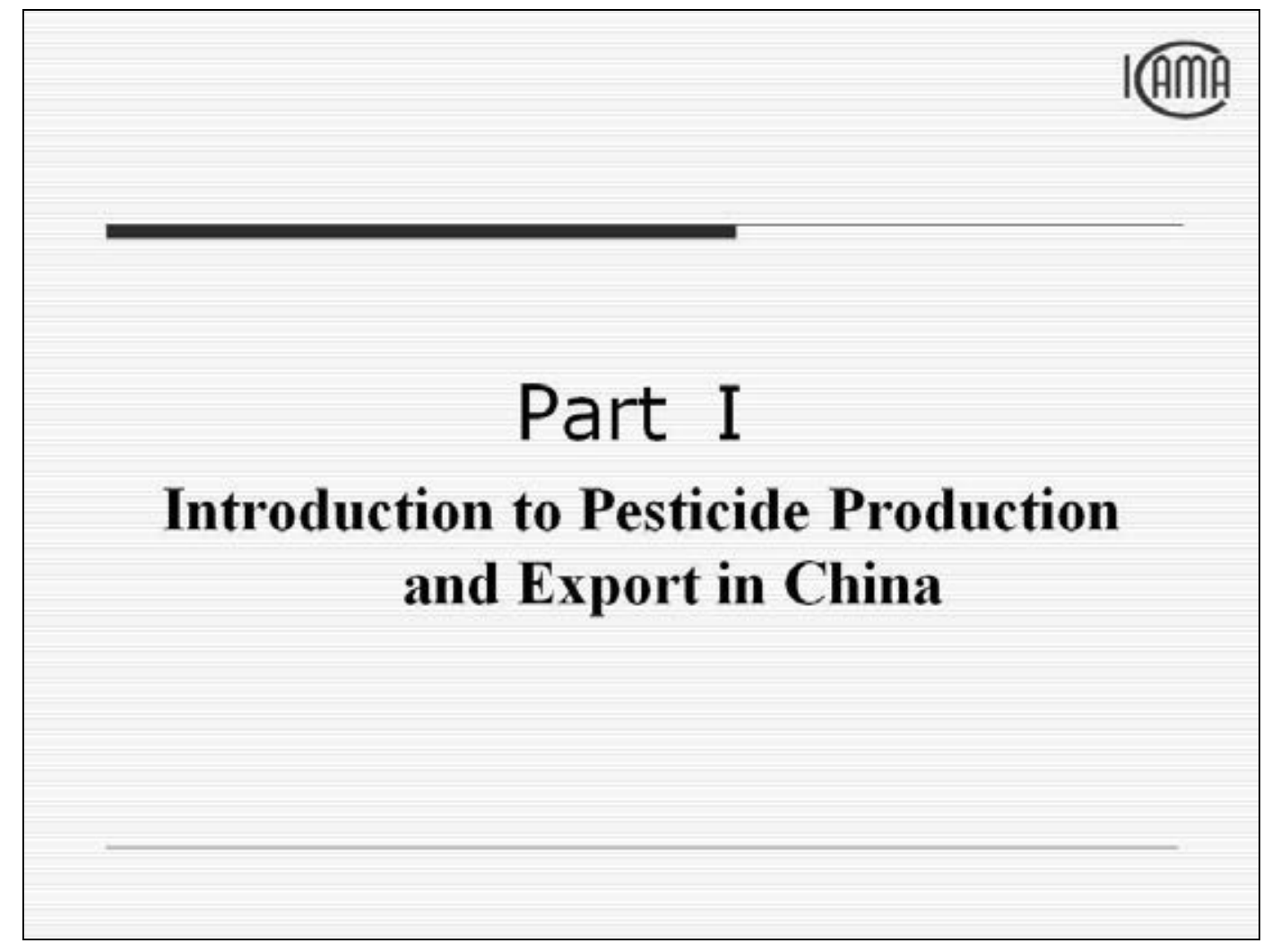

\section{Introduction to Pesticide Production and Export in China}

Since the early 1990 s, a change has occurred to the world's pesticide production. Pesticide production has been gradually shifted from developed countries to developing countries due to the increasing environmental pressure and labor costs.

- China's pesticide industry has been developing rapidly. A complete system of production of technicals, formulation and of intermediates has been established. 
ENV/JM/MONO(2011)6
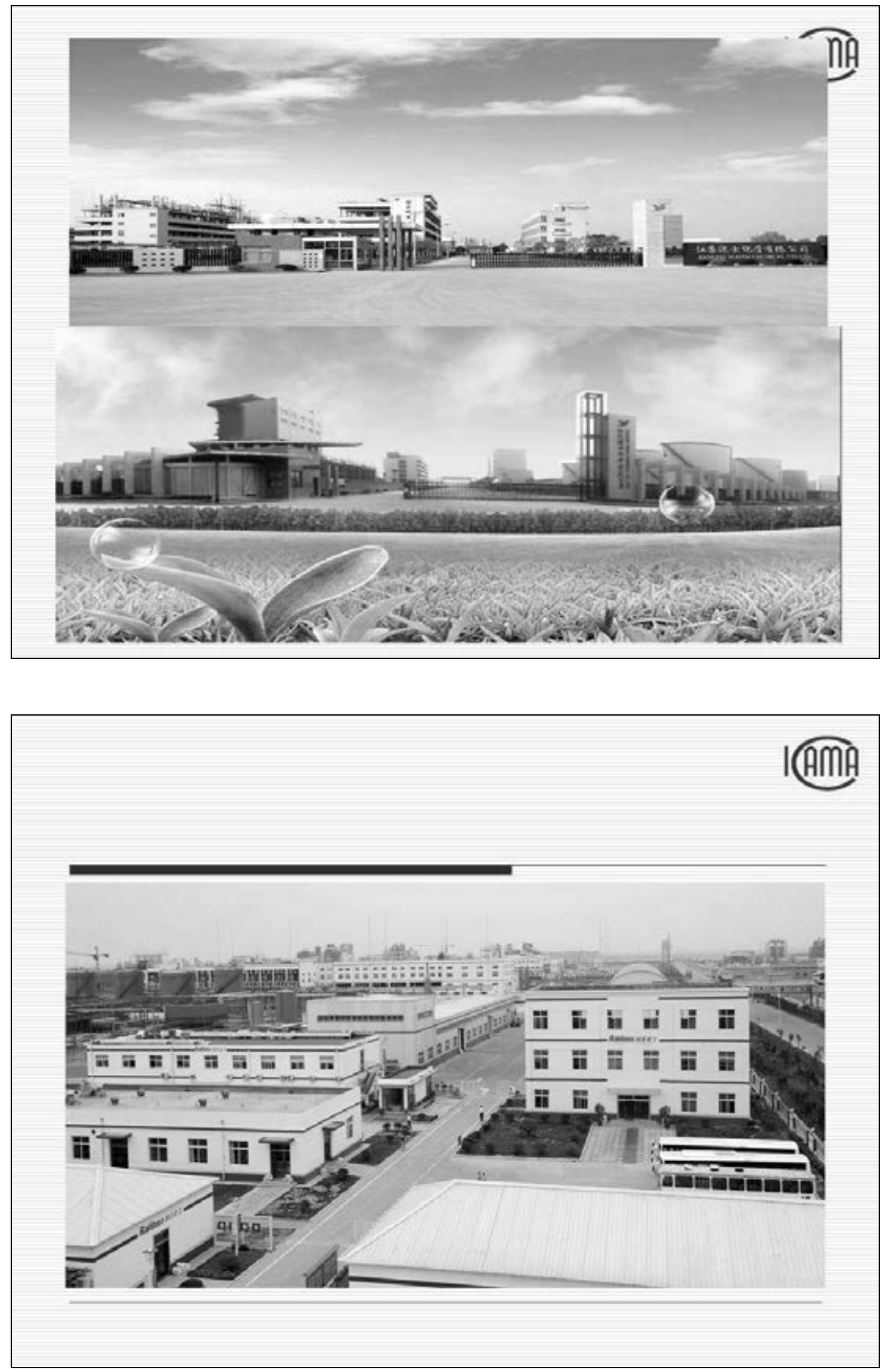


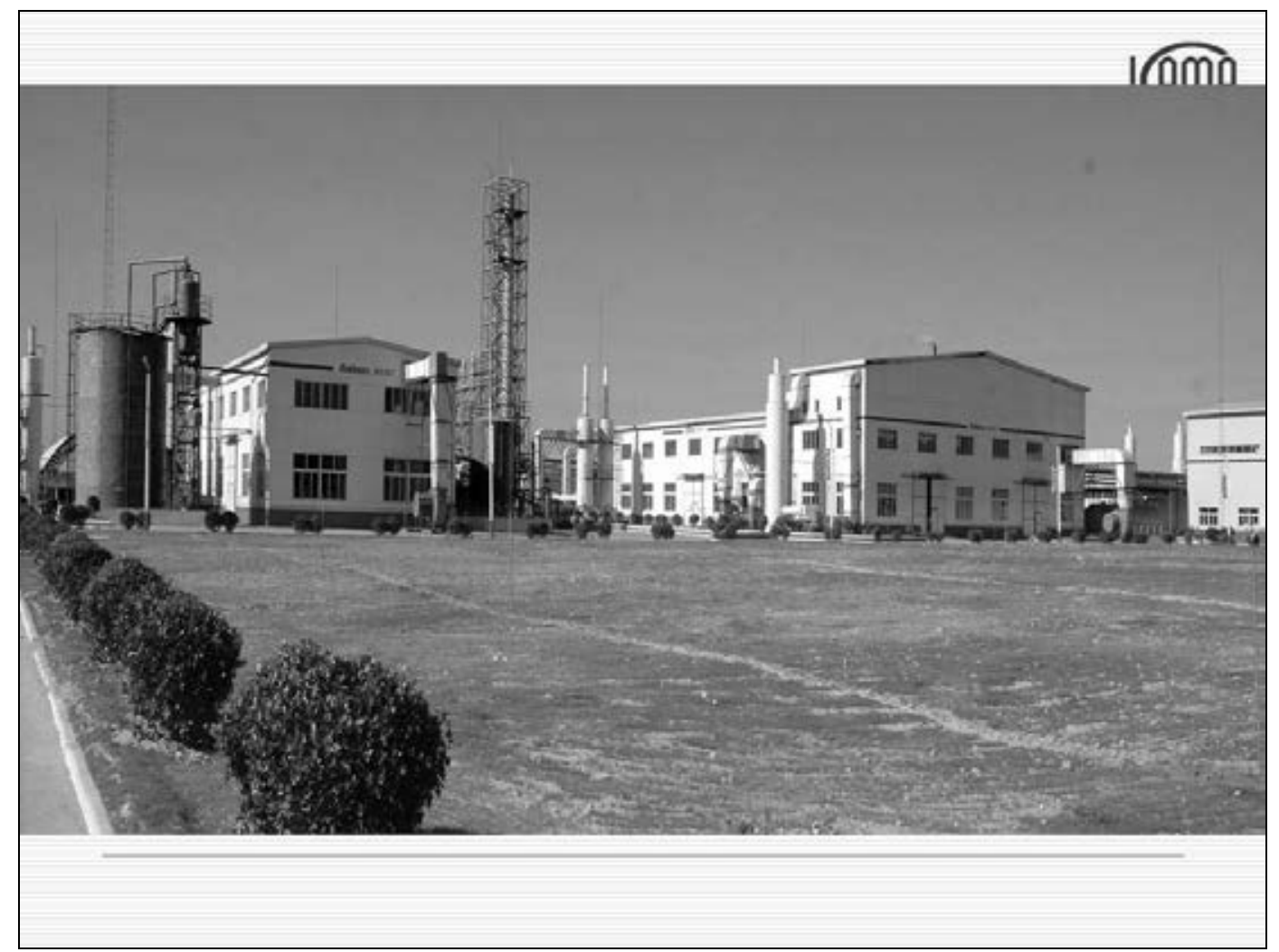

\section{Introduction to Pesticide Production and Export in China}

- Production:

- Currently, there are about 2,400 pesticide manufacturers or formulators, producing over 600 active ingredients.

- In 2009, 26,000 pesticide products registered, 2.26 million tones (technical) produced 


\section{Introduction to Pesticide Production and Export in China}

- Export:

more than 400 pesticides were exported to 162 countries and regions

export amount reached to 1.04 million tones in 2009 .

\section{Export:}

\begin{tabular}{|l|l|l|}
\hline regions & amount(ton) & proportion \\
\hline Asia & 399,300 & $38.3 \%$ \\
\hline South America & 246,400 & $23.6 \%$ \\
\hline North America & 146,800 & $14.1 \%$ \\
\hline Africa & 123,100 & $11.8 \%$ \\
\hline Europe & 92,800 & $8.9 \%$ \\
\hline Oceania & & $3.3 \%$ \\
\hline
\end{tabular}




\section{Introduction to Pesticide Production and Export in China}

China has gradually become a key pesticide producer and supplier in the world,

warmly welcome by farmers worldwide, especially those in the Third World because of good quality and lower price.

\section{Introduction to Pesticide Production and Export in China}

Their prices are normally $1 / 3---1 / 10$ of multinational companies

- the costs of global agricultural production could be reduced by billions of dollars.

- In this regard, China and India are contributing greatly to the world's pesticide industry and agriculture while sacrificing the health of human, animals, and its environment. 
ENV/JM/MONO(2011)6
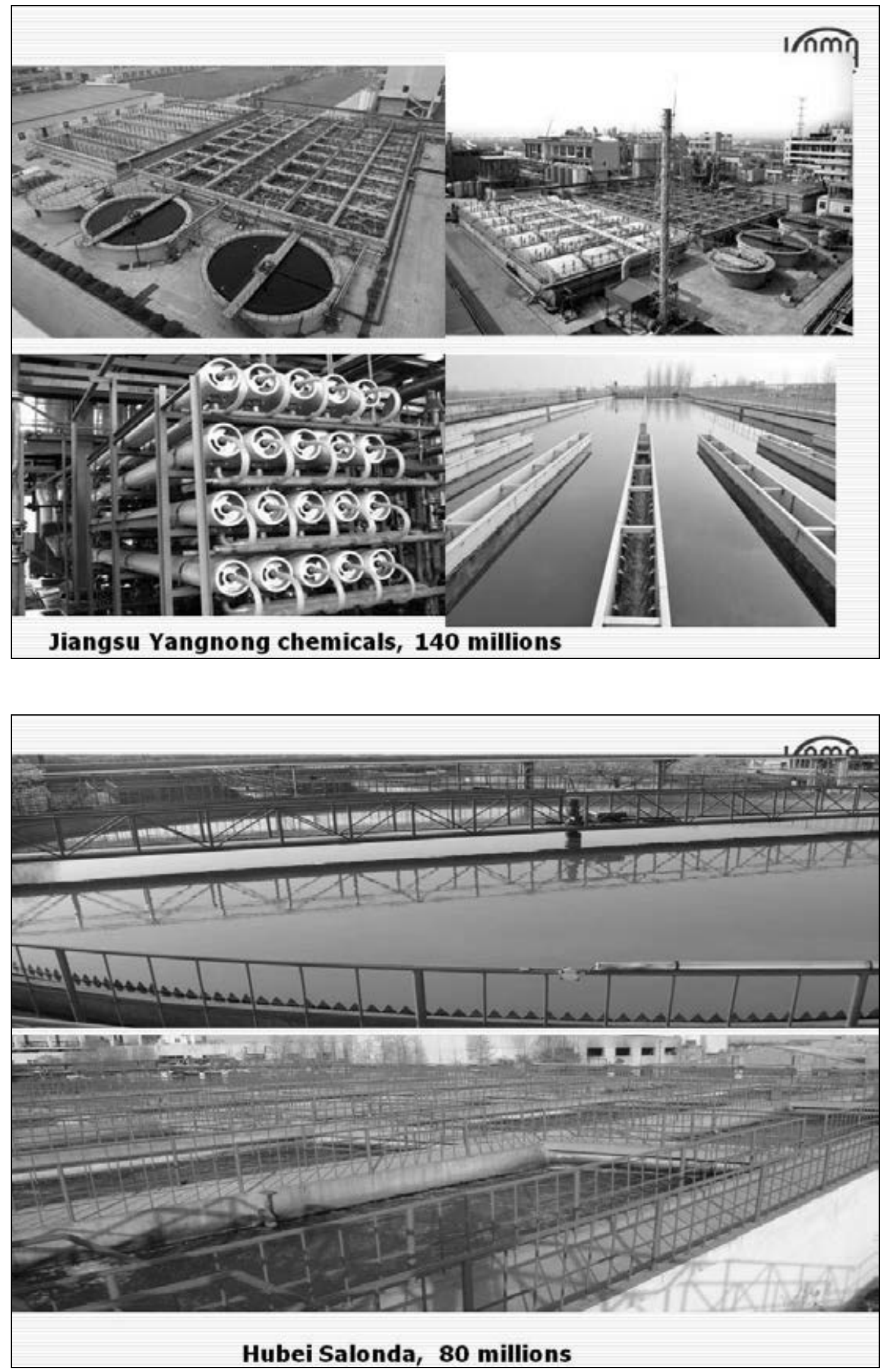

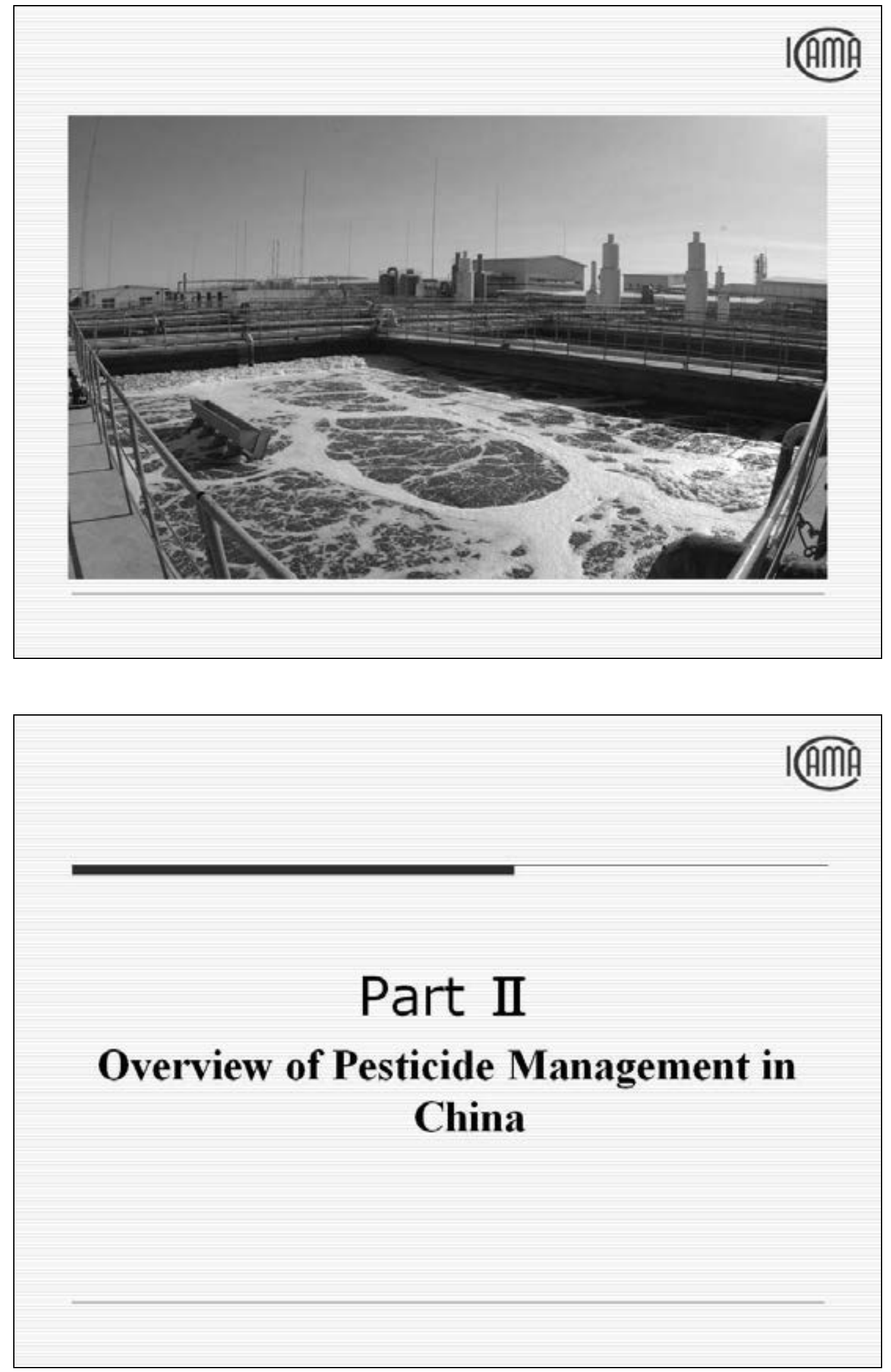


\section{Overview of Pesticide Mangement in China}

\section{Pesticide Registration System}

\section{Pesticide Quality Control}

\section{Measures for the Control of Pesticide Import \& Export}

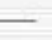




\section{Overview of Pesticide Mangement in China}

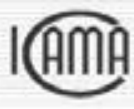

\section{Pesticide Registration System}

\section{Pesticide Quality Control}

\section{Measures for the Control of Pesticide Import \& Export}

\section{Pesticide Quality Control}

a. Pesticide Quality Standards

- China's pesticide quality standards include the national, industry and enterprise standards. All the standards for major pesticide products equal or exceed FAO specifications .

- 252 national standards and industry standards

- 25000 enterprise standards for pesticide products. 


\section{Pesticide Quality Control}

b. Supervision and Inspection of Pesticide Quality

- MOA \& SOIC are responsible for supervision and control of the pesticide market in China

- A anti-counterfeiting office established in MOA to launch campaigns against counterfeit means of agricultural production, especially pesticides,

\section{Pesticide Quality Control}

b. Supervision and Inspection of Pesticide Quality

- Each year, more than 20,000 pesticide samples are sampled and tested,

- Dozens of cases of fake and inferior pesticides are investigated and heavily punished.

- the qualification rate of almost all pesticide products in large quantities has reached $100 \%$ in China. 


\section{Pesticide Quality Control}

c. Enterprise Quality Assurance.

- Quality assurance system has been established in all pesticide manufacturers and formulators in China, most of which have passed the ISO9000 quality accreditation system certification.

- Most newly installed equipment adopts advanced DCS automatic system in production, the whole process of synthesis is controlled by computers,

- the production techniques and measures are optimized to improve the quality of products. 
ENV/JM/MONO(2011)6
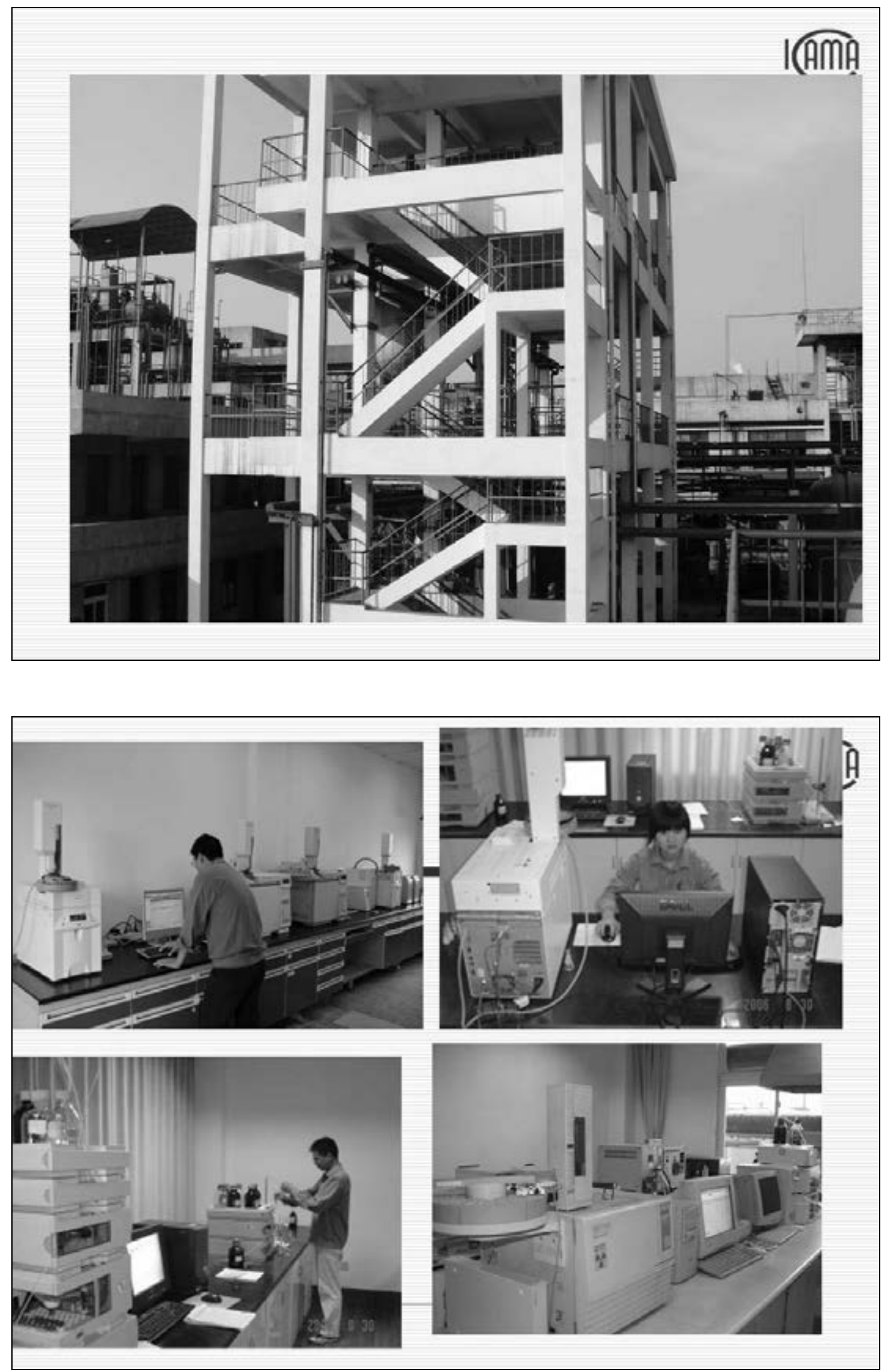
ENV/JM/MONO(2011)6
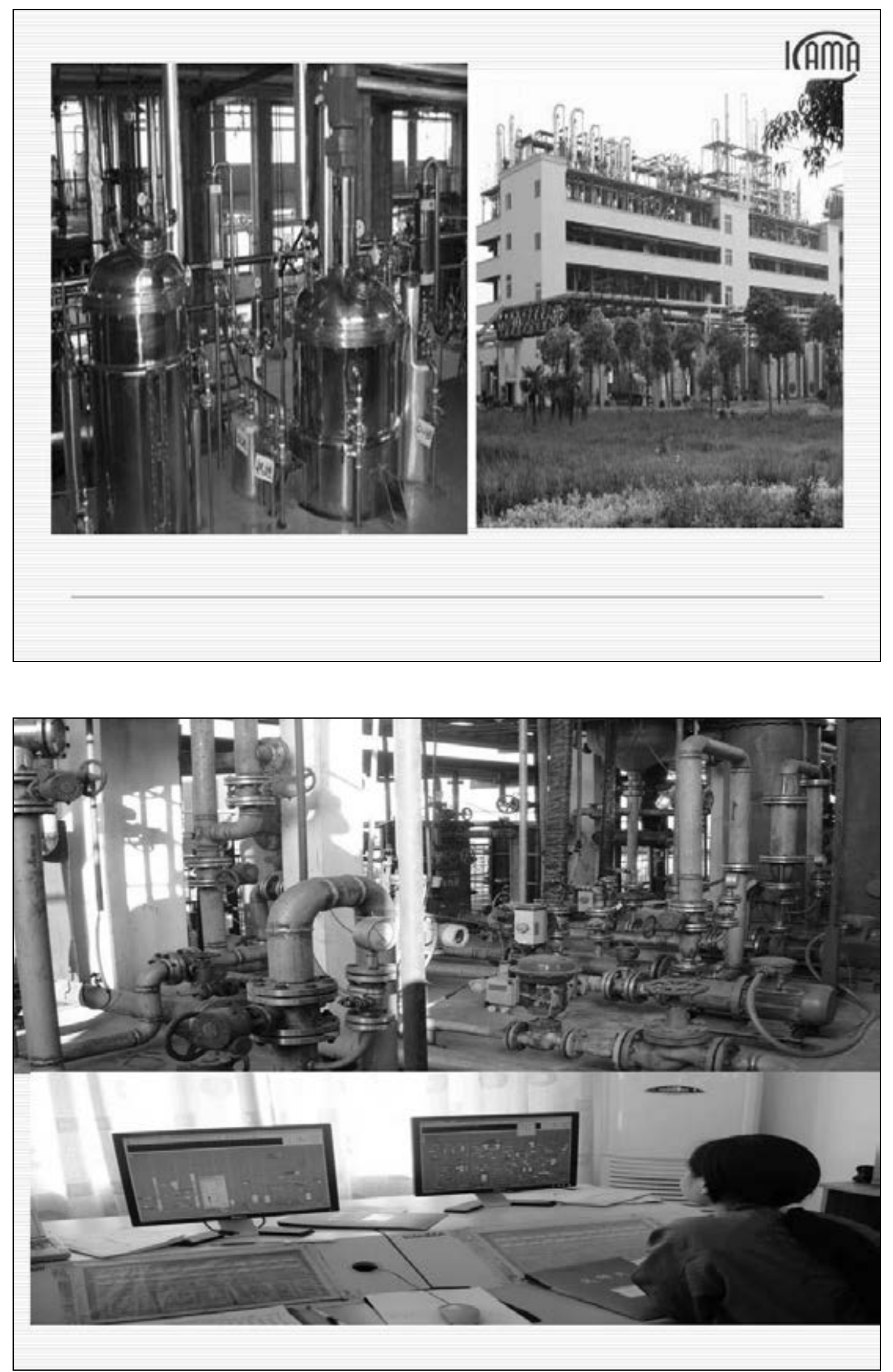
ENV/JM/MONO(2011)6
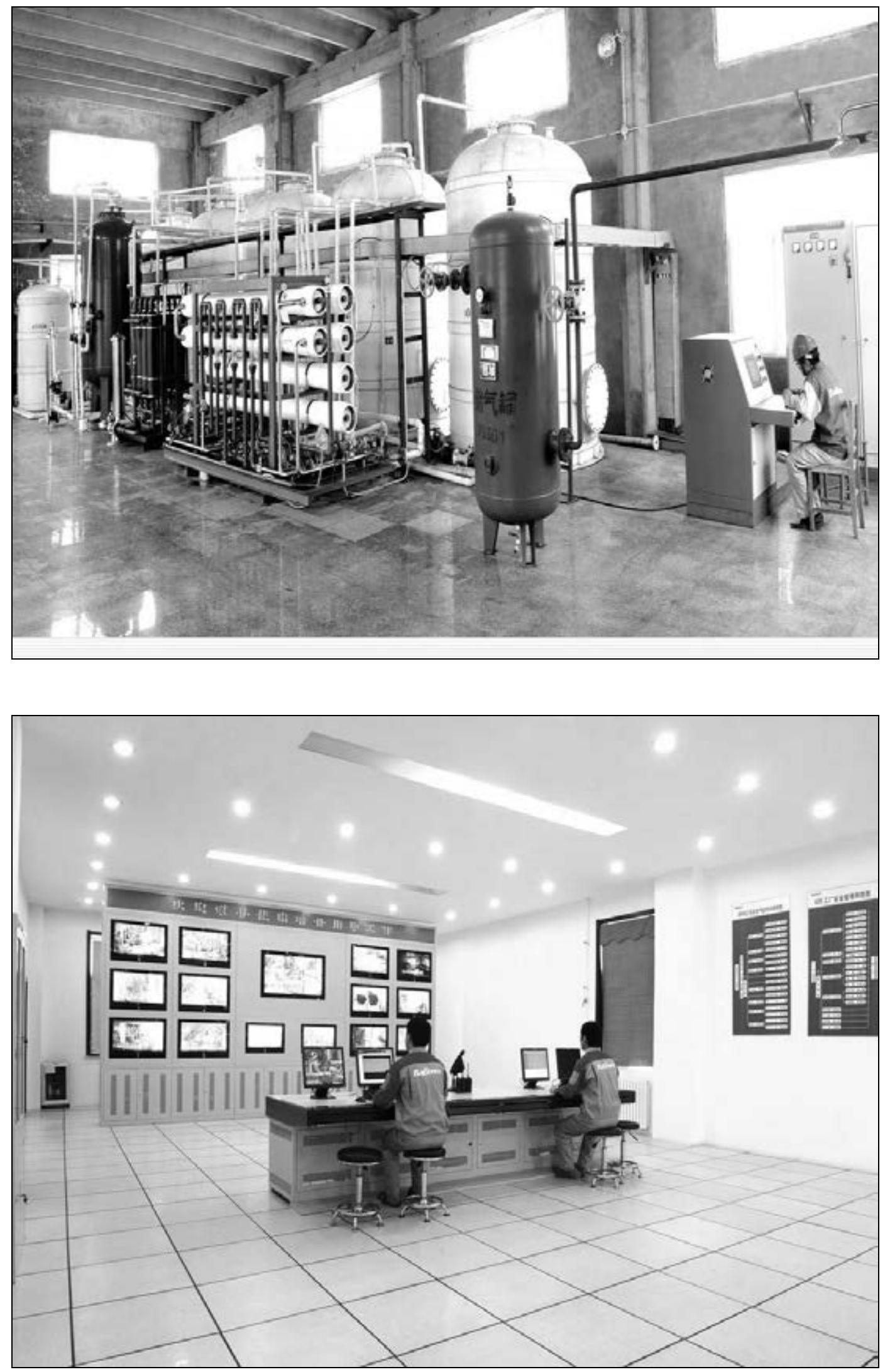


\section{Overview of Pesticide Mangement in China}

\section{Pesticide Registration System}

\section{Pesticide Quality Control}

\section{Measures for the Control of Pesticide Import \& Export}

3. Measures for the control of pesticide import and export

a. Import or Export Registration Certificate for Pesticides

- In 1999, MOA and Customs jointly issued the Notice on the Use of Import or Export Registration Certificate for Pesticides.

- The Notice has enabled us to effectively prevent and crack down on import and export of unregistered, counterfeit and inferior pesticides 


\section{Measures for the control of pesticide import and export}

ICAMA issues certificates for each shipment of pesticides exported,

Certificate is only issued to registered pesticides.

customs check the certificates

\section{Steps of import /export} control

1.Importer/expoter apply for certificate in ICAMA

2.ICAMA check the situation of registration of the product

3. ICAMA approve the import/export issuing the certificate

4.Importer/exporter show the certificate to customs for entry.

Custom has a name list

Information exchange between ICAMA and custom electronically in near future. 


\section{Measures for the control of pesticide import \\ and export \\ b. Certificate for Pesticides Registered in China}

- ICAMA issues the Certificate for Pesticides Registered in China, including the Certificate for Pesticide Registration (Certificate of Free Sale) and the Certificate for Composition of Pesticide technical materials and formulations, to help importing countries find out the registration status and technical data of the pesticides that they are going to be imported.

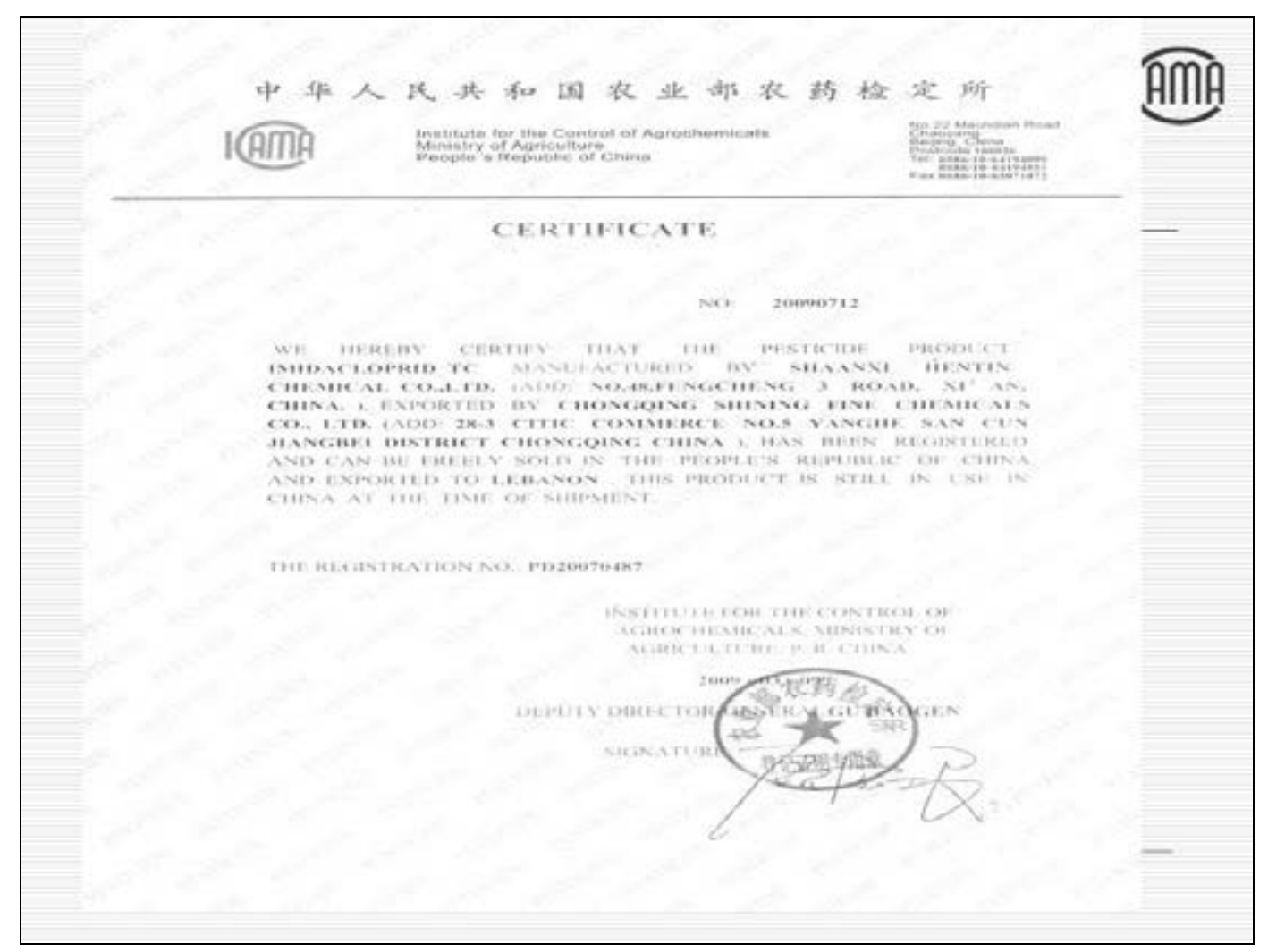


3. Measures for the control of pesticide import

\section{and export}

c. Exchanges and Cooperation in International Trade Management

- Signing cooperative agreements (MOU) and establishing mechanism for joint work with Pakistan, and Thailand etc.

- Verifying information and exchanging documents with the relevant authorities in some countries such as Pakistan, Thailand, Vietnam, Indonesia, South Africa, Kenya, and Lebanon, etc.

3. Measures for the control of pesticide import and export

c. Exchanges and Cooperation in International Trade Management

- With Thailand: 45 Chinese enterprises

- With Lebanon: 300 pesticide registration and 14 certificate of free sale

With Pakistan: 50 Chinese enterprises and 100 products 
3. Measures for the control of pesticide import

\section{and export}

d. Cracking down on illegal trade and strengthening quality monitoring

- In 2009, dealt with two cases involving forgery of the Import or Export Registration Certificate for Pesticides

- In addition, the General Administration of Quality Supervision, Inspection and Quarantine carried out random quality checks at the ports of entry/departure

\section{Part III}

Situation of Illegal International Pesticide Trade and Their Causes 


\section{Situation of Illegal International Pesticide Trade and Their Causes}

\section{Current Situation of Illegal International Pesticides Trade}

2. Causes of Illegal International Pesticide Trade

\section{Current Situation of Illegal International} Pesticides Trade

a. Import and Export of Illegal Pesticides.

- In many cases, the illegal pesticides are exported in names of non-dangerous chemicals or fake Import or Export Registration Certificate for Pesticides, and it's very difficult for customs to inspect each batch of pesticides exported.

- For example, the case founded by Croplife in Hungary.

- However, they consists of very small proportion of whole trade, much less than $0.1 \%$,

2009, 70993 shipments, few illegal cases found or reported. 


\section{Current Situation of Illegal International Pesticides Trade}

b. Trade of Counterfeit and Inferior Products.

- We still have been informed the illegal trade cases by the authorities of importing countries.

- It is found that most counterfeit and inferior products are produced by local importers in importing countries.

\section{Current Situation of Illegal International Pesticides Trade}

c. Smuggling of Pesticides

smuggling is common between countries where there is no proper pesticides import/export management measures implied by customs.

- Many new pesticide products of multinational companies were smuggled into China, and some Chinese products into neighboring countries. But now it hardly happens in China, because of present strict control of pesticide import and export. 


\section{Situation of Illegal International Pesticide}

\section{Trade and Their Causes}

\section{Current Situation of Illegal International Pesticides Trade}

\section{Causes of Illegal International Pesticide Trade}

\section{Causes of Illegal International}

\section{Pesticide Trade}

a. Lack of the control of pesticide import and export in some countries.

- Most countries demand that pesticides to be imported be subject to registration and custom surveilance,

- they place few or no limitations on pesticides export, regardless of the fact that they are prohibited to be used.

As a result, it's difficult to hold back illegal pesticide exports and counterfeits in an effective way globally. 


\section{Causes of Illegal International Pesticide Trade}

b. Scarcity of effective communication and cooperation between exporting and importing parties.

There is no proper communication and cooperation on management of import and export of pesticide.

\section{Causes of Illegal International Pesticide Trade}

c. Weak ability to crack down on counterfeits and inspect the market.

there is no or less capacity to enforce law and inspect the quality of pesticides in some countries, especially developing countries, because of lack of human resource, adequate testing facilities and technology,

- illegal trade, and counterfeit and inferior products could not be properly controlled. 


\section{Causes of Illegal International Pesticide Trade}

d. Complexity of Illegal trade and its control.

- It is very difficult to investigate and collect evidence,

it is still difficult to impose punishment, even though the evidence has been found.

- the global market share of pesticide has been changed by the increase in Chinese and Indian exports. In some places, the use of certain administrative measures and techniques to protect the already gained market shares and interests has made illegal international trade more complex.

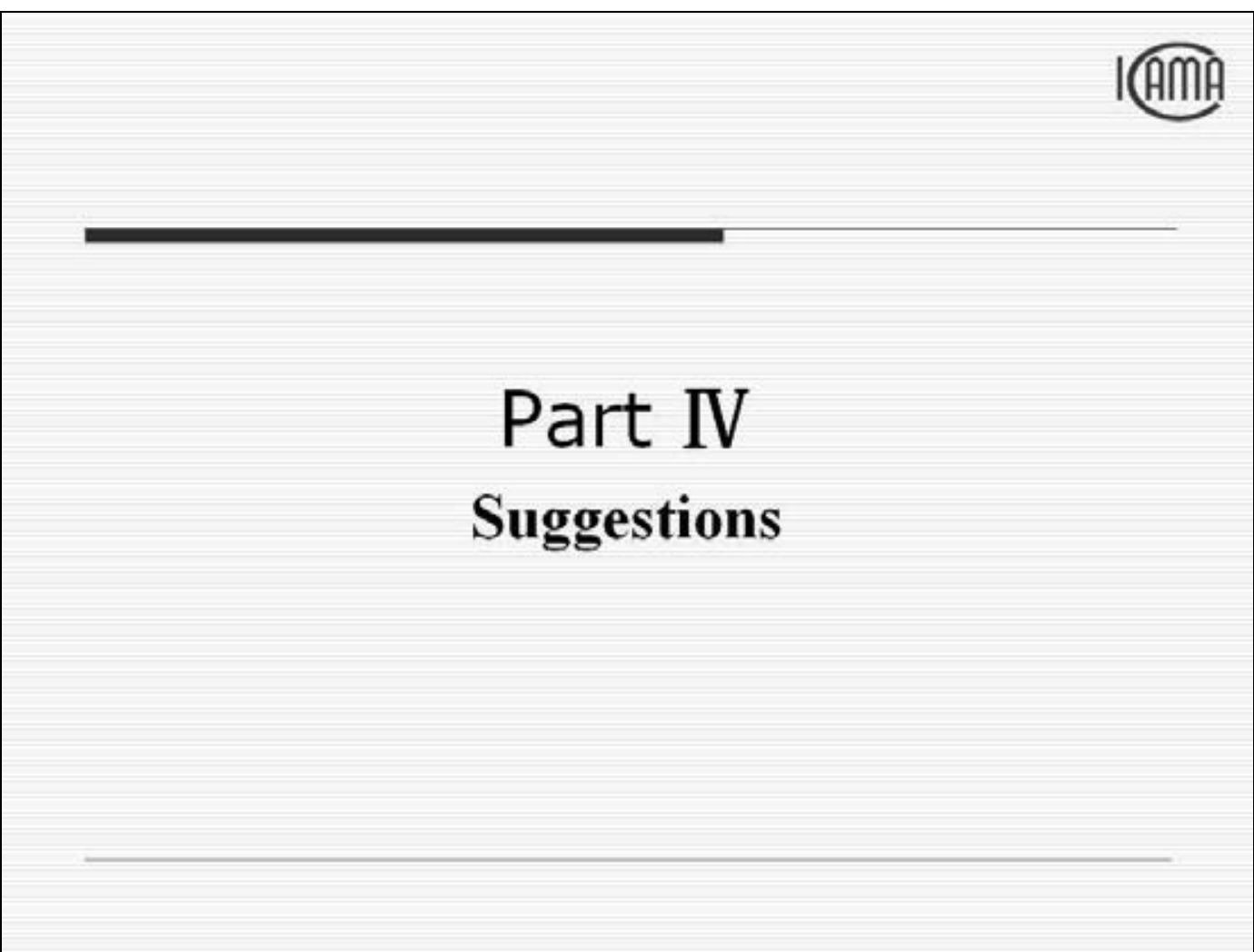




\section{Suggestions}

1. Establish sound system for controlling import and export of pesticides in all countries.

2. Strengthen International Cooperation.

3. Work together to monitor and control the quality of pesticide imports and exports.

4. Institute a long term scheme for cracking down on illegal trade.

1. Establish sound system for controlling import and export of pesticides in all countries.

system like Chinese one for control of pesticide imports and exports should be established

all custom will check each shipment of importing and exporting of pesticides.

- importing countries should ask authority of exporting countries to provide registration certificates to them.

- This system is the precondition of cracking down on illegal international trade. 
2. Strengthen International Cooperation.

- Intergovernmental exchanges and cooperation should be strengthened:

--signing cooperation agreements,

--establishing work teams or technical teams,

--exchanging pesticide registration information

--jointly launching investigations and campaigns against counterfeit products.

3. Work together to monitor and control the quality of pesticide imports and exports.

Both importing and exporting countries should take actions to ensure the quality of pesticide quality.

- ICAMA could provide all countries with thirdparty quality inspection, by way of signing multilateral or bilateral agreement, to ensure the quality of pesticide imports and exports and tackle the problems of counterfeit and inferior pesticides. 
4. Institute a long term scheme for cracking

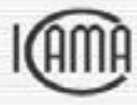
down on illegal trade.

Firstly, sound system of pesticide import and export management;

- Secondly, besides cracking down the illegal trade, legal trade should be promoted;

- Thirdly, an information platform could be established;

- Fourthly, global free trade of pesticides should be continually promoted, and any trade protection and technical barriers must be rejected.

\section{Hope}

As China now is one of the leading pesticide manufacturing countries in the world, we feel obliged to work together with other countries to crack down on illegal import and export of counterfeit and inferior pesticides and make the order of international pesticide trade fairer and more equitable. At the same time, we hope to further strengthen cooperation with other countries to solve all the problems existing in pesticide import and export. 
ENV/JM/MONO(2011)6

THANK YOU 


\section{Presentation 5}

Brazil

Marcelo Bressan
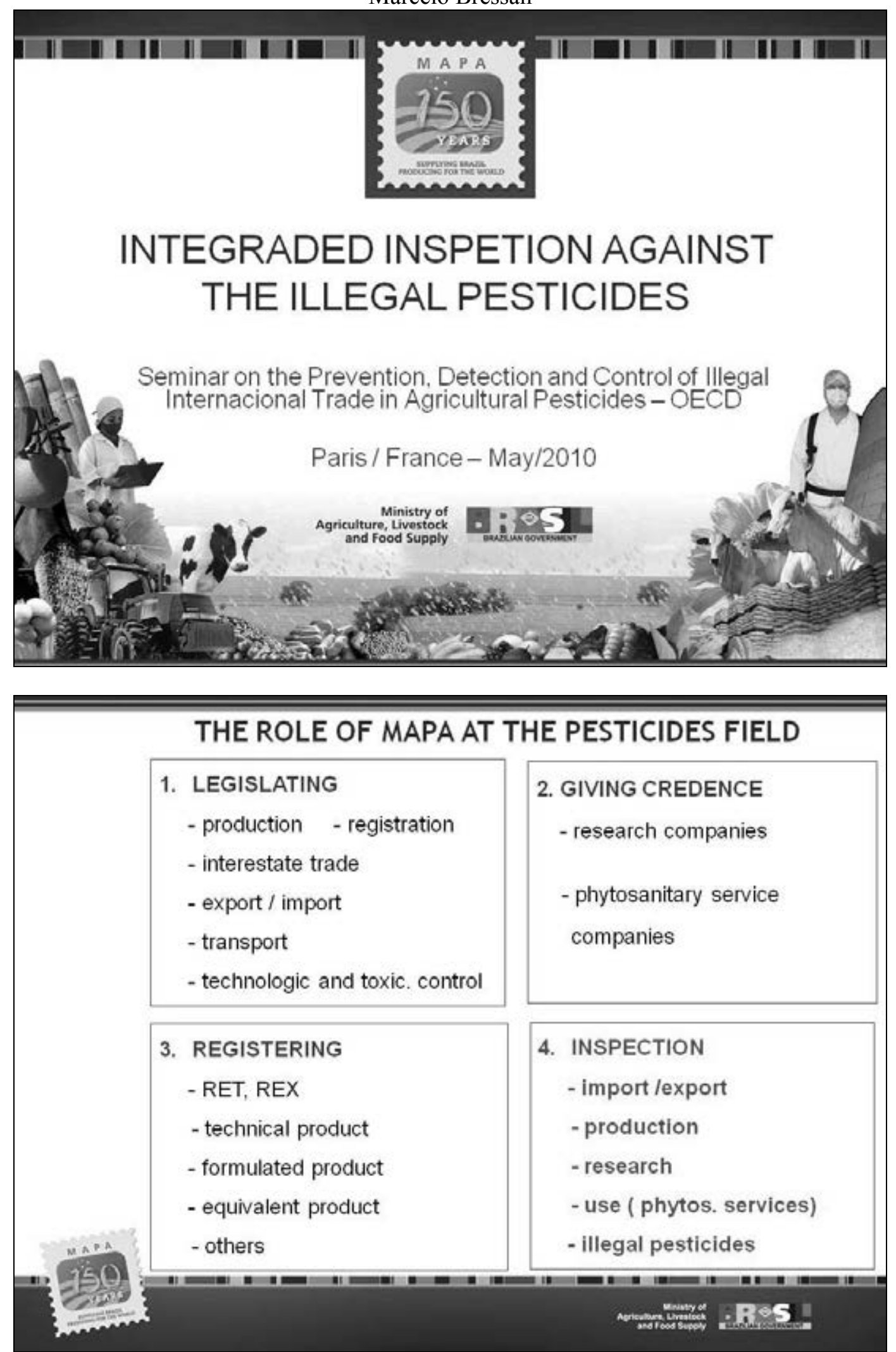

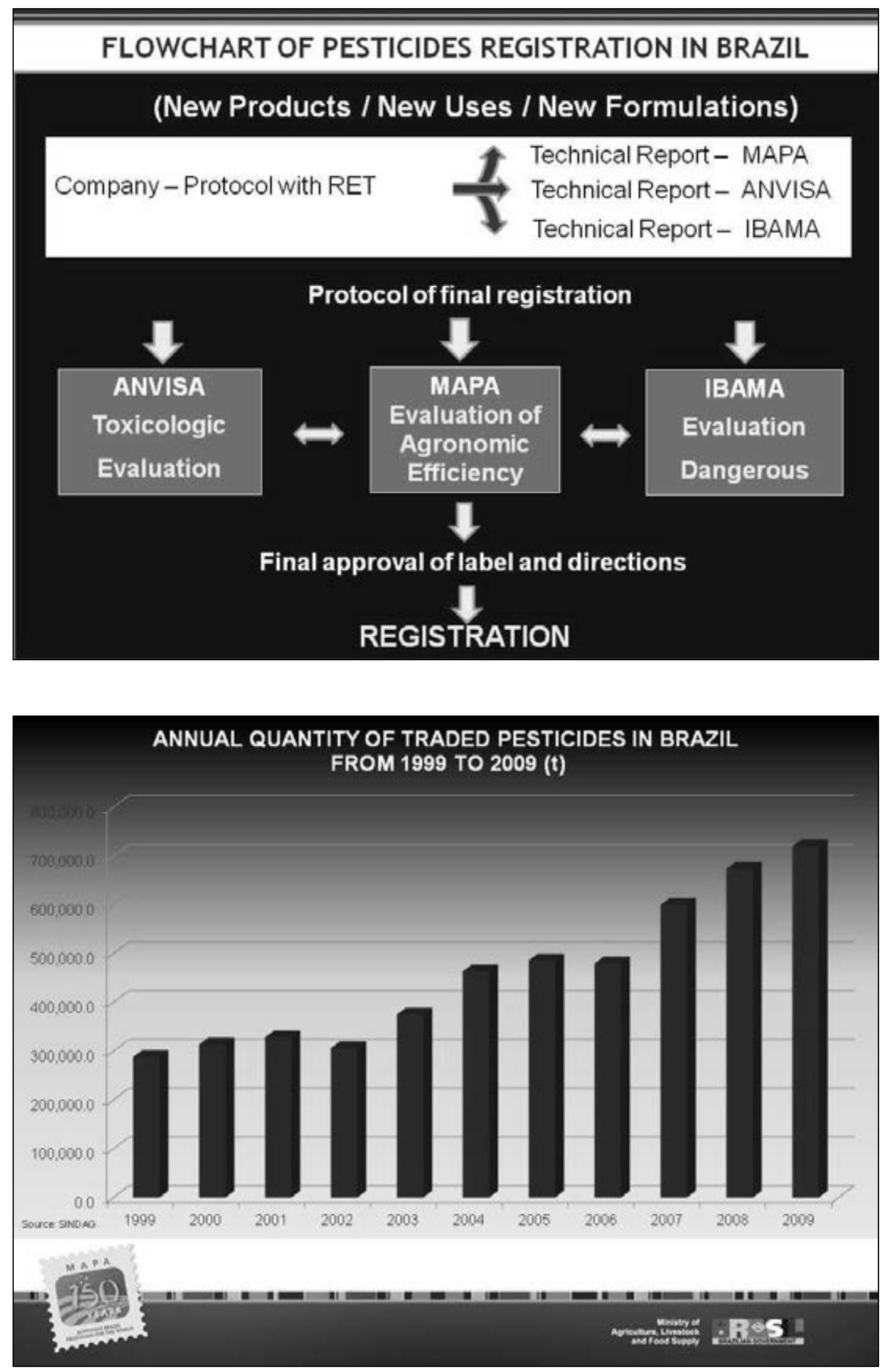

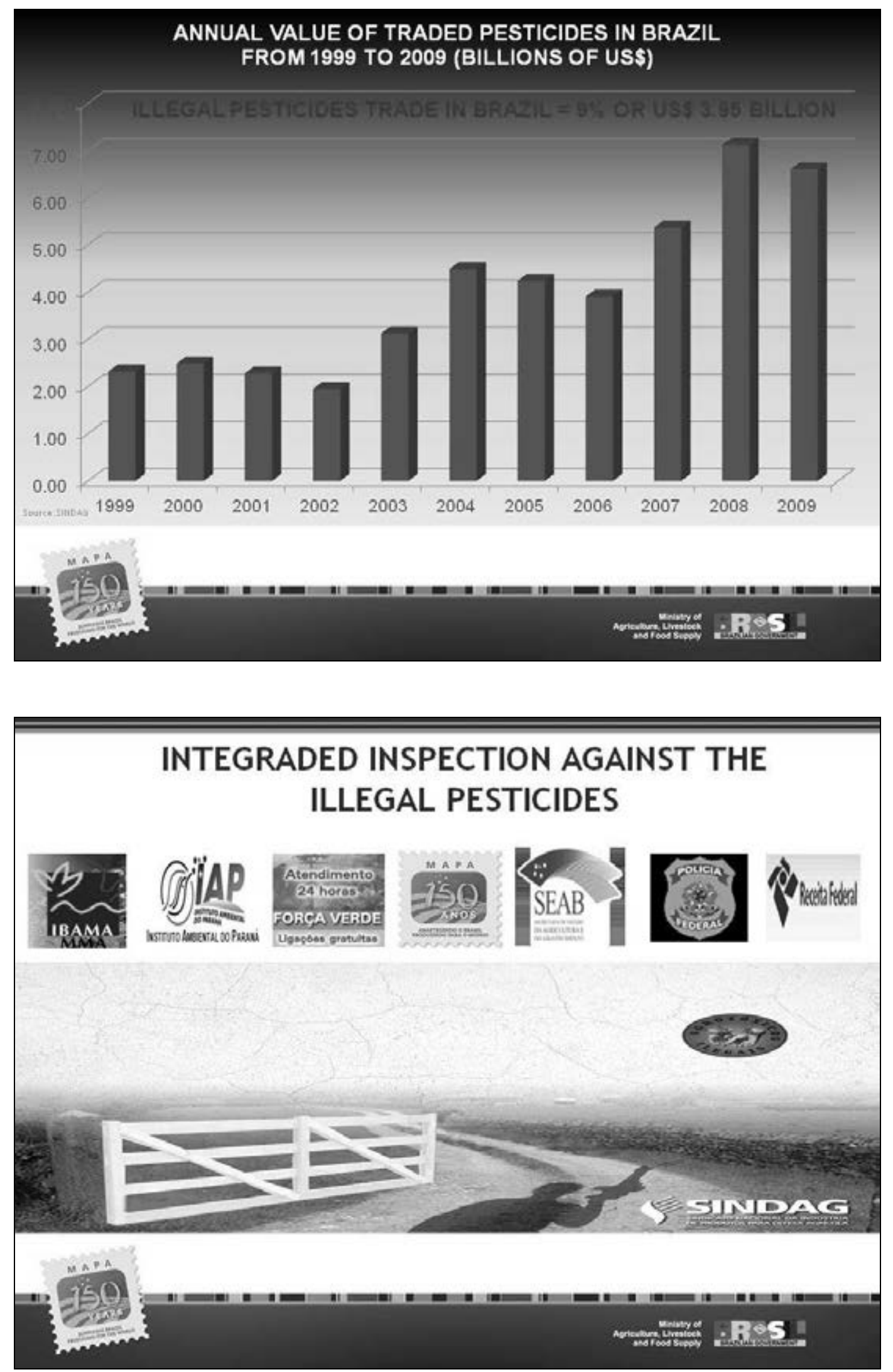

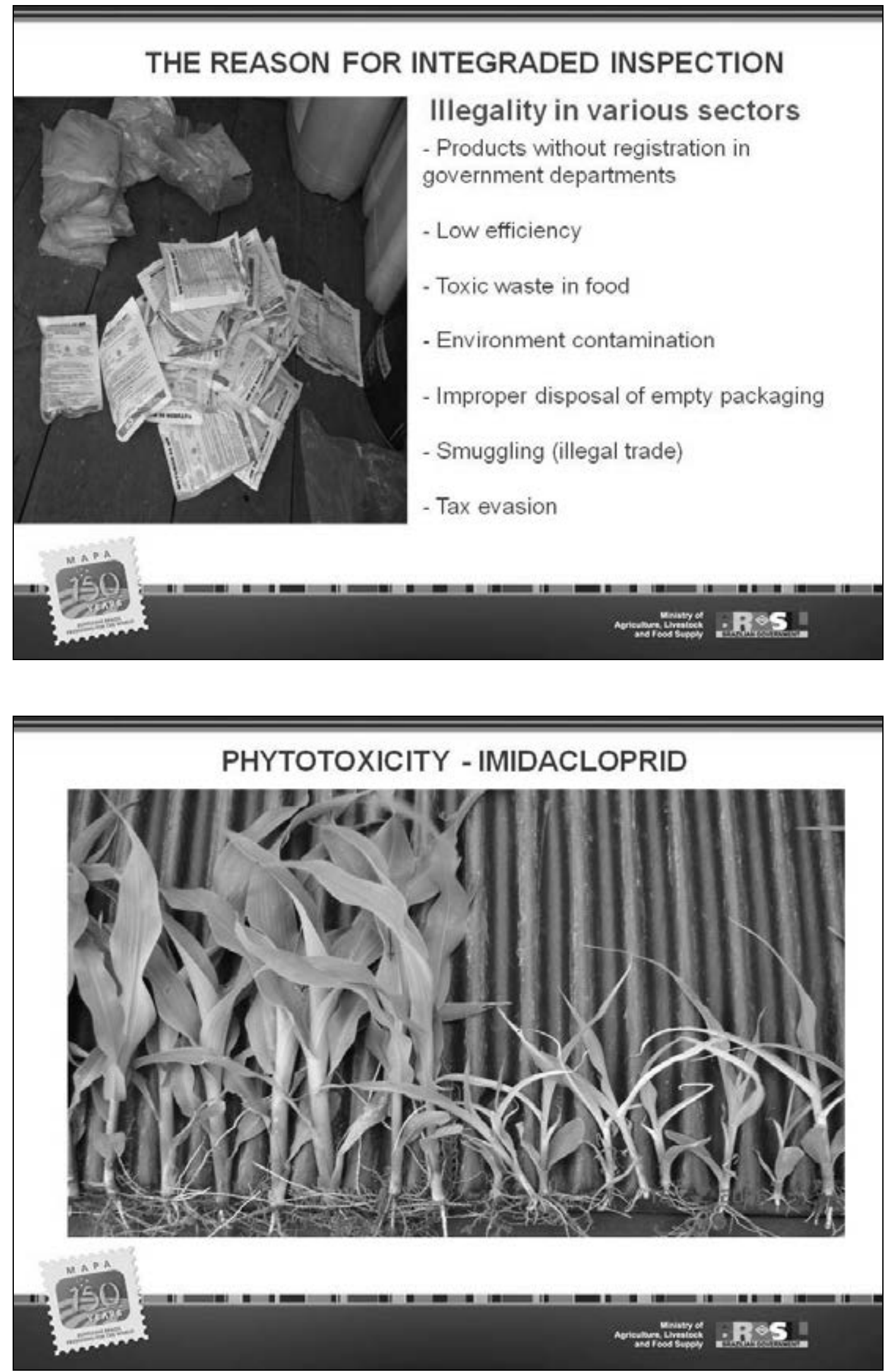
ENV/JM/MONO(2011)6
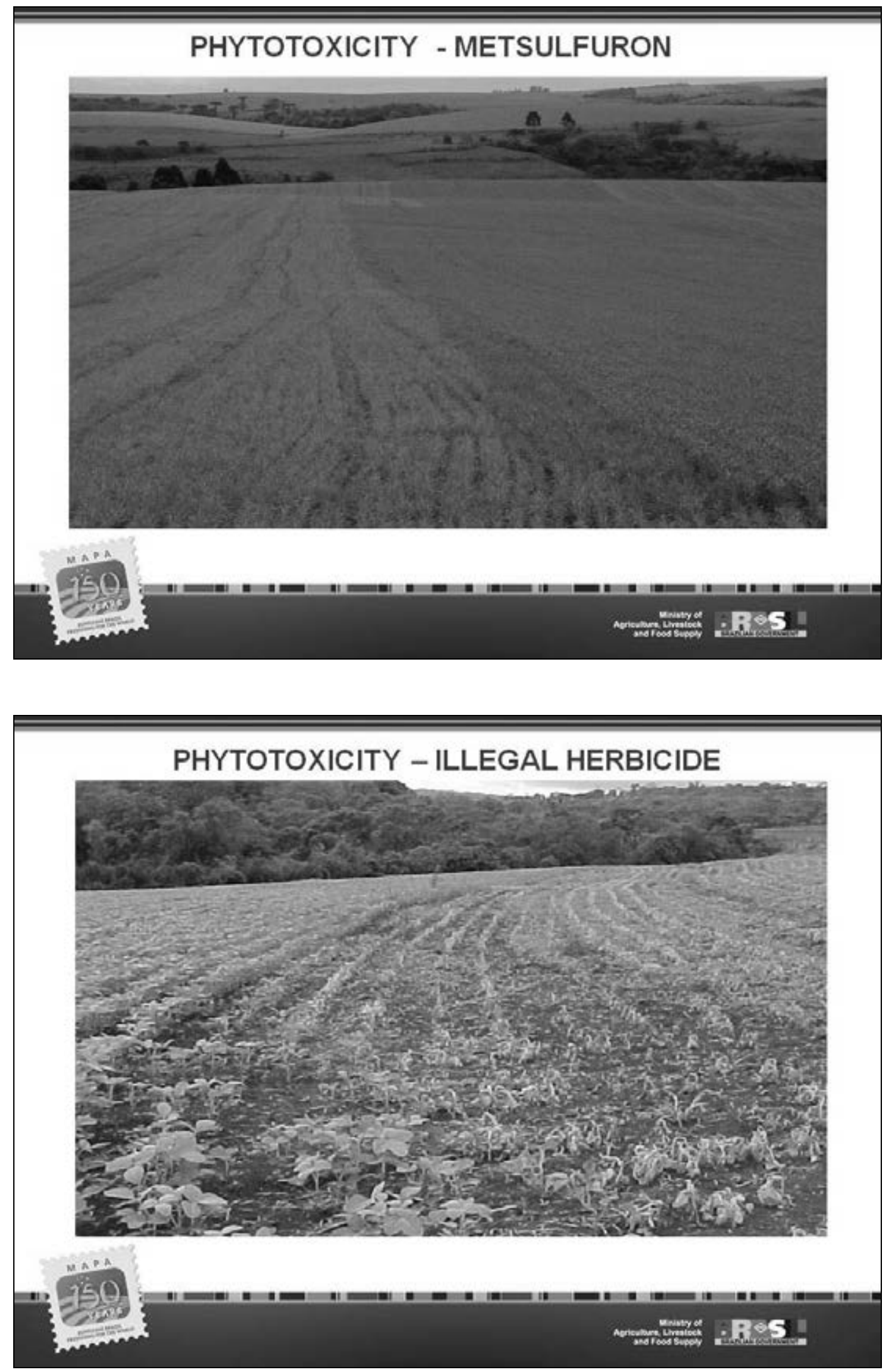

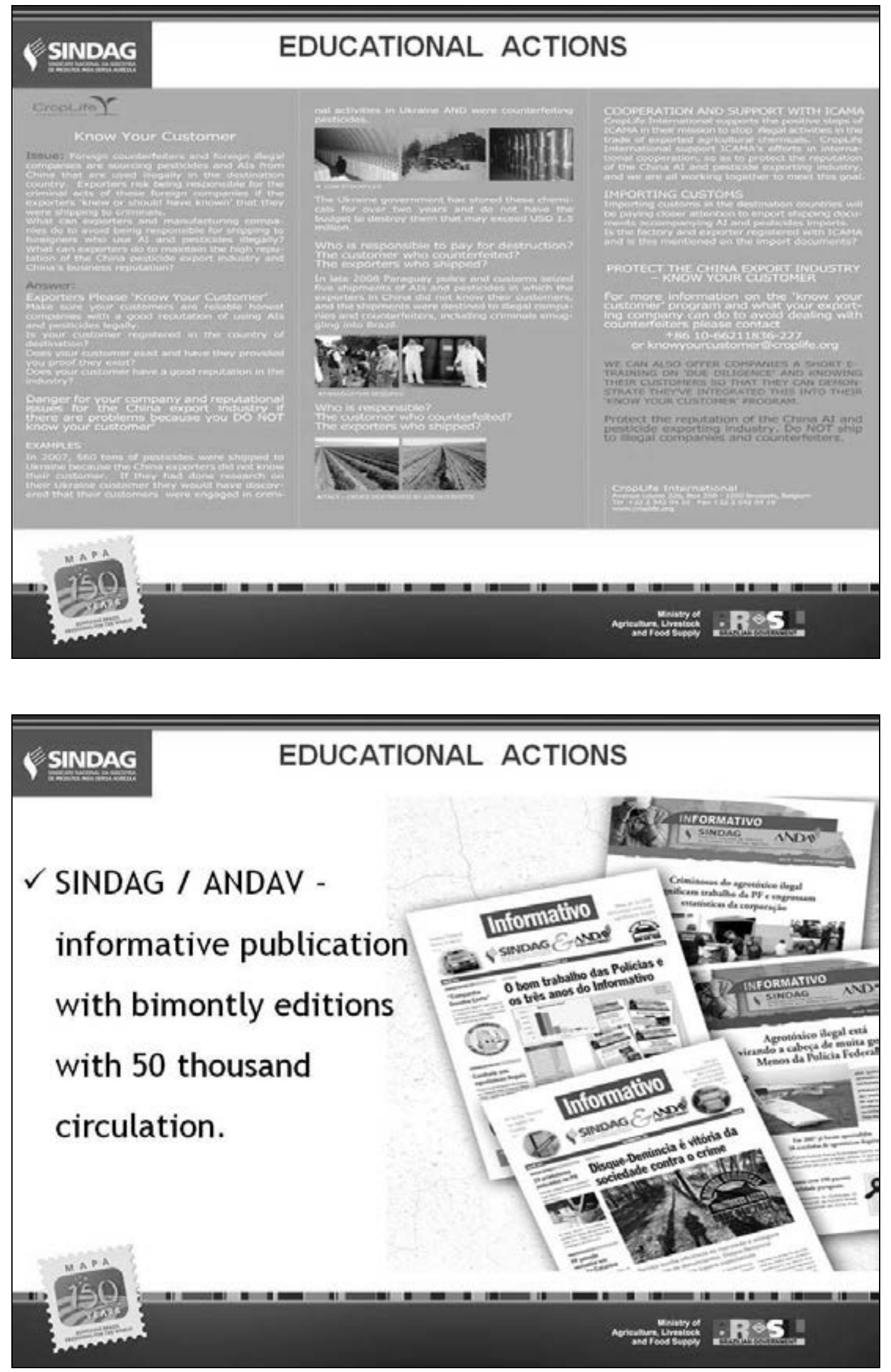

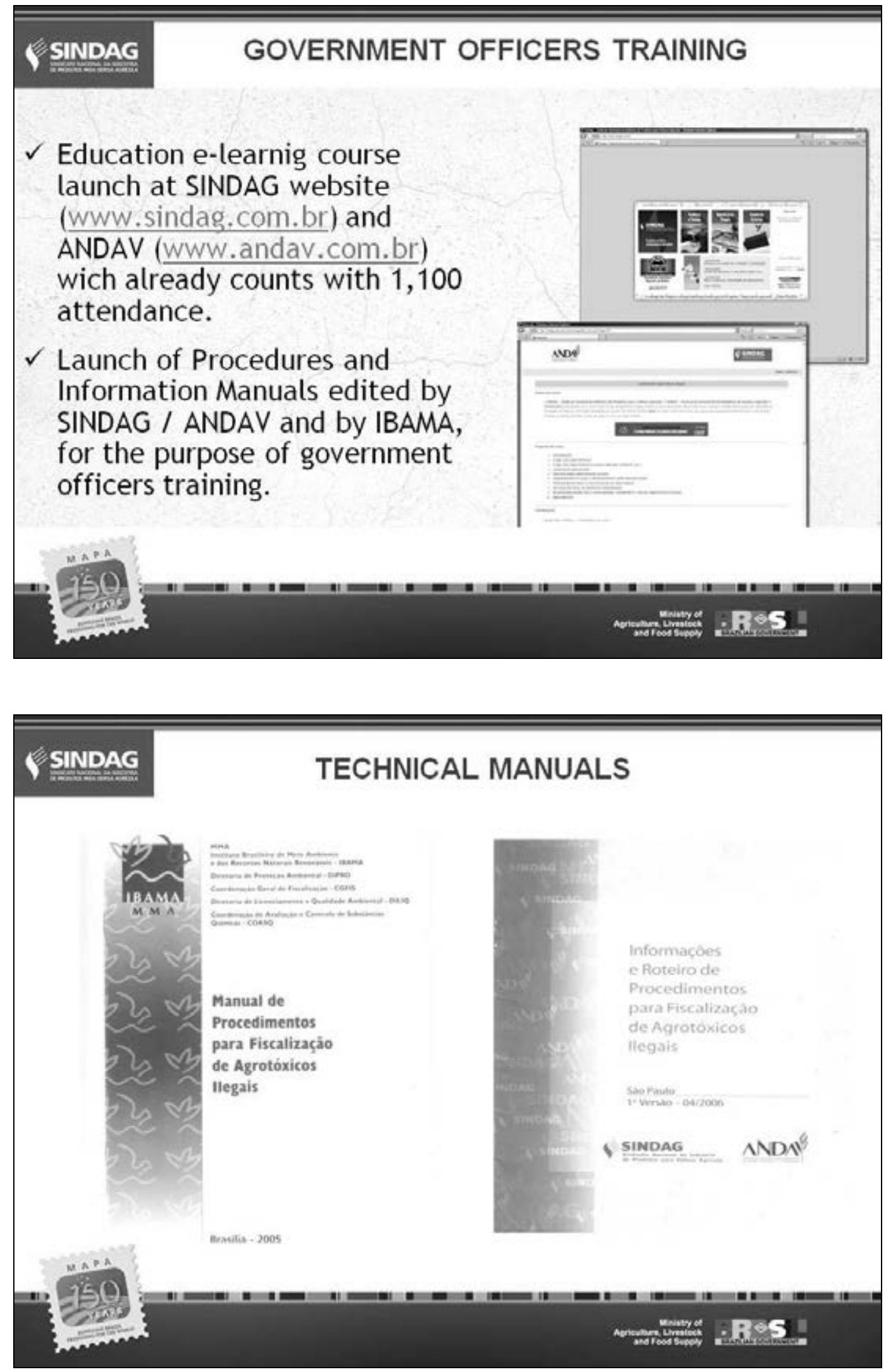

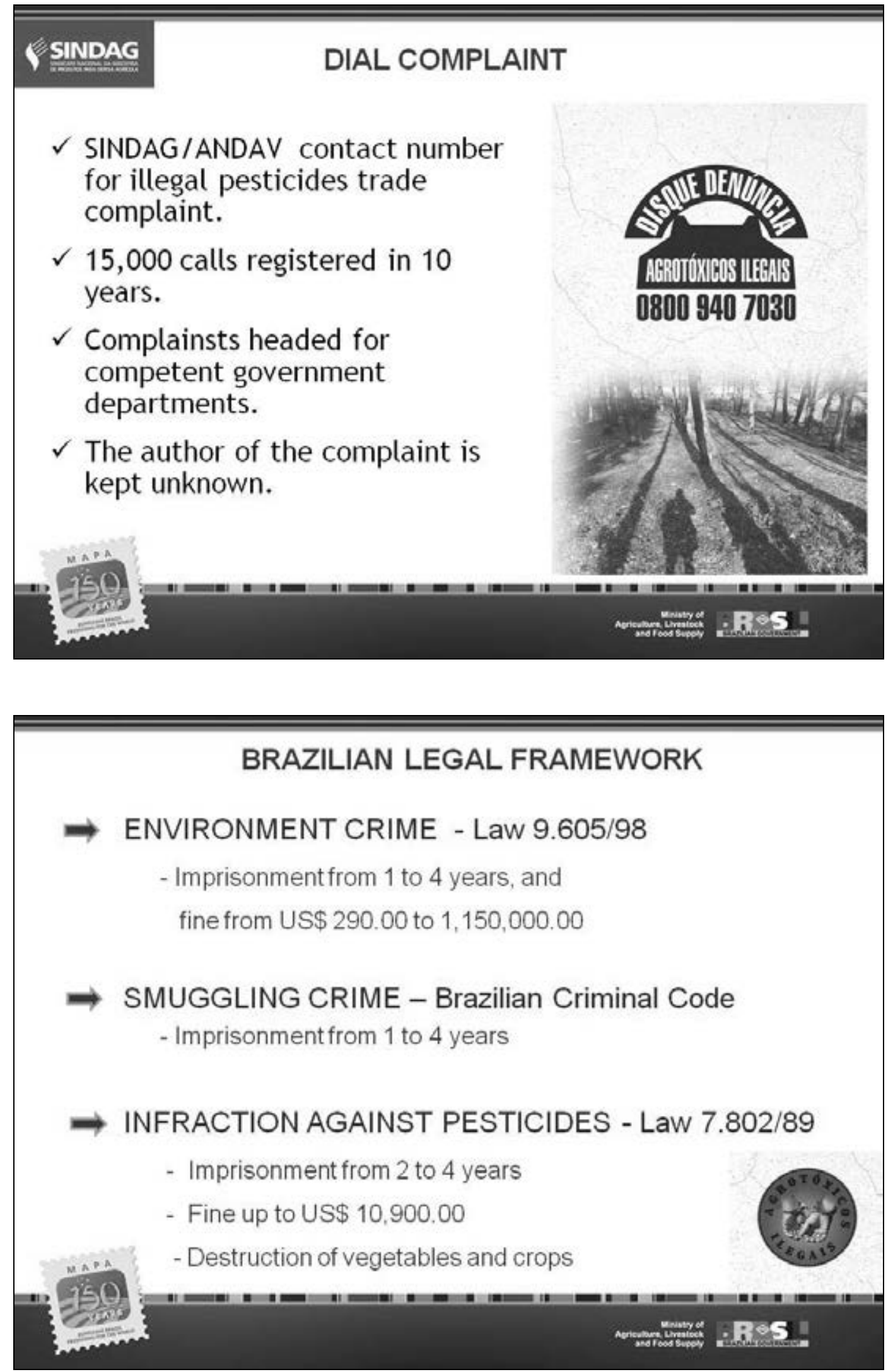

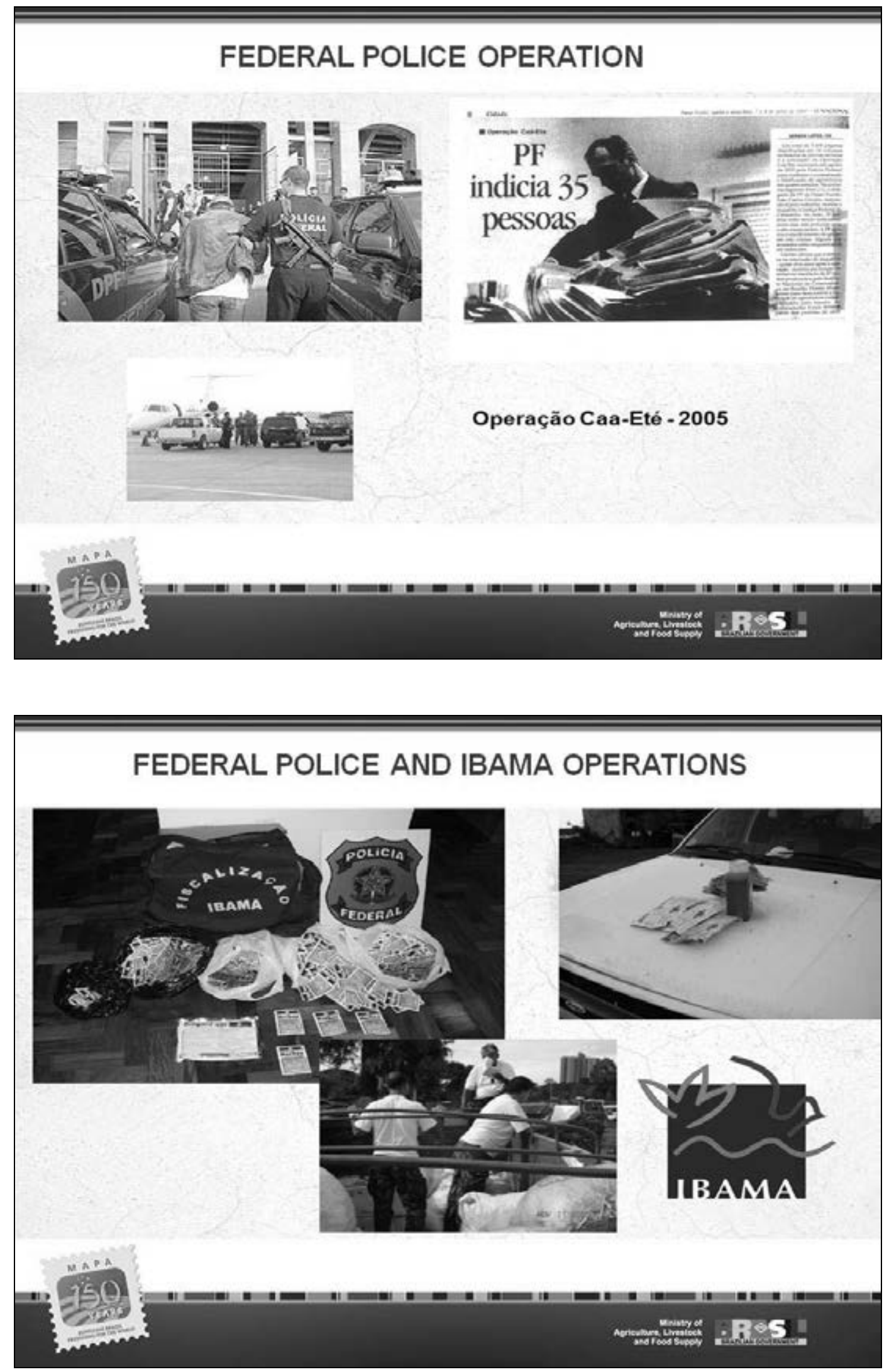

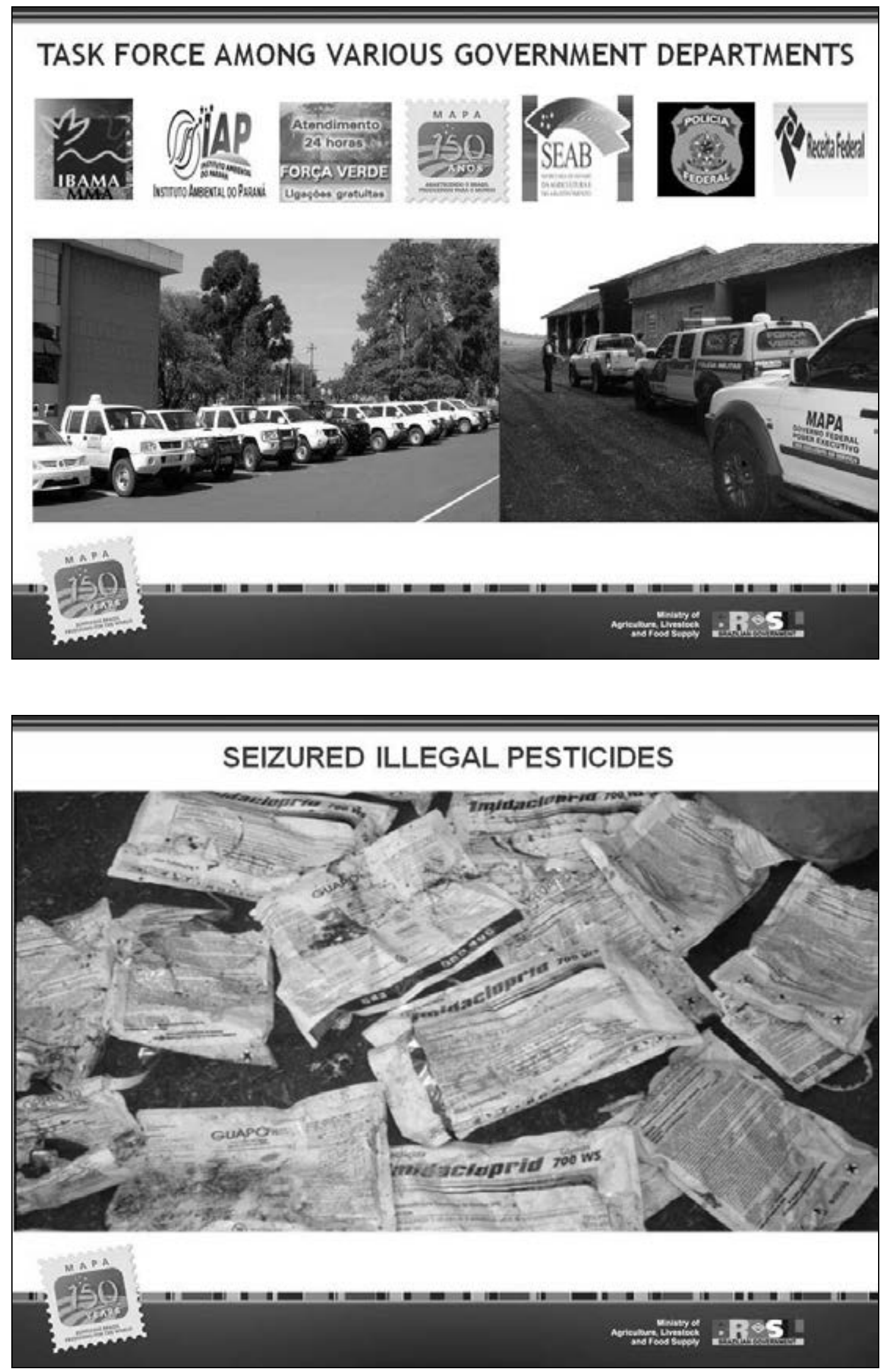

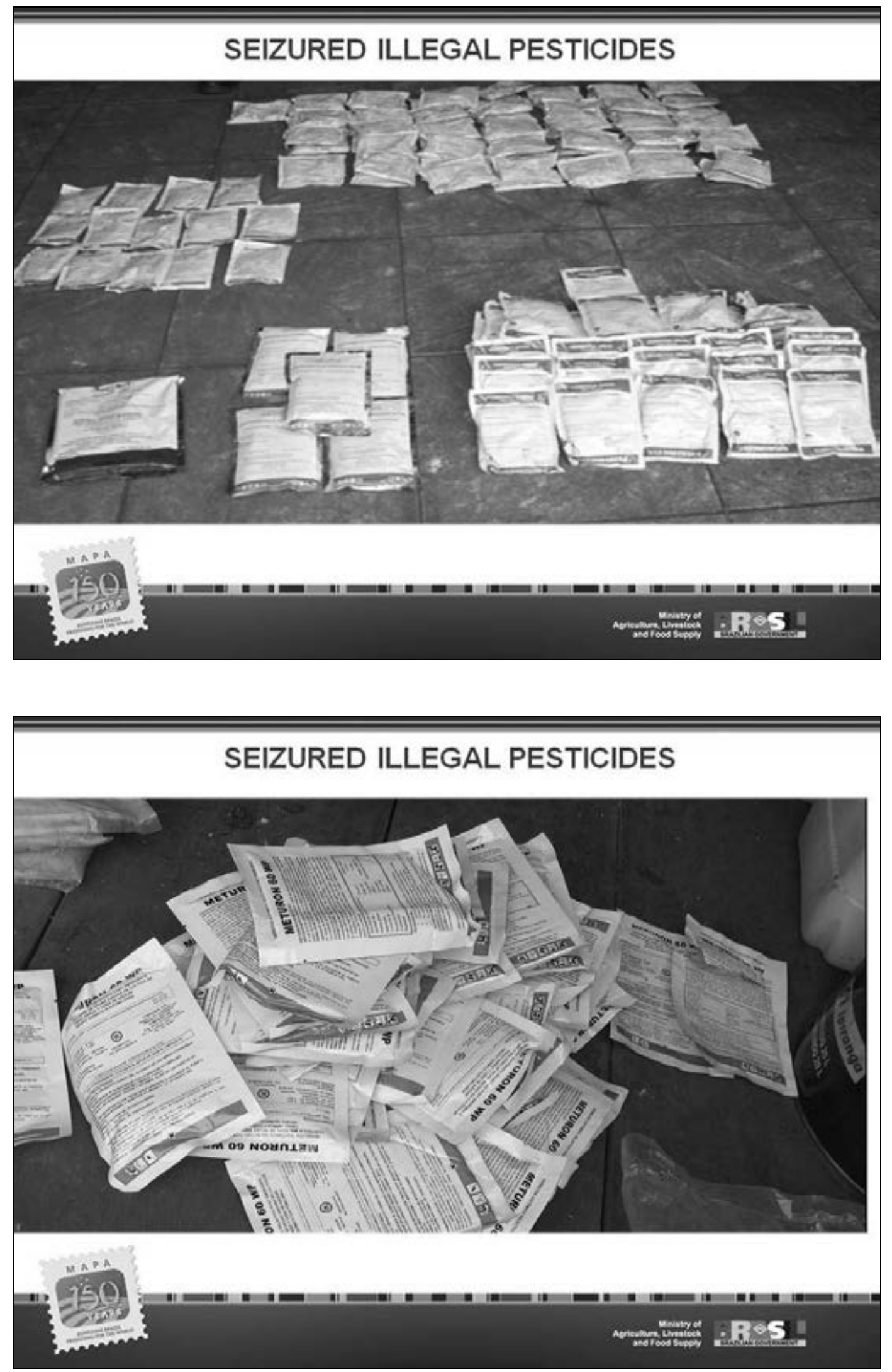

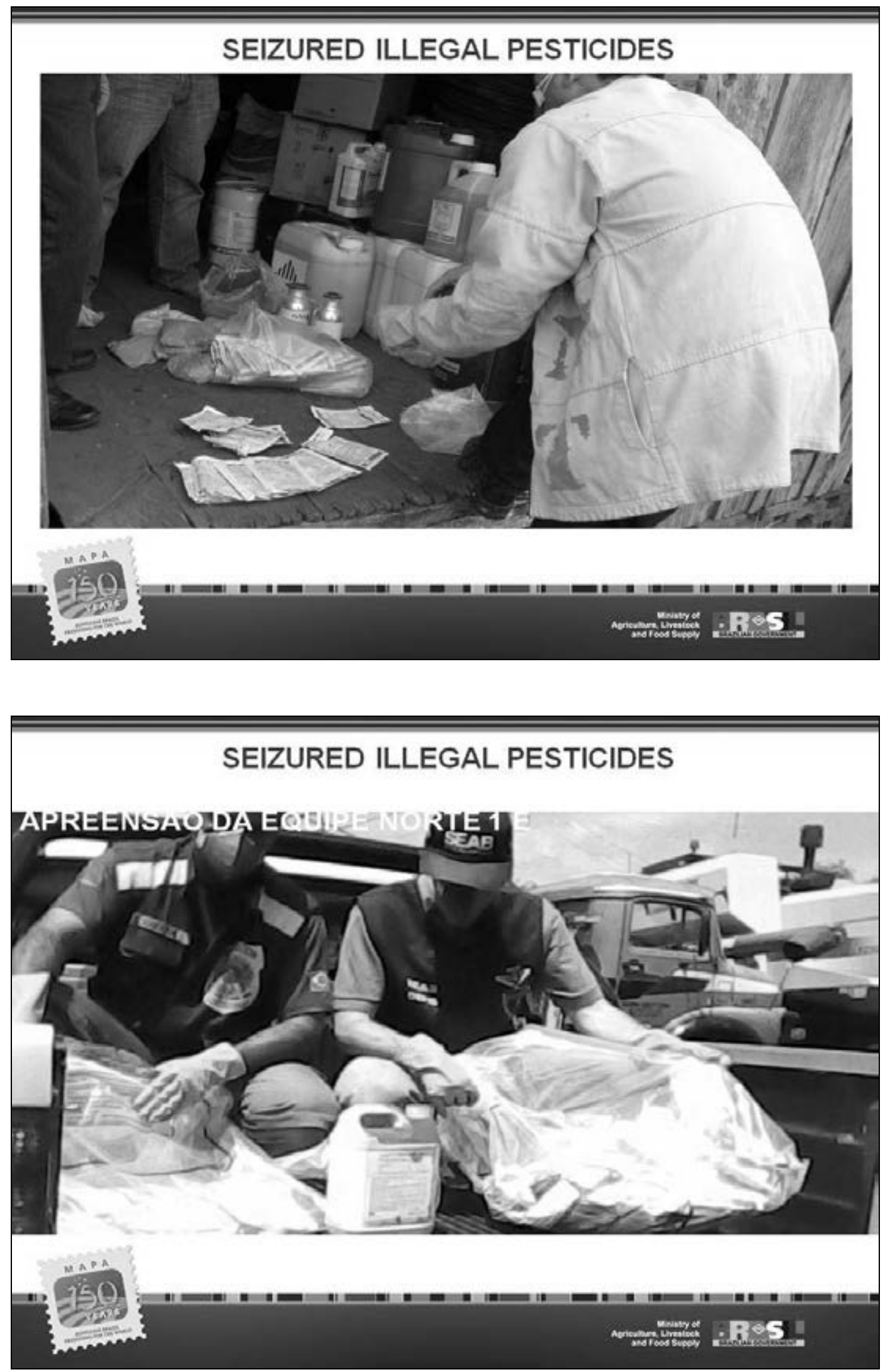

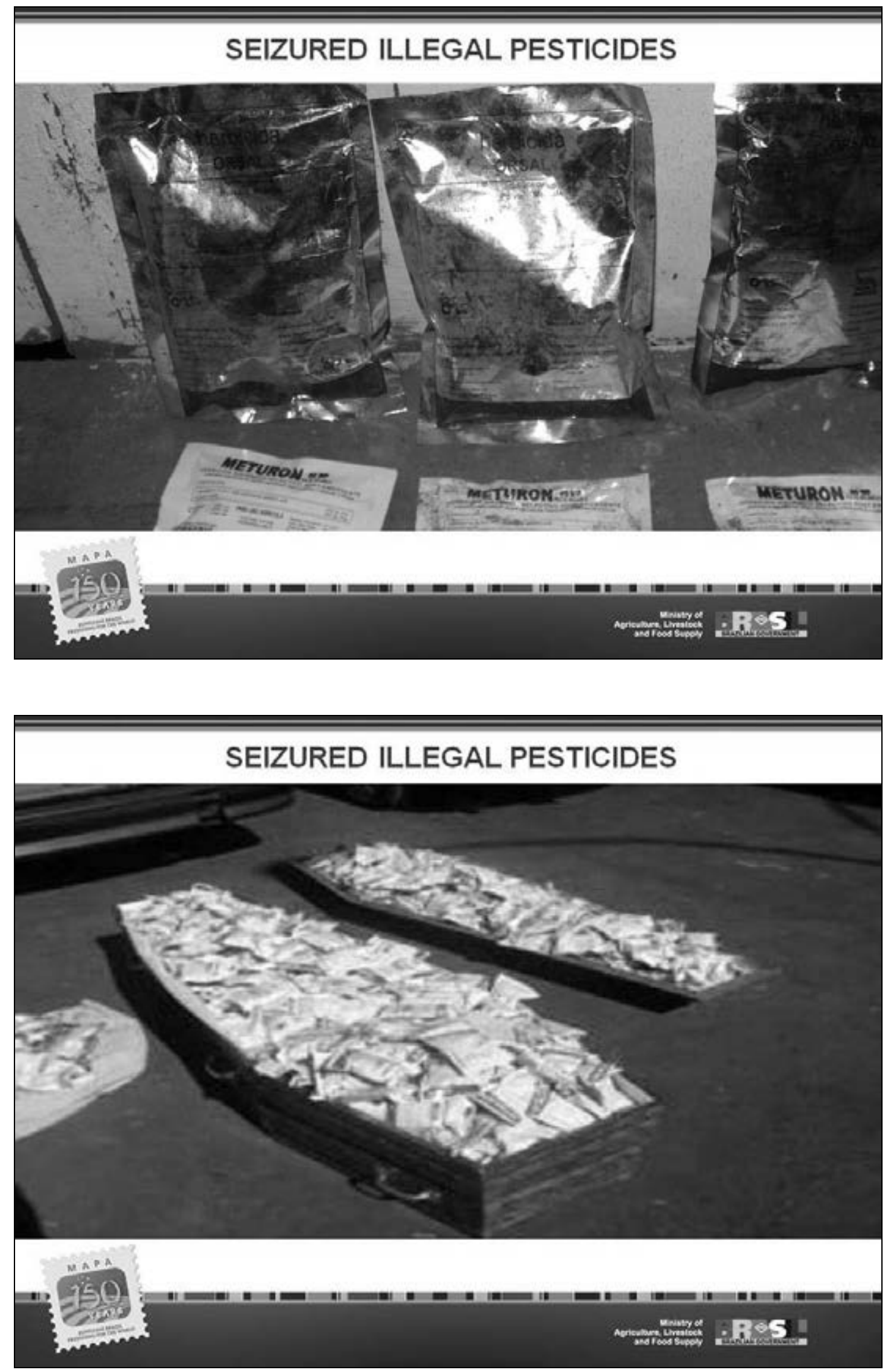

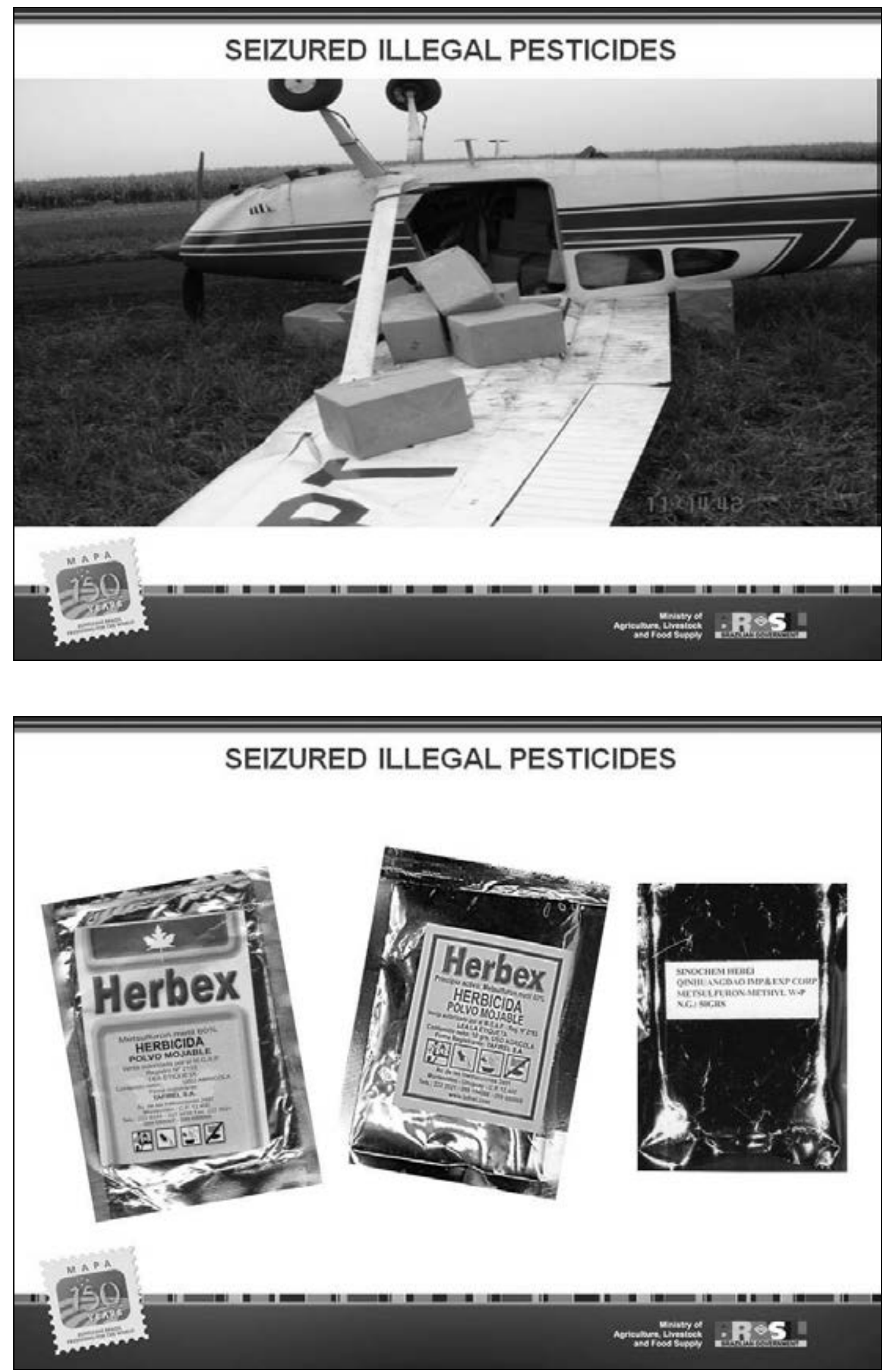

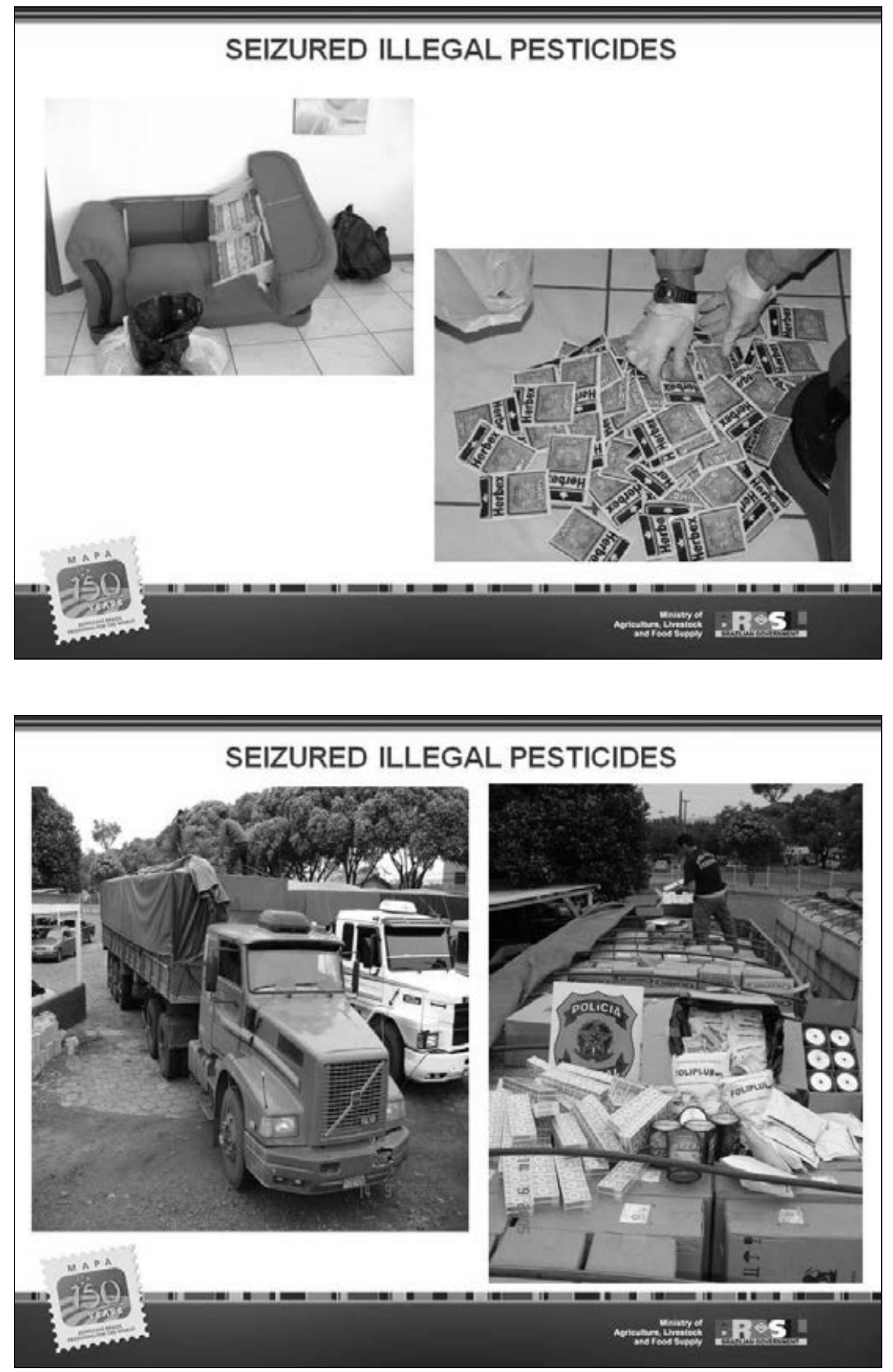
THE RESULT OF OPERATIONS FROM 2000 TO APR/2010

$\checkmark$ MAIN ACTIVE INGREDIENTS SEIZURED CLORIMURON; METSULFURON; IMIDACLOPRID; TEBUCONAZOLE; FIPRONIL; GLIFOSATO; CARBENDAZIN; CLETODIN; DIFLUBENZURON; CLOMAZONE; BISPIRIBAC; PIRAZOSULFURON; QUINCLORAC; LAMBDACIALOTRINA; IMAZETAPIR.

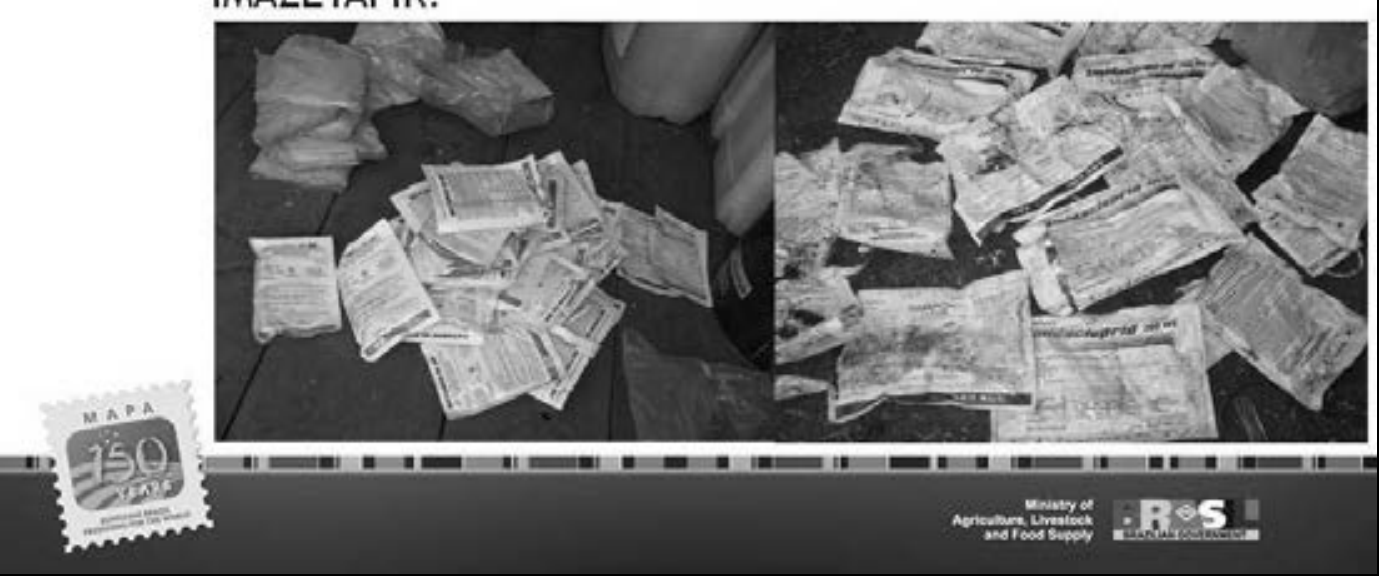

THE RESULTS OF OPERATIONS FROM 2000 TO APR/2010

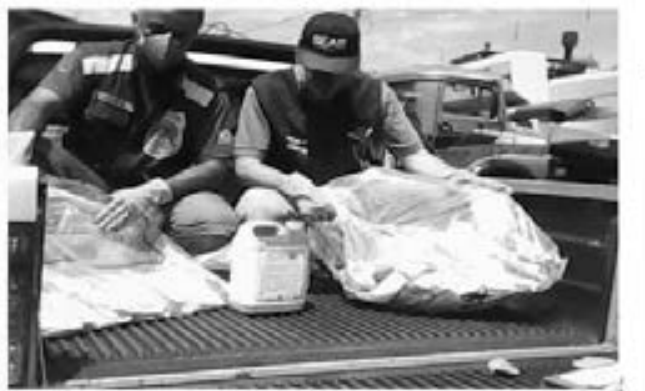
TASK FORCE

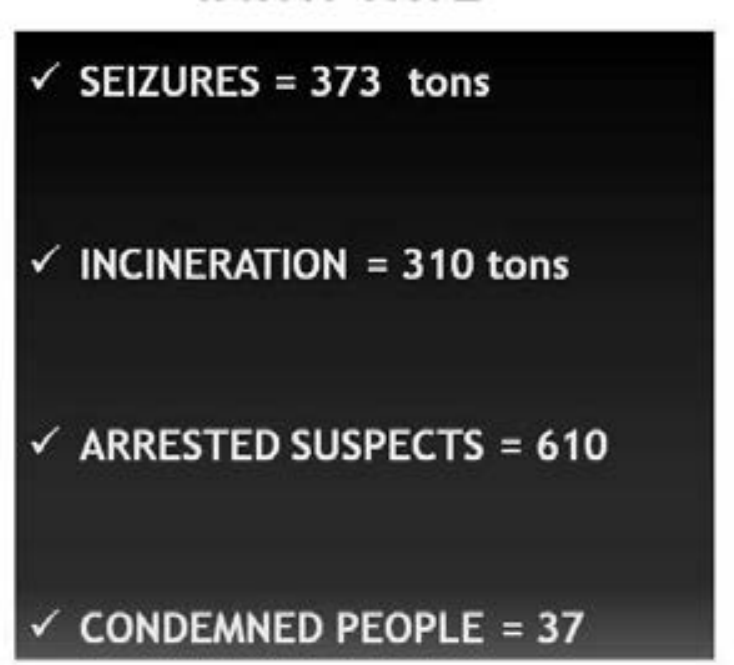




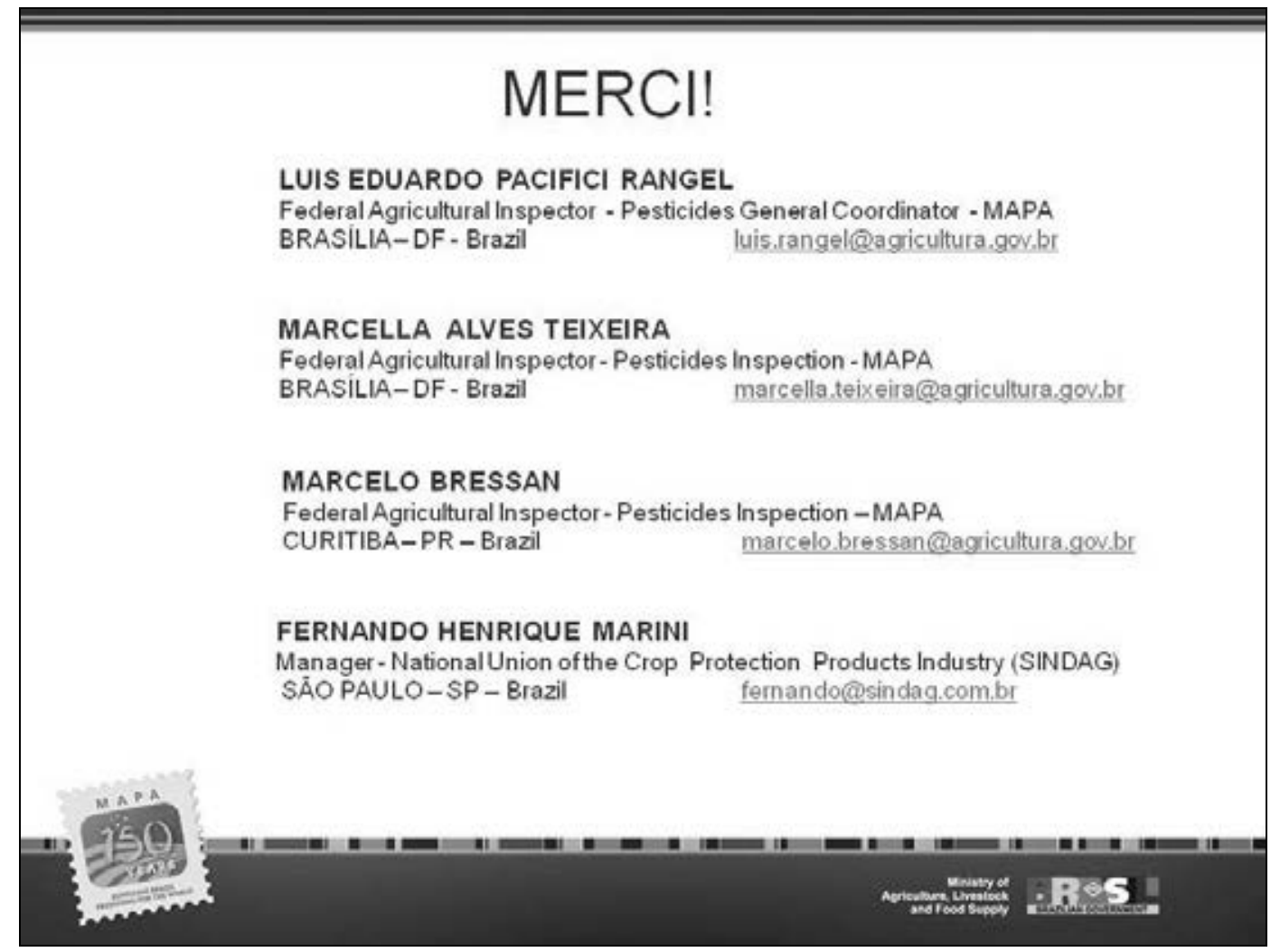




\section{Presentation 6}

France

Maurice Boureau

National Brigade for Veterinary and Phytosanitary Investigations

B.N.E.V.P.

Ministry for Food, Agriculture and Fisheries

FRANCE

\section{Investigations on counterfeit and illegal Plant Protection} Products in France and new thoughts about the Means of fighting

Serninar

Risk Reduction through Prevention, Detection and Control of the Illegal International Trade in A gricultural Pestiddes

PARIS, Wednesday 19 May 2010 $O R C D$

National Brigade for Veterinary and Phytosanitary Investigations (BNEVP-Manager: C. COLLINET) Ministry for Food, Agriculture and Fisheries

" Its task is to manage investigations with the aim of fighting against organized crime in veterinary and phytosanitary health field. It also provides technical support to the Directorate for food, the regional sanitary control services or the legal authorities » 


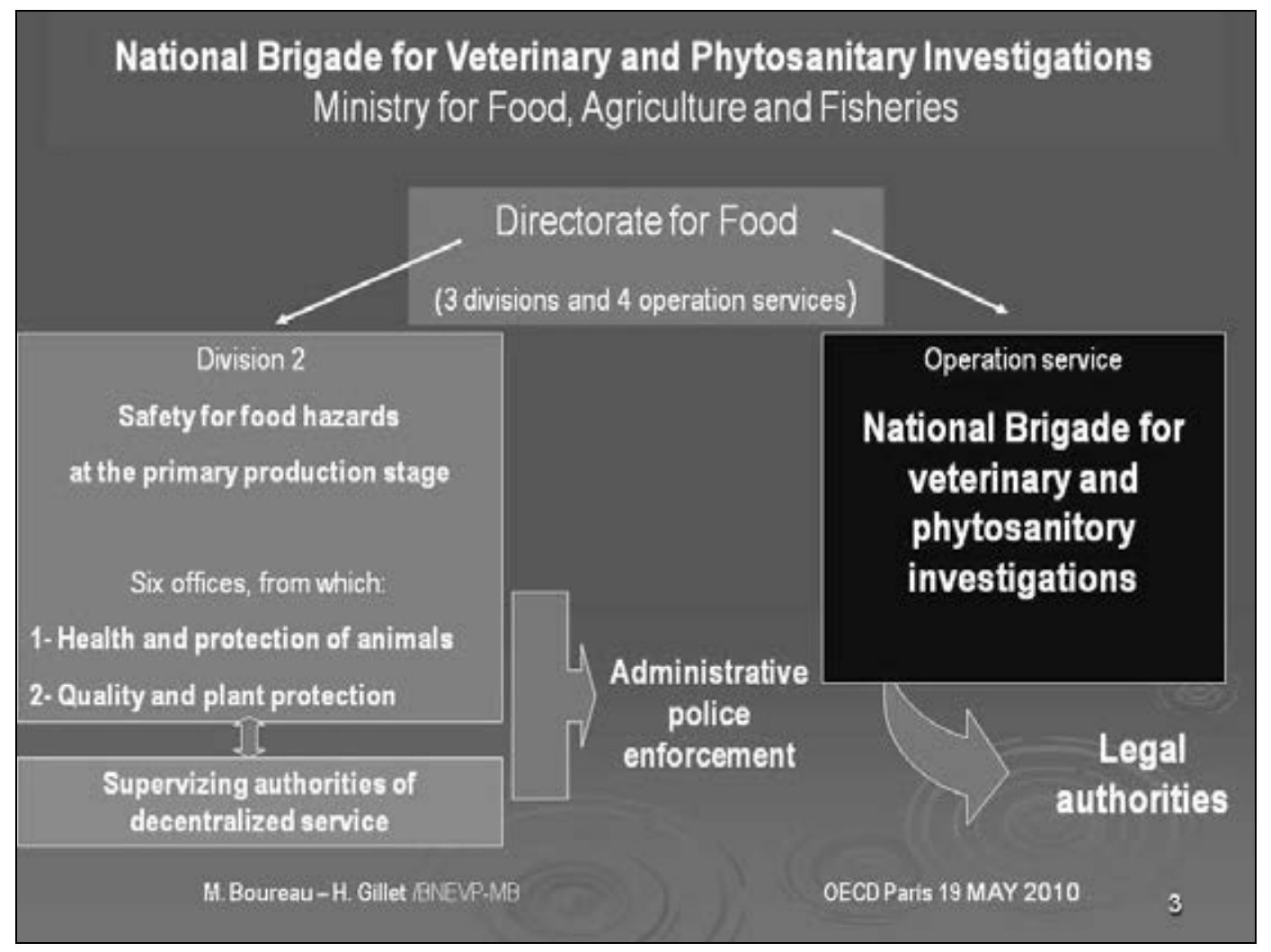

National Brigade for Veterinary and Phytosanitary Investigations Ministry for Food, Agriculture and Fisheries

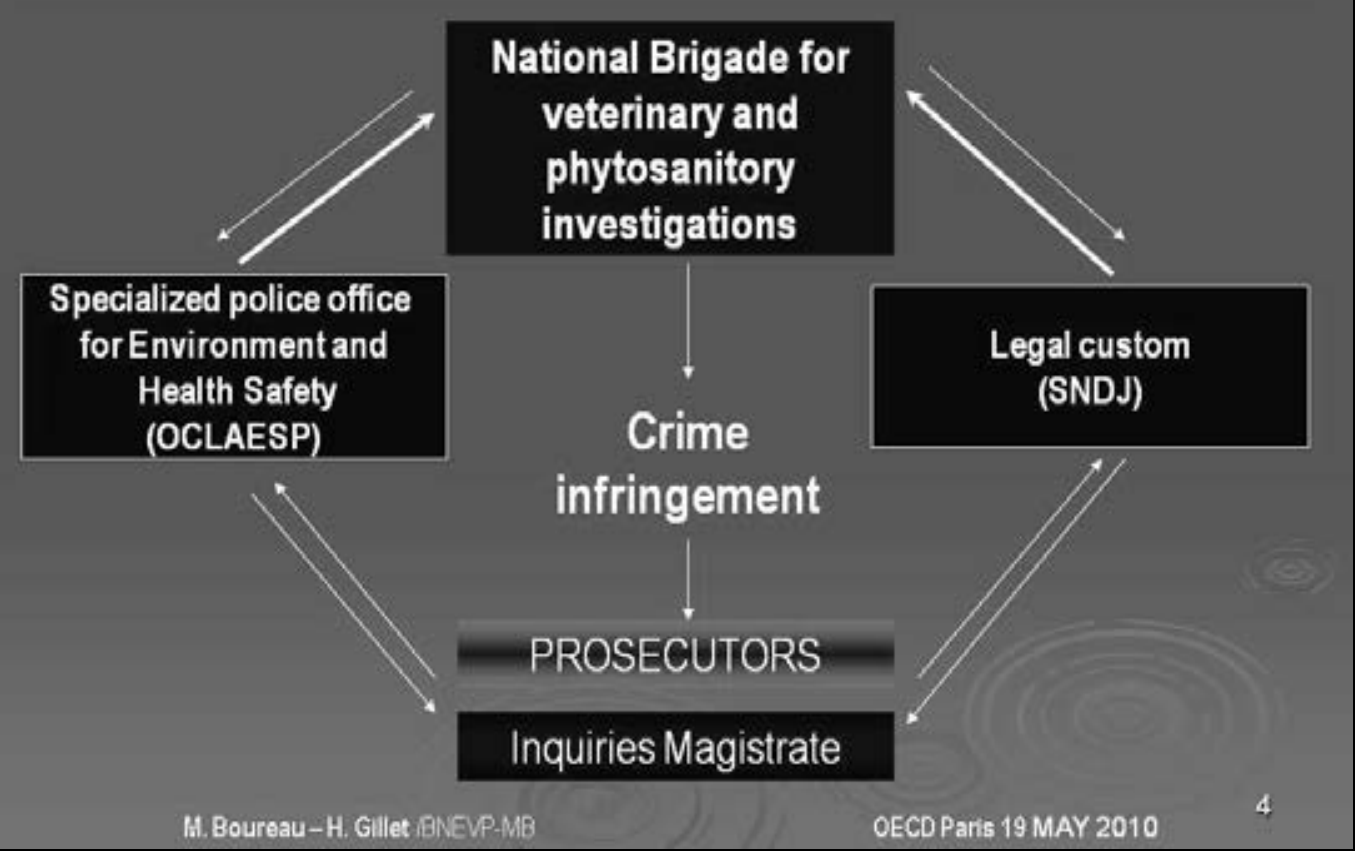


National Brigade for Veterinary and Phytosanitary Investigations Ministry for Food, Agriculture and Fisheries

$>$ Counterfeiting of registered trademark: product which has been deliberately and fraudulently labeled, thus misleading on its identity (or its producer).

$>$ counterfeiting of the active ingredient and formulation of the products

\section{ALL KIND OF PRODUCTS CAN BE AFFECTED}

\section{BrandedProducts}

\section{Generic products}

\section{Or parallel import products}

\section{IIlegal and counterfeit products are often marketed as parallel import products,}

which is a EU simplified procedure used by importers for placing their products on the market of the EU importing country where an authorization alreacly exists

MEANS OF FIGHTING AGAINST COUNTERFEIT PRODUCTS AND ILLEGAL TRADE Ministry for Food, Agriculture and Fisheries - DGAL/BNEVP

\section{Who are the approved holders of authorized imported}

\section{products in FRANCE?}

- Companies which market only imported products in several EU countries.

They are registered in Germany, Belgium, Austria, Luxembourg

and have organized networks out of the EU

-Some French distributors which sell only on the domestic area

\section{Who are the buyers?}

- Wholesalers who sell to exclusive networks of distributors -Some individual distributors in direct business

\section{Who sales to final users?}

\section{-All distributors which want to increase profit margin}


MEANS OF FIGHTING AGAINST COUNTERFEIT PRODUCTS AND ILLEGAL TRADE Ministry for Food, Agriculture and Fisheries - DGALIBNEVP

\section{Investigations carried out by BNEVP in the domain of trade} of plant protection products (PPPs) for three years

\section{CONTROLS AGAINST DISTRIBUTORS}

\section{TONS}

\section{OF ILLEGAL PRODUCTS}

\section{WITHDRAWN FROM THE MARKET}

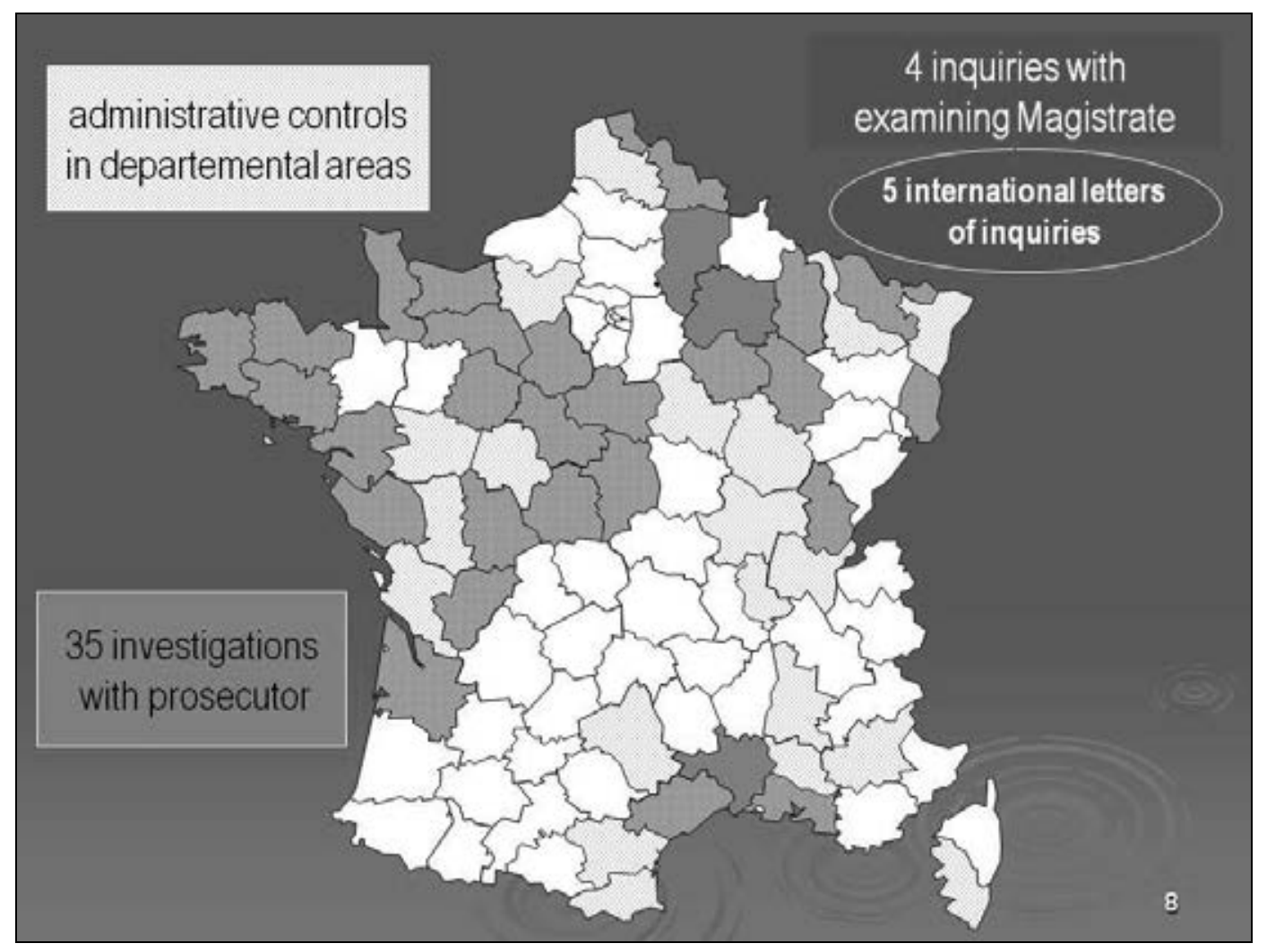




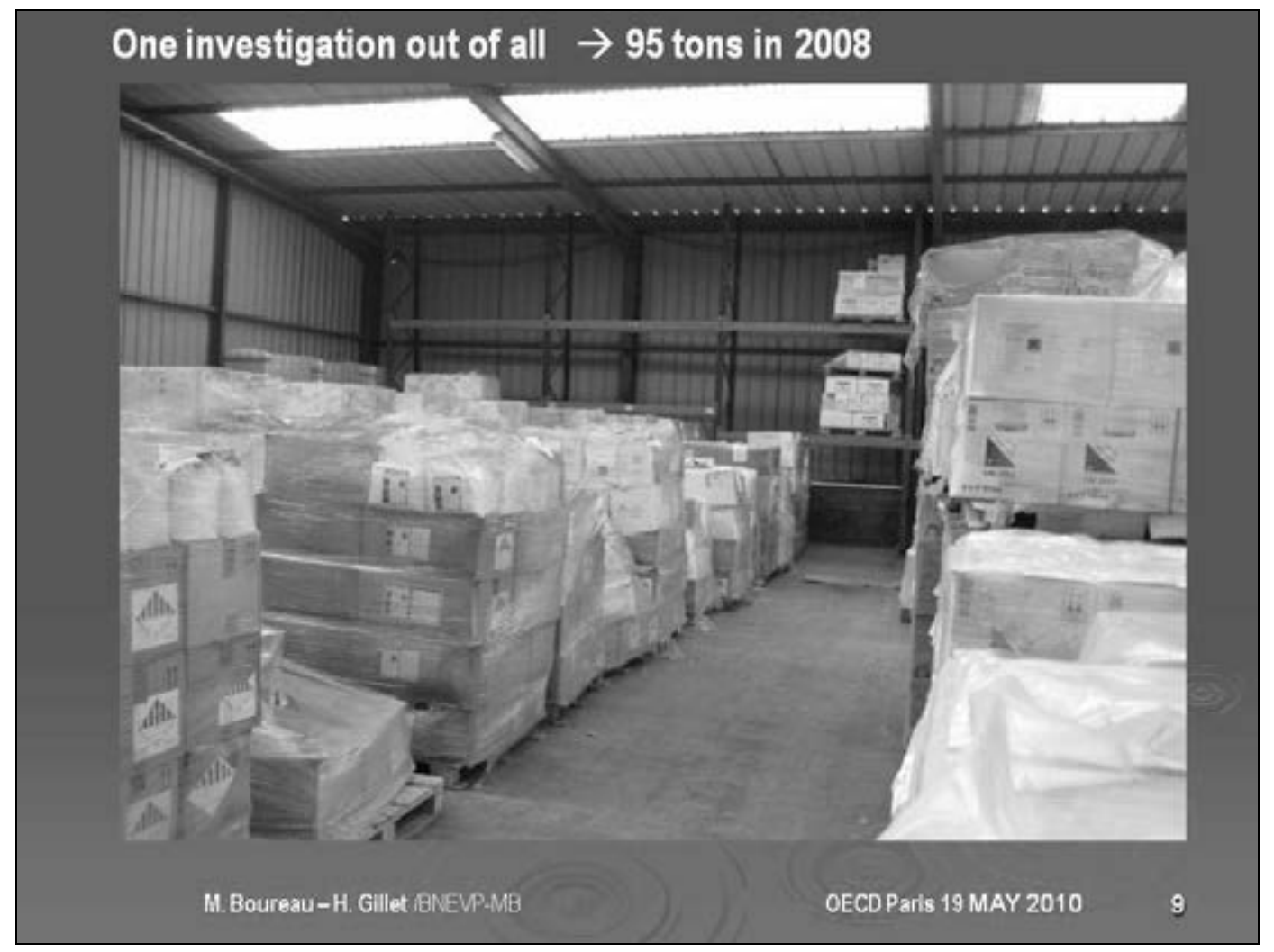

In 2009, 120 thousand liters of counterfeit glyfosate based product were seized; Legal and custom based investigations are being

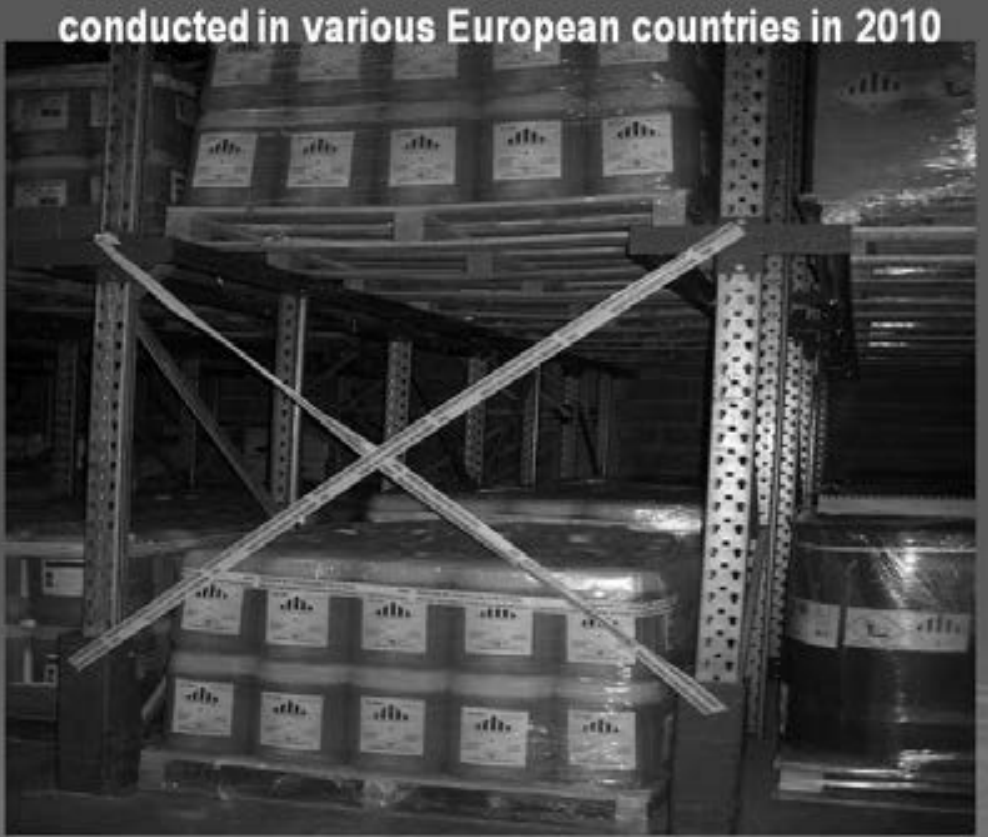




\section{Detected illegal parallel import products $\rightarrow$ the results of the investigations}

Packaging and labelling

- Re-packaging of pesticides which did not go through health safety administrative control

- Counterfeit of the trademarklabel

- Indications of the name of the origin manufacturer on the parallel import PPPs single label even thought the productis fake.

Chemical content

- Insecticide instead of fungicide

- Unidentified substances or lack of active substance

- Impurities and by-products or solvent above standard

- Composition similar to original product (minor difference in impuritylevels) $=$ high quality counterfeits

\section{INSECTICIDE INSTEAD FUNGICIDE}

\section{Reference product} =ROVRAL

$$
\text { A.S. }=53 \% \text { iprodione }
$$

Identify impurities $=0.005$

unidentify impurities $=$ retention time $9,27 \mathrm{~min}$

\section{Illegal product: \\ (fungicide)}

A.S. iprodione $=0 \%$

(insecticide)

A.S. pyrimicarbe $=45 \%$ 


\section{SOLVENT ABOVE STANDARD}

\author{
Référence Product:

$$
\text { A.S. }=104 \mathrm{~g} / \mathrm{l}
$$ \\ Naphtalène : $0,154 \%$ \\ Polyéthylène glycol \\ d'alkylphenol : $2,98 \%$ \\ Stickiness : +++

\section{Moisture content: ++}

Illegal Herbicide:

$$
\text { A.S. }=104 \mathrm{~g} / \mathrm{l}
$$

Naphtalène : $4,77 \%$

Polyéthylène glycol

d'alkylphenol : 0,78\%

\section{Stickiness :+}

Moisture content: +

\section{CONSEQUENCES}

\section{Health hazards}

Référence Product :

$X_{n} R 36 R 48 / 22$
Illegal Product:

$\mathrm{Xn}$ cat $3 \mathrm{R} 40$

Safety precautions for the user are under-evaluated and do not appear on the label

\begin{tabular}{|ccc} 
& \multicolumn{2}{c}{ Environmental hazards } \\
\hline Naphtalène & $>1 \%$ & Classement $\mathrm{N}$
\end{tabular}

\section{For treatments implementation}

Variation in terms of viscosity and humidity can affect the product's quality and performance 


\section{Example of repackaging of IP products with a fake pesticide}

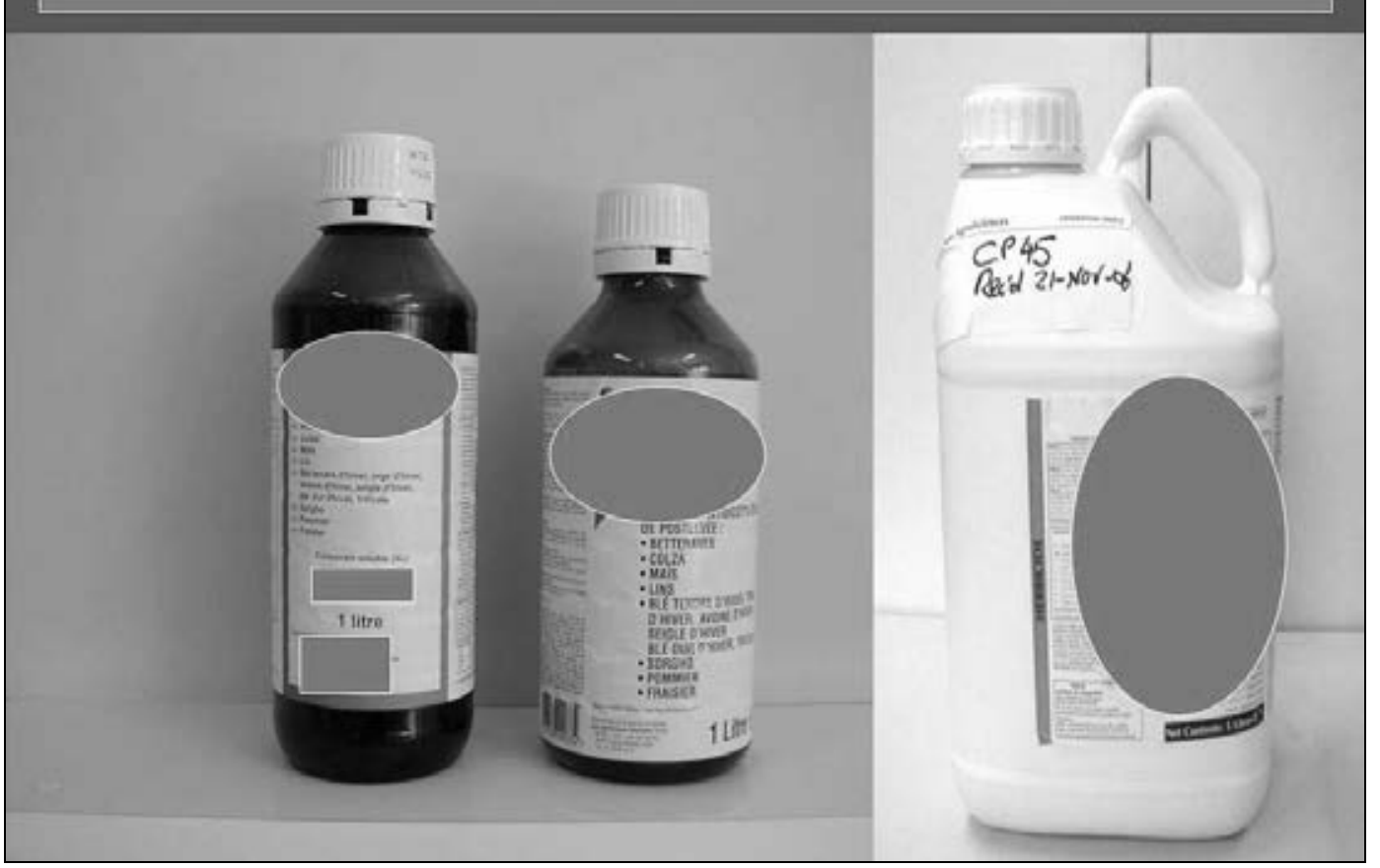

\section{Example of a glyfosate based product}

This import parallel product is authorised to import a product from the north of EU. Drums which we found on the market are sometimes single labelled but often double labelled: label of original manufactured product and label of the import parallel product (trade name)

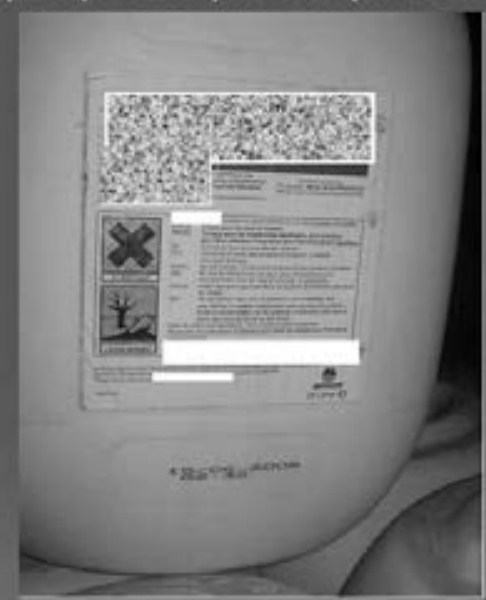

Single label of import parallel product

M Boureau-H Gllet ISNEVP-MB

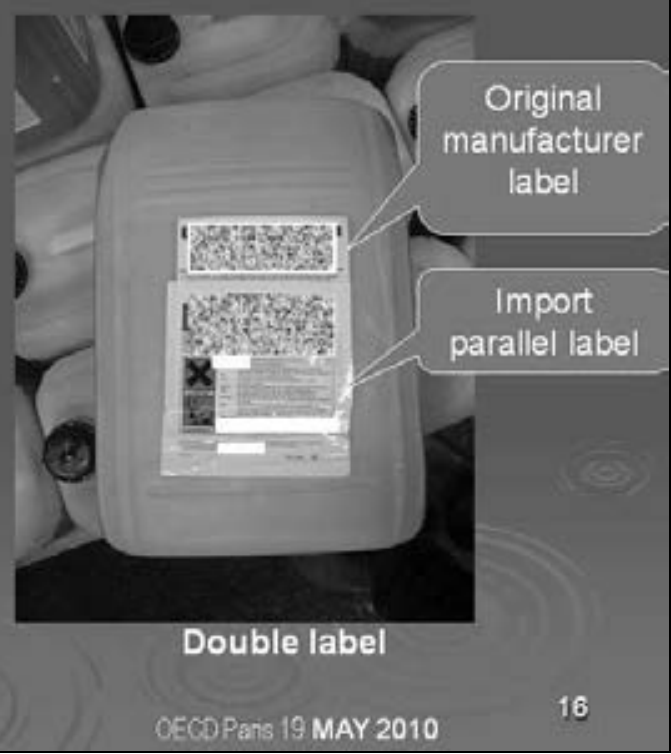



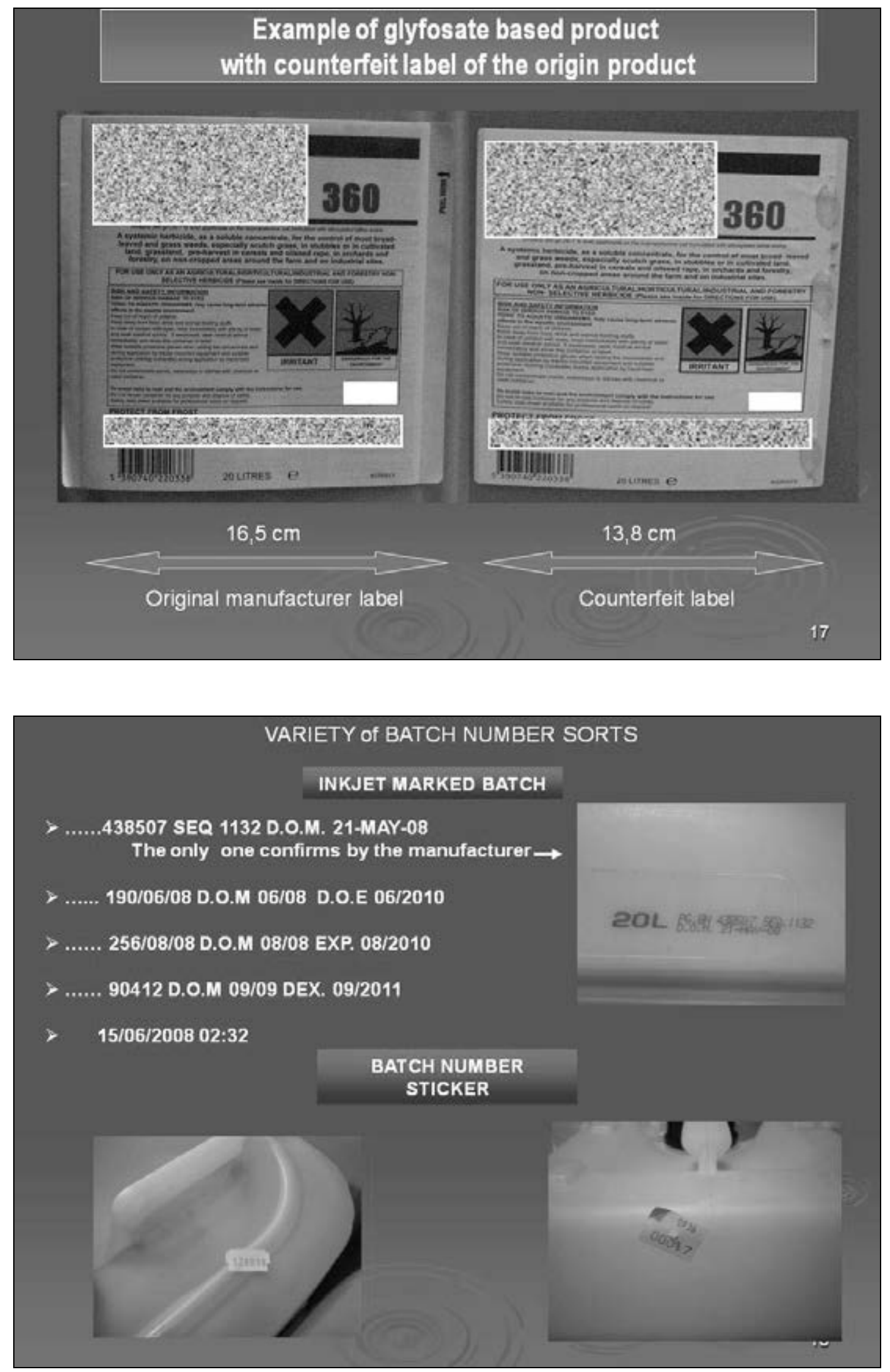


\section{Three additionnal infringements have been noticed during this inquiry:}

First, a common one: The parallel import product is authorized for importing products from several EU countries where they are registered. But, to increase margin profit, the importers buy on the market a product from another EU country, which is not exactly the same (impurities, concentration, coformulants ...)

Second : counterfeit the import parallel label so that both labels on the double labelling drums are counterfeited;

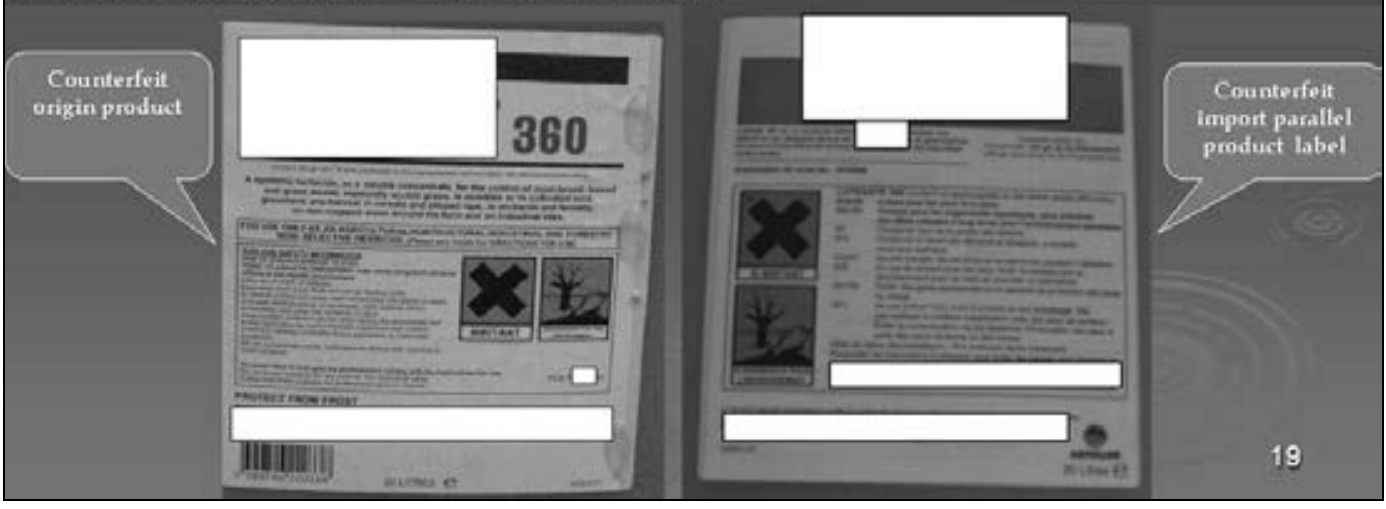

The counterfeit of the import parallel label is smaller and is written with different block letters. It even displays spelling mistakes like "glyphosphate" instead of " glyphosate »

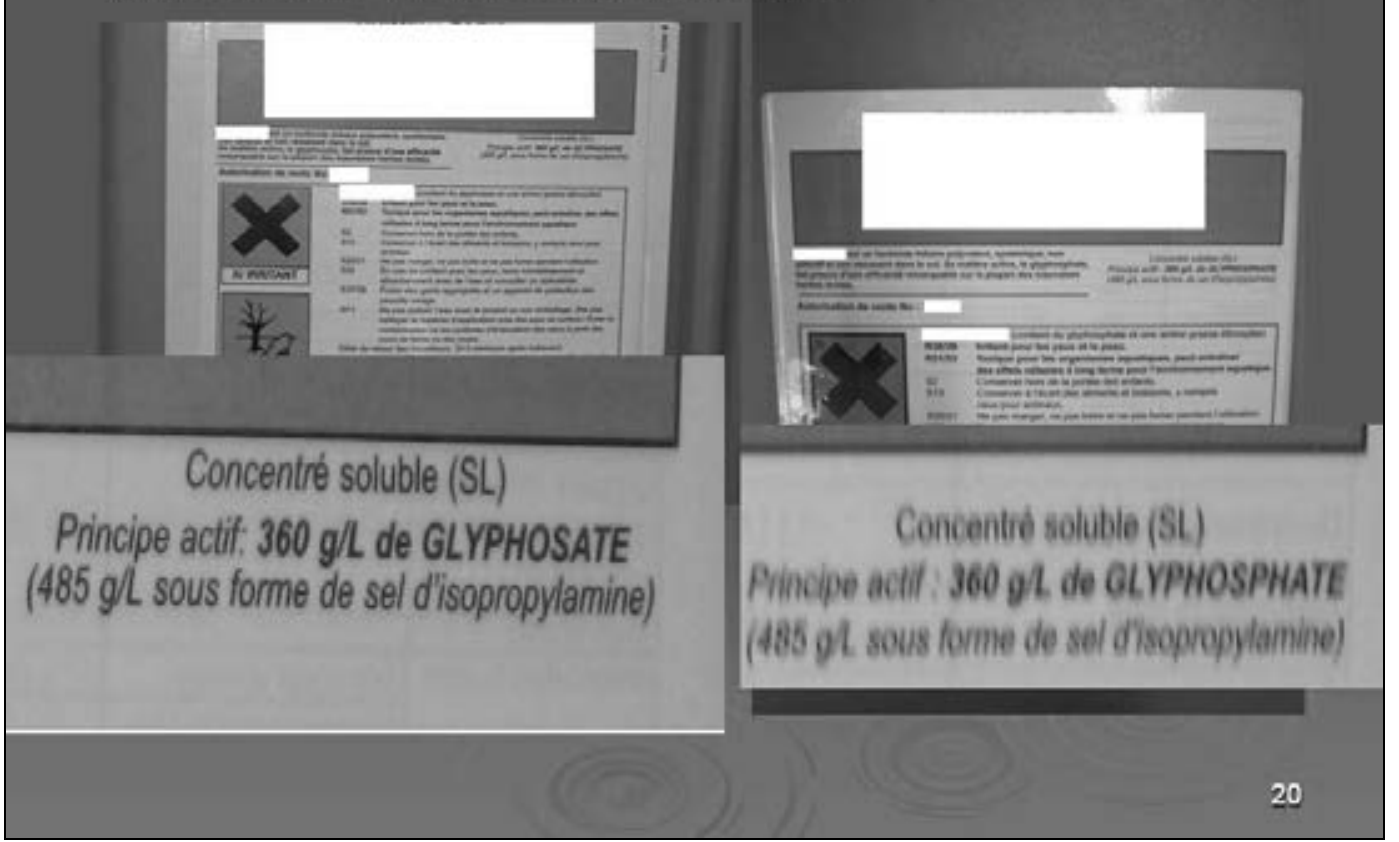


Third: The product which is sometimes formulated in Europe by a chemical manufacturer is packaged without a standard label, just showing the name of the active substance. Labelling operations are done mostly on demand in the country of destination for example during a stop in the transportation company warehouse.
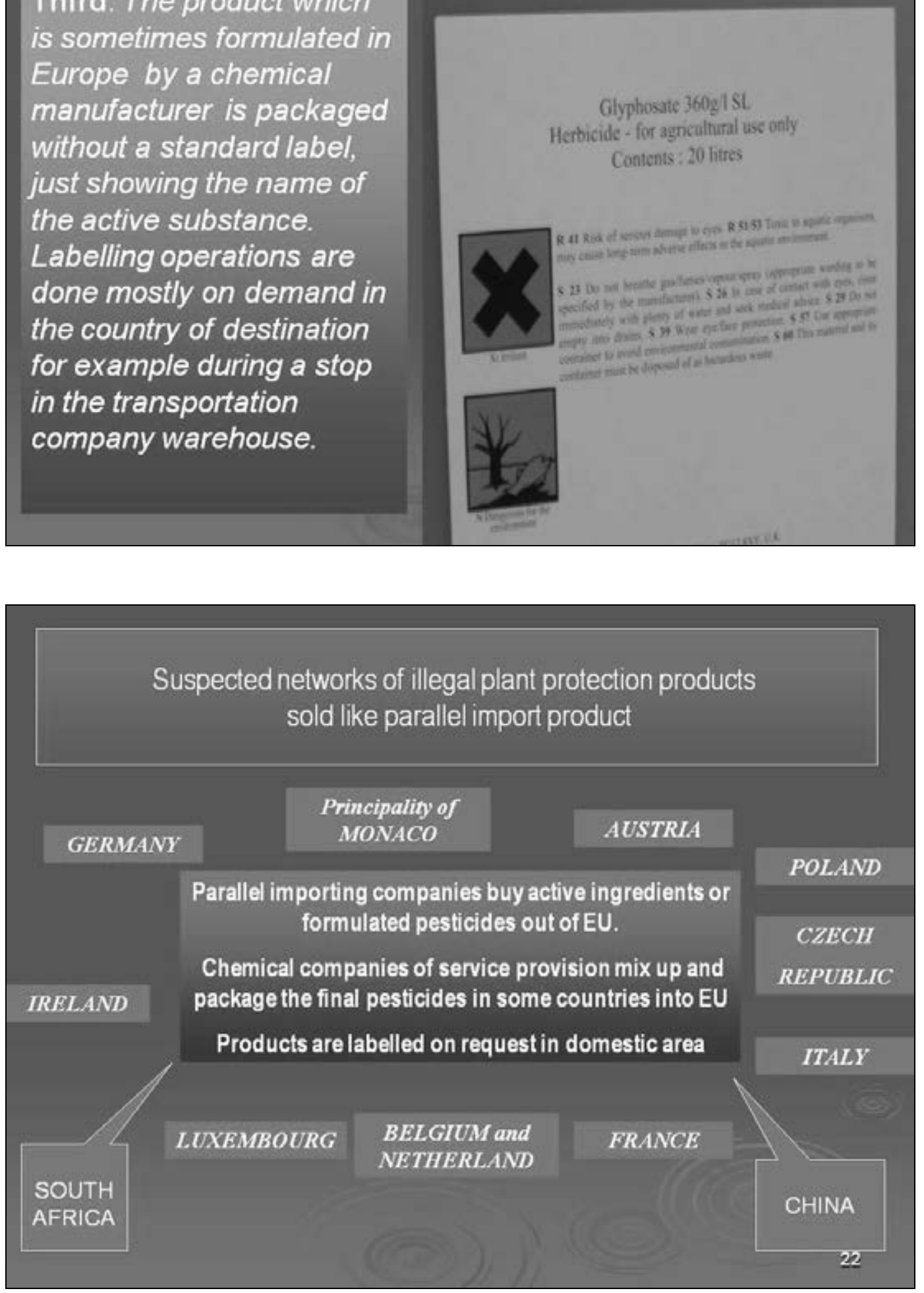


\section{EVOLUTION IN WAYS OF COUNTERFEITING}

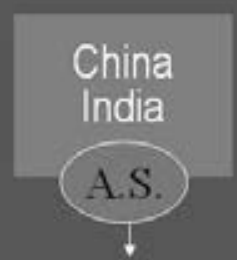

Pesticides Formulation without final label before transport

The product is labelled in the destination country by a wholesaler or a contracting company

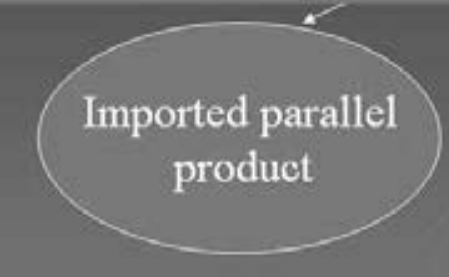

\section{Future undertakings for control improvement in EU}

D. Improve the control tools : continuous update database of PPPs ( and parallel import PPPs) in each member state of EU with the same standard data

> Regular meetings with representatives of competent authorities to establish cooperation and get more effective exchange of informations about counterfeit

> harmonize the administrative and financial sanction in case of infringements

> Further development of the administrative inspections:

- Controls towards final users, focusing mainly on buying groups or associations of buyers

- Controls toward wholesalers and logistic transport warehouses

- Increased level of information to the distributor 


\title{
Practical means for better fighting counterfeit and illegal trade
}

$>$ No repackaging awaiting the improvement of traceability in trade and require the origin manufacturer label on the package

> Ban the batch number stickers and require an inkjet batch on the drum

$>$ Print the batch number of the origin product on the supplier invoice

> Plan a post-registered survey on PPPs chemical content

- Introduce a more effective anti-counterfeit protection by industry

\section{Seminar}

Risk Reduction through Prevention, Detection and Control of the Illegal International Trade in Agricultural Pesticides

PARIS, Wednesday 19 May 2010

$O E C D$

\section{THANK YOU FOR YOUR ATTENTION}

\author{
maurice.boureau@agriculture.gouv.fr \\ Phone: + 33673670935 \\ herve.gillet@agriculture.gouv.fr \\ Phone: +33 673670937
}


Presentation 7

European Commission

Jürgen Helbig

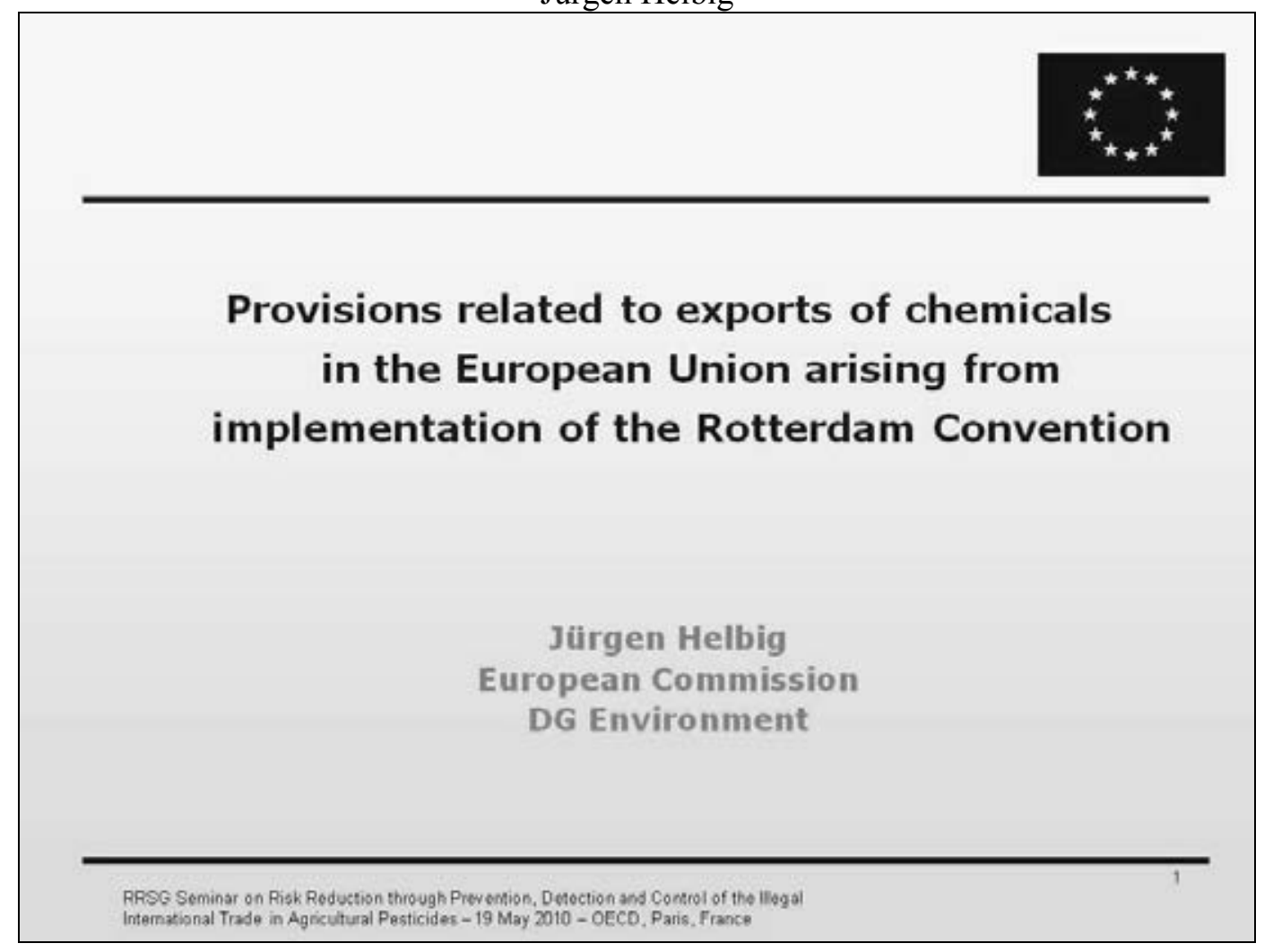

\section{Content}

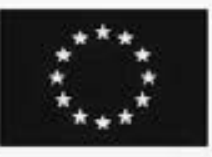

1. Obligations under the Convention

2. Responsibilities in the $E U$

3. Chemicals

4. Provisions on exports

5. Provisions on imports

6. Controls

7. Monitoring and reporting 


\section{Rotterdam Convention}

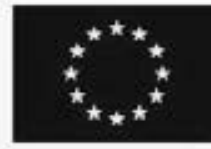

Key trade related obligations are:

Exporting Parties shall notify importing Parties the export of banned or severely restricted chemicals.

All Parties shall establish import decisions for chemicals listed in Annex III to the Convention.

Exporting Parties shall ensure compliance of exporters with the import decisions.

\section{Regulation (EC) 689/2008}

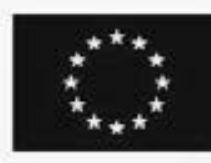

Regulation (EC) No 689/2008 of the European Parliament and of the Council concerning the export and import of dangerous chemicals implements the Rotterdam Convention on the Prior Informed Consent Procedure for Certain Hazardous Chemicals and Pesticides in International Trade
(OJ L 204, 31.7.2008, p. 1-35) 


\section{Regulation (EC) 689/2008- Responsibilities in the EU}

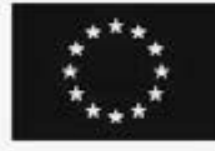

\section{European Union}

II European Commission is common DNA for EU, working in close co-operation with DNAs of Member States.

European Commission manages the database EDEXIM.

- The European Commission establishes PIC notifications in consultation with and also on behalf of Member States.

= European Commission co-ordinates EU participation at international level (e.g. CoP, CRC etc.).

\section{Member States}

II Each Member State has a Designated National Authority (DNA) responsible for implementation, e.g. processing of export notifications and requests for explicit consent.

= Customs are responsible for export/import controls.

\section{Regulation (EC) 689/2008- Chemicals}

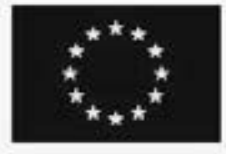

\section{Chemicals covered:}

Chemicals that are banned or severely restricted (BOSR) in the European Union

- Chemicals that are listed in Annex III to the Rotterdam Convention

The Regulation establishes subcategories of "convention use categories" so as to cover more chemicals 
Regulation (EC) 689/2008-

Chemicals

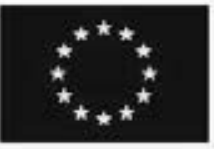

The Regulation differentiates 3 categories of chemicals:

- Chemicals banned or severely restricted (BOSR) in a subcategory of a convention use category (Annex I Part 1)

- Chemicals banned or severely restricted (BOSR) in a convention use category (Annex I Part 2)

Chemicals included in Annex III of the Convention (Annex I Part 3)

\section{Regulation (EC) 689/2008- Provisions on exports}

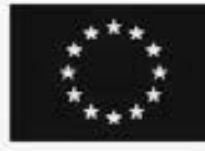

Lists of chemicals and obligations:

Annex I Part 1 - chemicals subject to export notification (BOSR within the EU in at least a use subcategory)

Annex I Part 2 - chemicals subject to the explicit consent procedure (BOSR within the EU in a Convention use category)

Innex I Part $3=$ Annex III of Convention, i.e. chemicals subject to the PIC procedure 


\section{Regulation (EC) 689/2008- \\ Provisions on exports}

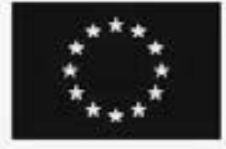

\section{The export notification}

Requirement applies to chemicals in Part I of Annex I exported to any country and irrespective of use.

Annual notification by each exporter before first export of a chemical (information as per Annex II). Notification from the first exporter each year forwarded by Commission.

In Central register of notifications on EDEXIM.

\section{Regulation (EC) 689/2008- Provisions on exports}

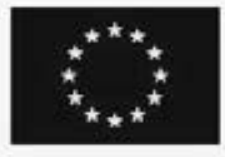

The explicit consent procedure

is applied for all chemicals that are banned or severely restricted (BOSR) in a convention use category (Annex I Part 2),

is applied for all PIC chemicals for which no import decision from the importing country is published (Annex I Part 3),

requires the explicit consent of the importing party before the export can take place. 


\section{Regulation (EC) 689/2008- \\ Provisions on imports}

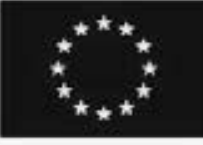

The European Commission adopts decisions to establish EU import responses for chemicals subject to PIC procedure on basis of existing EU legislation.

1 If necessary, consideration of EU measures to deal with risks presented by chemicals concerned on the basis of the DGD distributed by the Secretariat.

European Commission receives export notifications from third countries and informs Member States and publishes them on EDEXIM.

Regulation (EC) 689/2008Controls

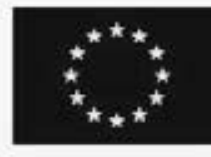

Authorities in Member States such as DNAs and customs offices are responsible for controlling and monitoring exports and imports of chemicals listed in Annex I.

Targeted and co-ordinated control of compliance, with regular reporting by Member States. 


\section{Regulation (EC) 689/2008-} Controls

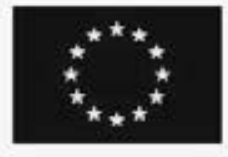

Tools for the control of exports:

Reference Identification Number (RIN)

Customs declaration

EDEXIM (European Database Export Import of Dangerous Chemicals)

TARIC (Integrated Community Tariff) database flagging for custom officers who then can check in EDEXIM database.

\section{Regulation (EC) 689/2008-}

\section{Controls}

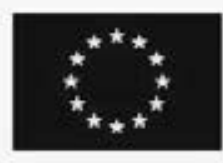

The Reference Identification Number (RIN)

is assigned for each export of a chemical in Annex I upon introduction of the notification in EDEXIM,

will be activated if all requirements are met, has to be provided on the customs declaration, is used by custom officers for checking the approval status of the export in EDEXIM database. 
Regulation (EC) 689/2008-

Monitoring and reporting

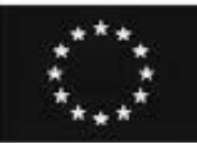

- Exporters and importers to provide annual reports on quantities of chemicals traded.

- Member States to forward annual national reports to European Commission, which publishes an overall summary on EDEXIM.

Regulation (EC) 689/2008Information

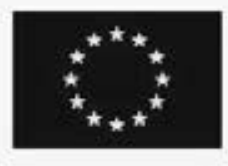

Exhaustive information on implementation, legal aspects and chemicals is available at: http://ec.europa.eu/environment/chemicals/pic/ index.htm http://edexim.jrc.ec.europa.eu 
ENV/JM/MONO(2011)6

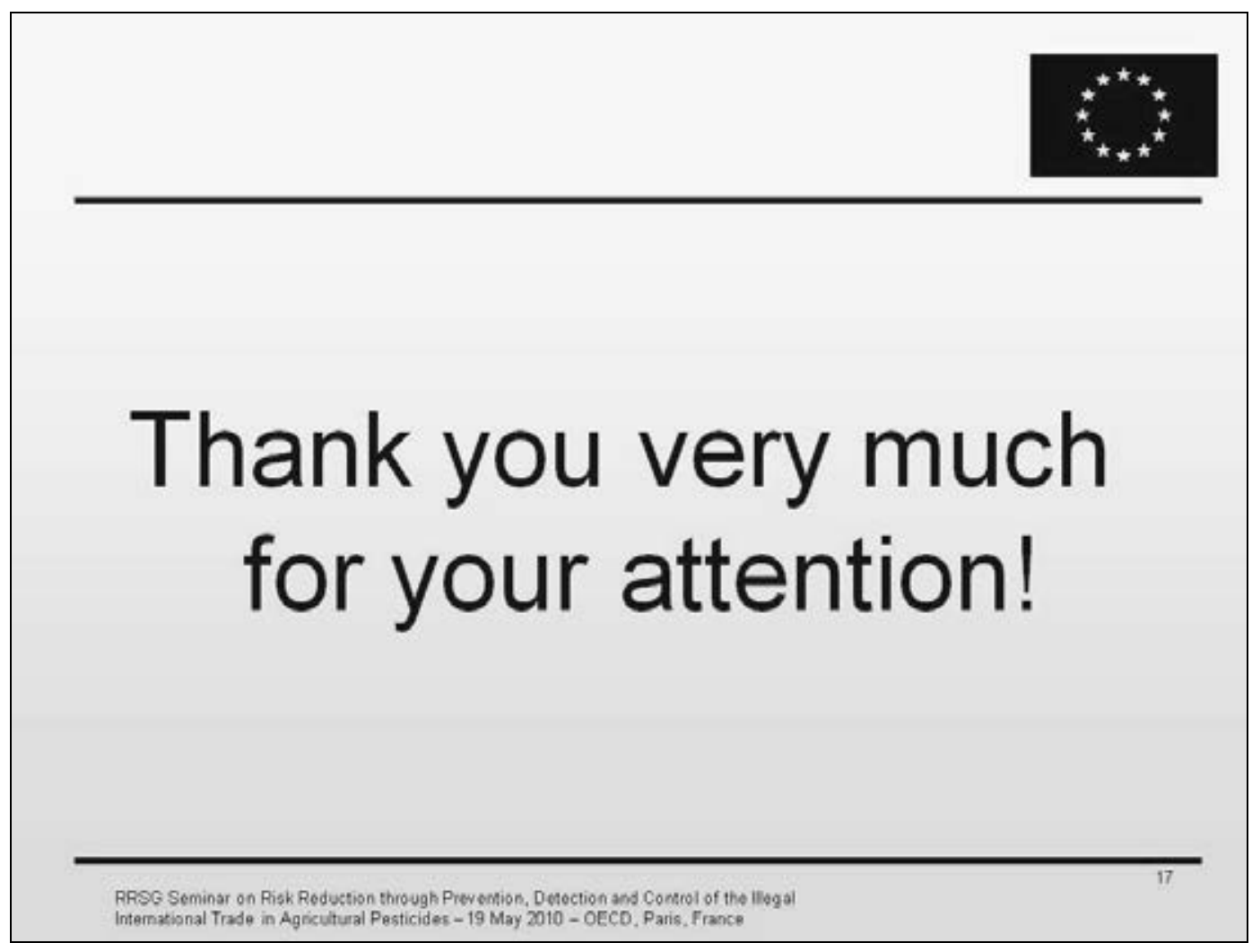


Presentation 8

CropLife International

D'Arcy Quinn
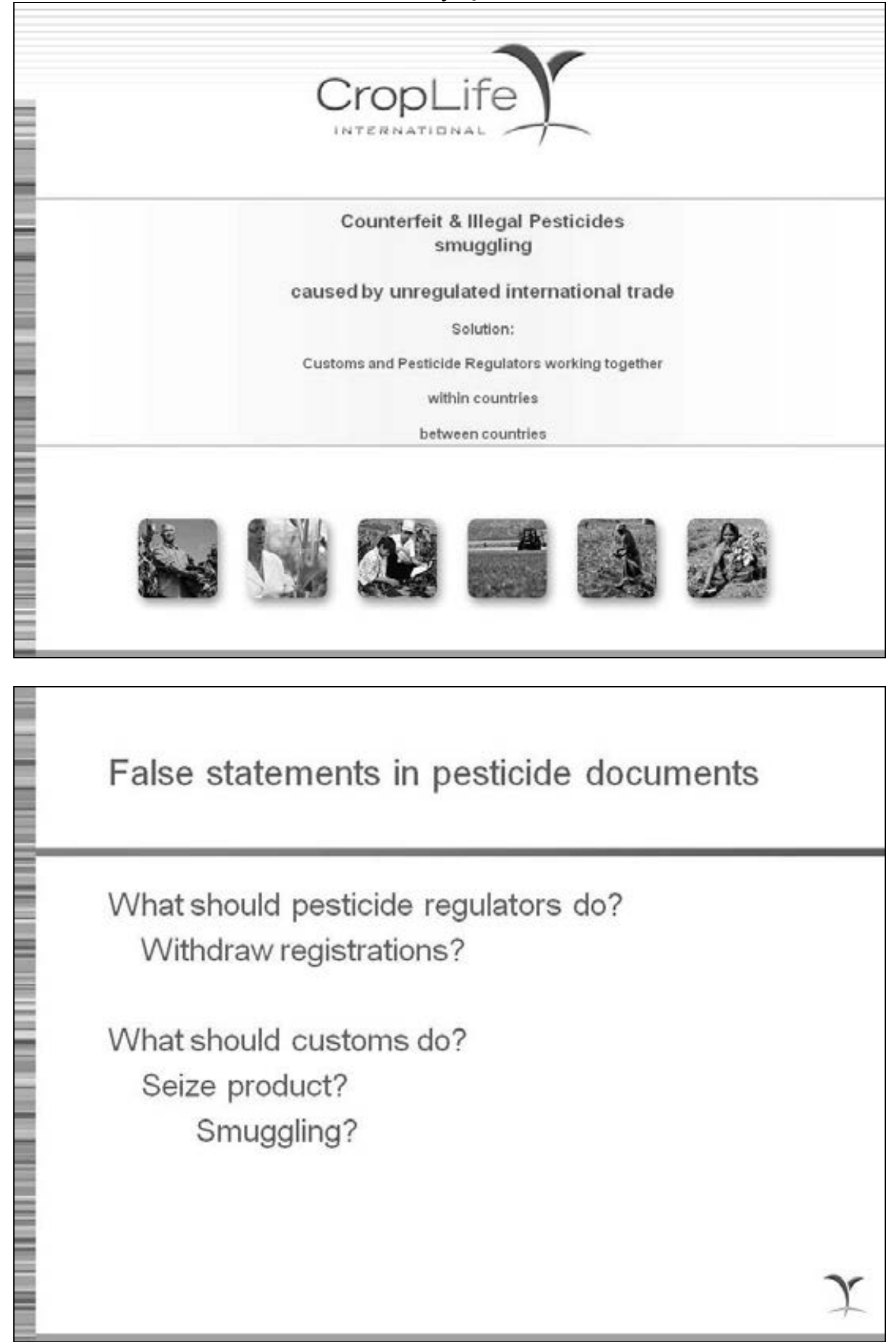


\section{International shipping - customs}

Crisis at import - pesticide documents

Issue: No links between export \& import documents for pesticides

Solution: Link shipping documents (export to import)

Import customs need to know if the active ingredients / pesticides are:

- legal

- registered

- what is stated on the import documents (!)

- from legal exporters

- from legal factories

Registered with ICAMA

SUPPORT ICAMA regulations and database!

\section{Pesticide regulators}

Crisis: "Fake factories" making pesticides

Issue: Factories don't always exist

Solution: Transparency in regulatory documents

Do the regulators know the Al manufacturer?

- Factory registered with ICAMA?

- Do regulators inspect the factories?

Support ICAMA regulations and database! 


\section{Responsibility}

Who are the "Counterfeiters"?

Who is primarily responsible (liable) for counterfeit?

The actual Counterfeiters (obvious!)

Are they the only persons responsible?

\section{Responsibility}

\section{Exporters of active ingredients to counterfeiters}

Exporters: 'We didn't know clealing with counterfeiters!' 'Notour problem'

And exporters continue to ship Al to counterfeiters.

Issue: 'Knew or Should Have Known' exporting to counterfeiters?

ExporterSolution: Know Your Customer-do not ship to counterfeiters

Legal trend of third party liability for counterfeits:

e-Bay cases

Tourists in airports

Bankers

Cigarettes

Landlords

Exporters of components for counterfeits?

Who will pay for storage and destruction costs of counterfeit pesticides and Als? 
Educate and work with exporters - Shanghai Export Fairs

'Know Your Customer'

Initiate KYC program in China with exporters

Do not ship Al to counterfeiters in other countries

Government support from ICAMA

Al exporters might be responsible for:

- Storage/destruction costs

- Reputation damage to exporting country

- Potential arrest and prosecution

\section{How to avoid shipping Al to counterfeiters}

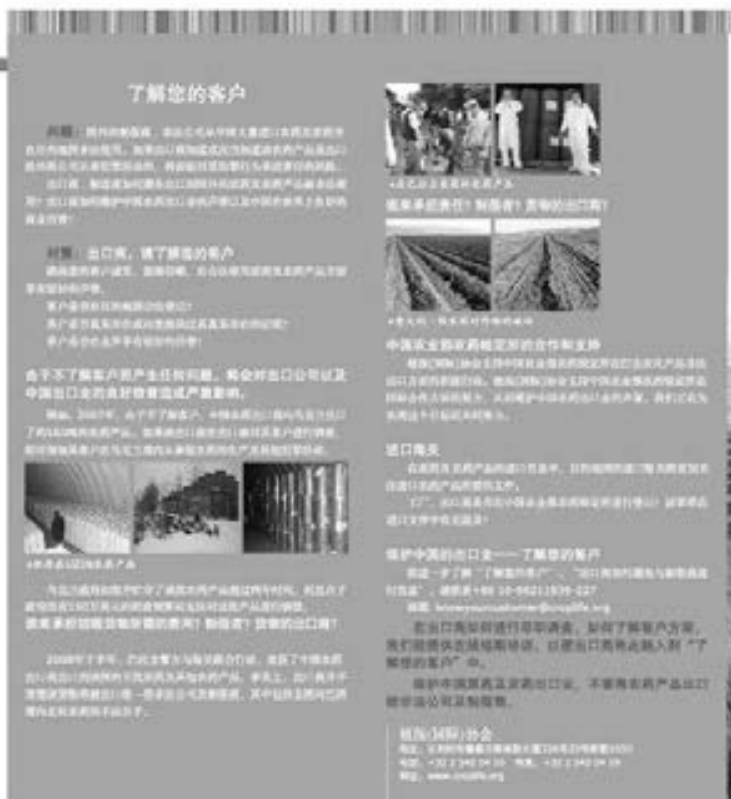

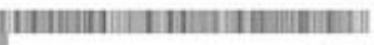

gover

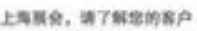

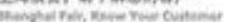

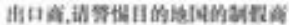

Eporten Dewiry of Countartaten in the

Destinatien Country 

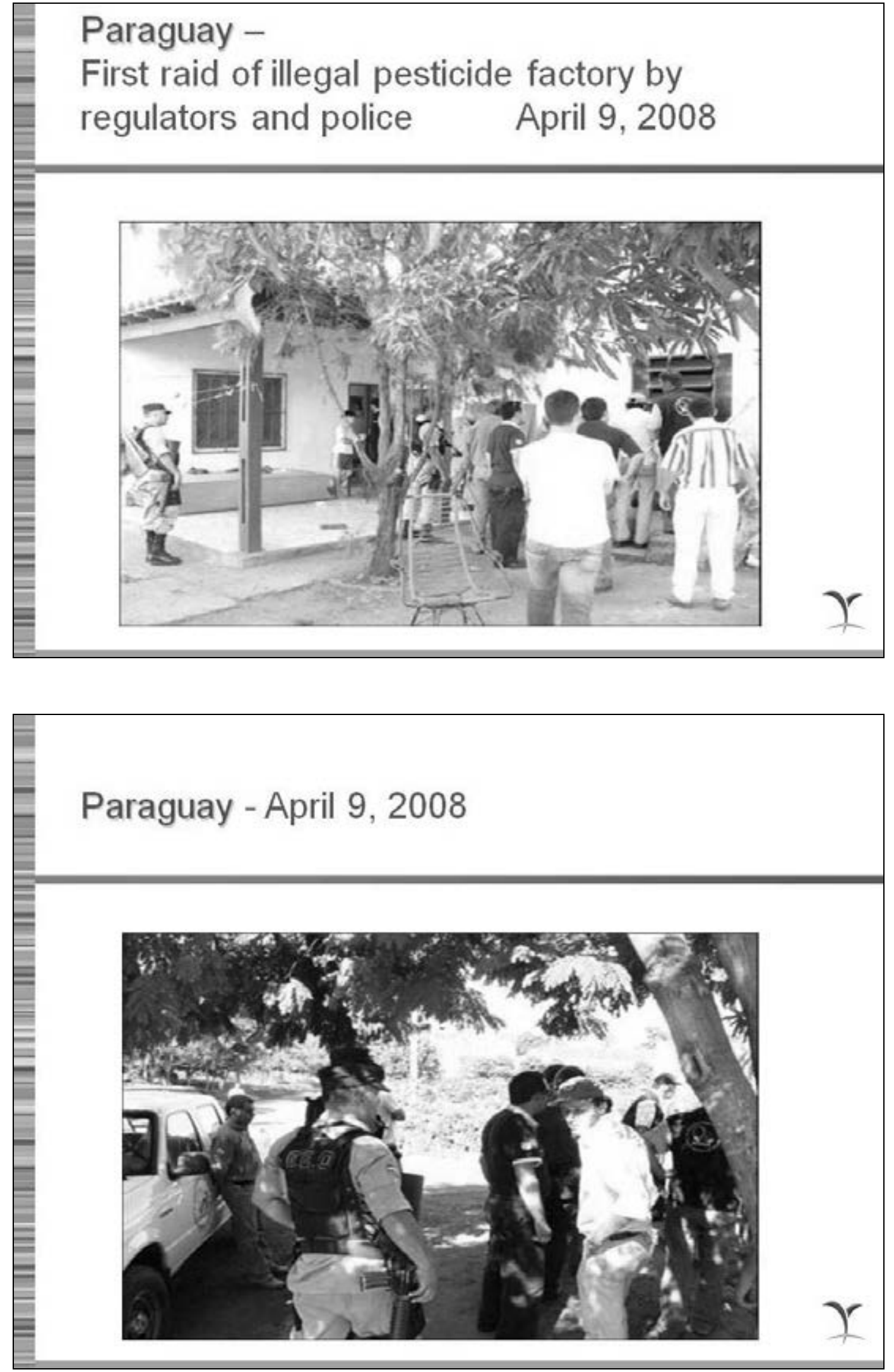

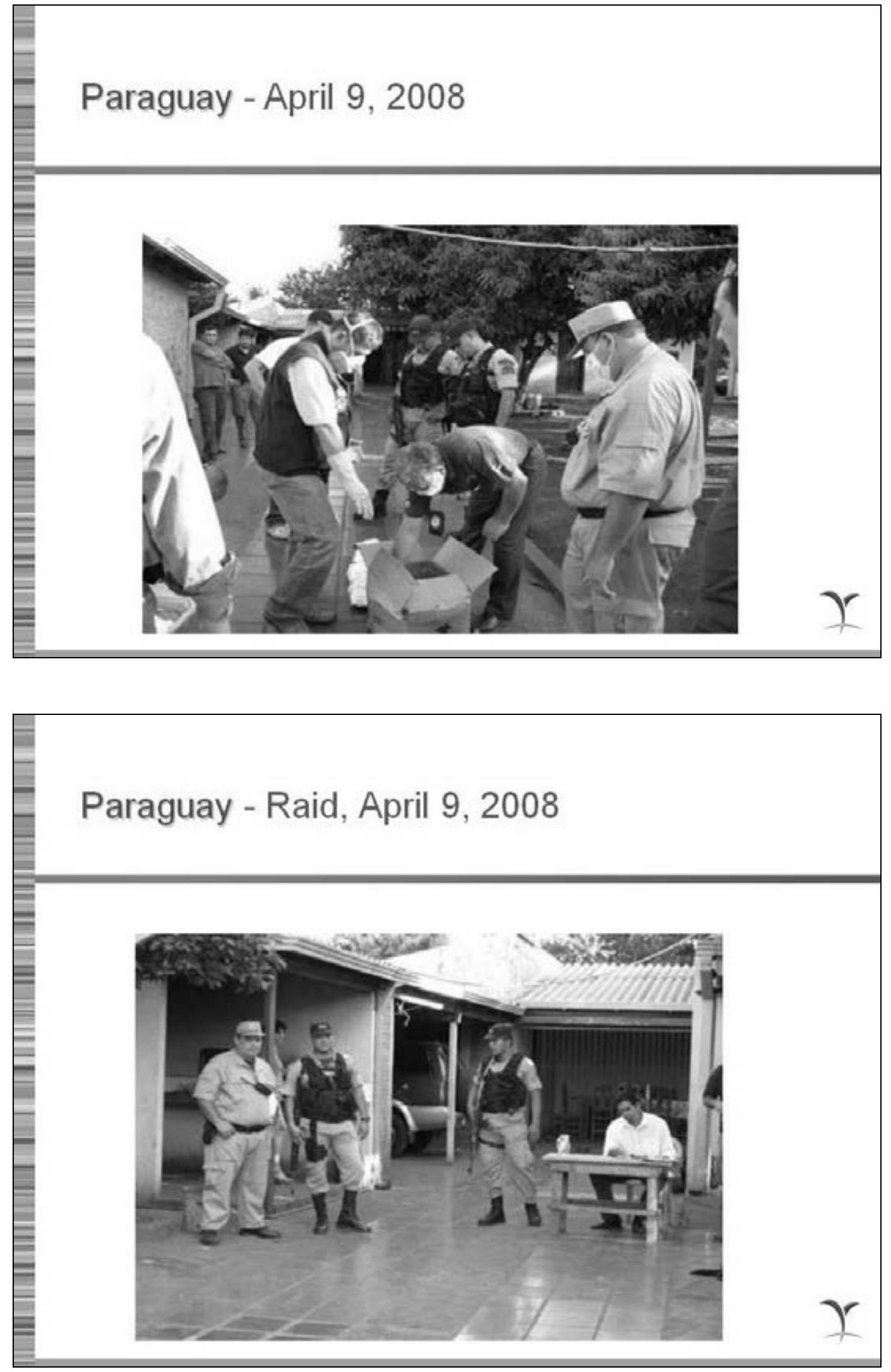


\section{Paraguay - customs action}

Seizure: 16,000 Liters Glyphosate 41\%, Port of Villeta

19 Nov 08

$\checkmark$ Container contents fraudulently declared as Imidazole

$\checkmark$ Seizure conducted by the Unidad Tecnica Especializada (UTE)

Facts:

- EXPORTER

- Registered exporter in ICAMA. NOT manufacturer

- Commercial invoice NOT authentic

- EXPORTER website advertises the sale of Glyphosate

- EXPORTER participated in the Shanghai Export fair

Issue: Who falsified the shipment documentation?

Answer: The importer

\section{Paraguay - customs seizure of illegal AI}
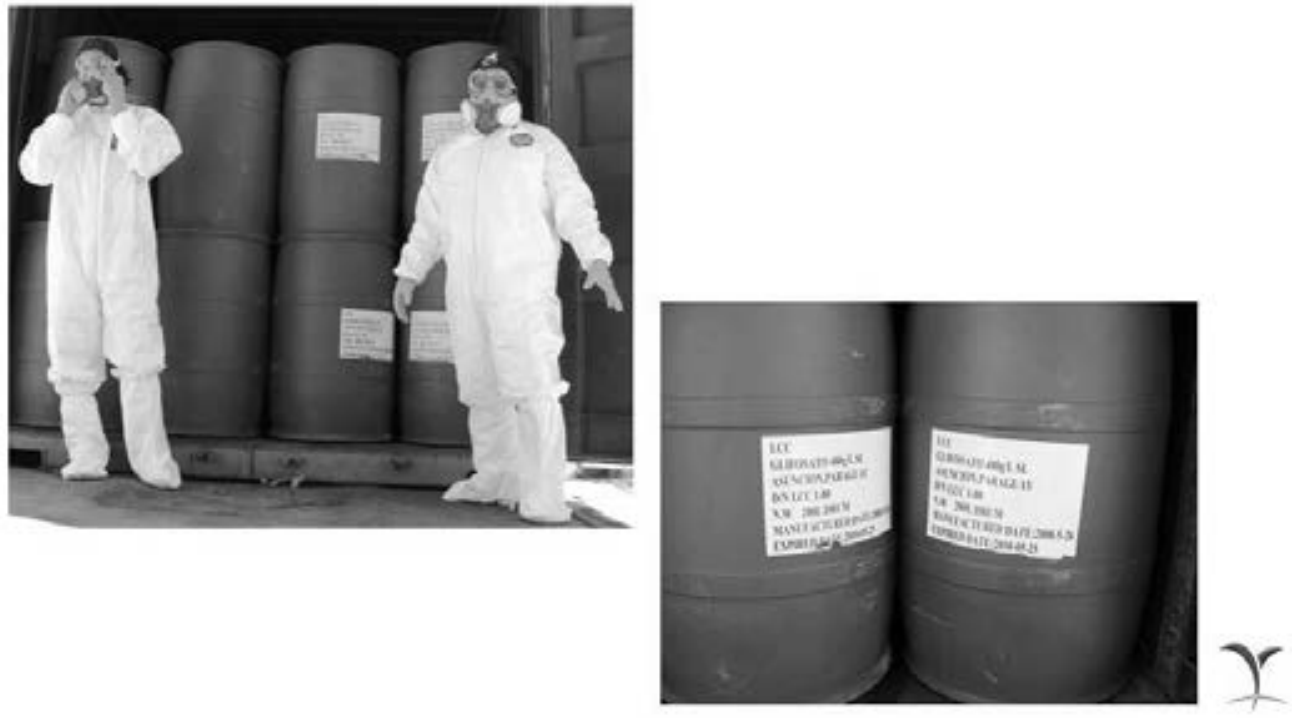
ENV/JM/MONO(2011)6
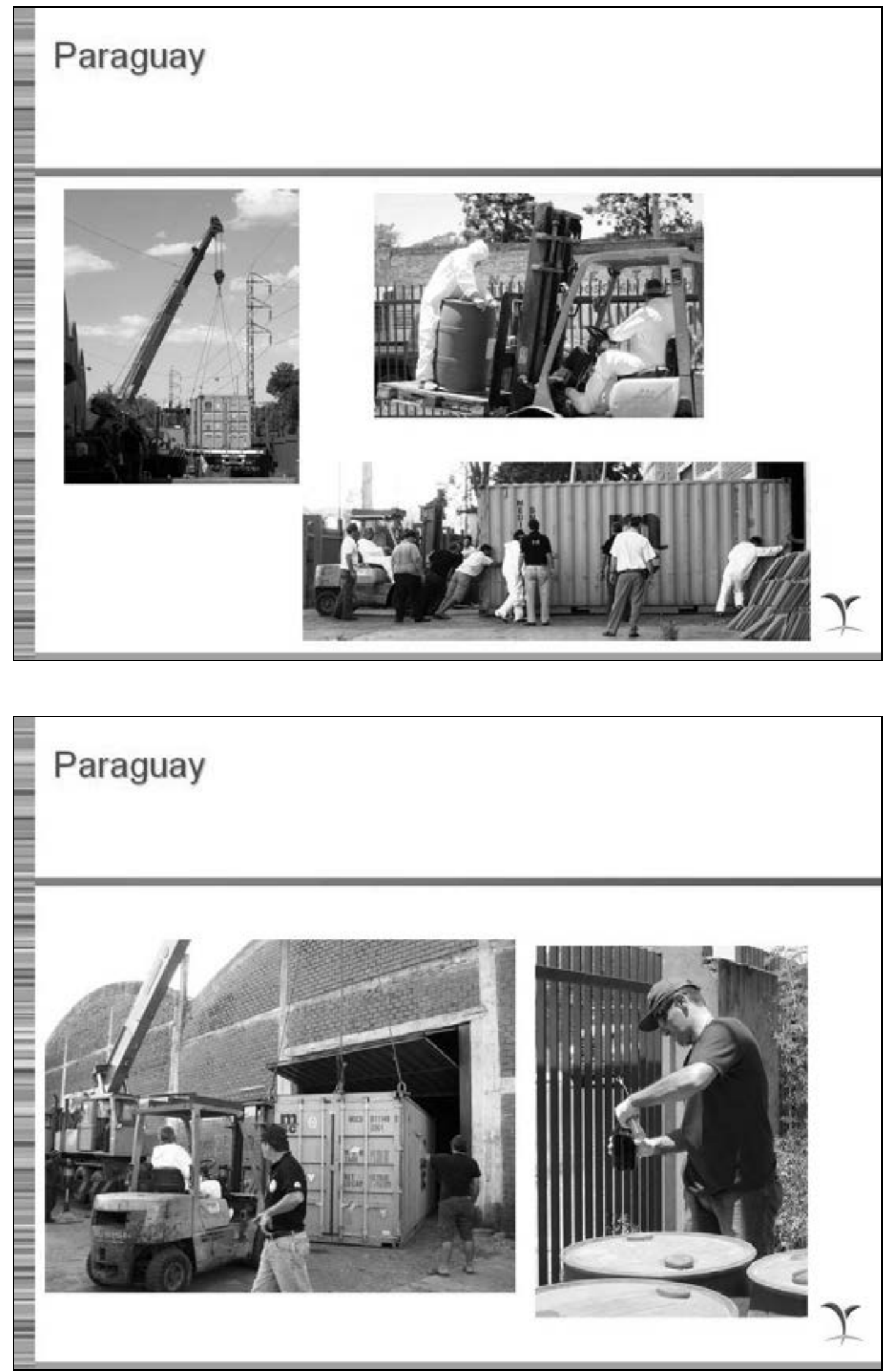


\section{Paraguay -media coverage}
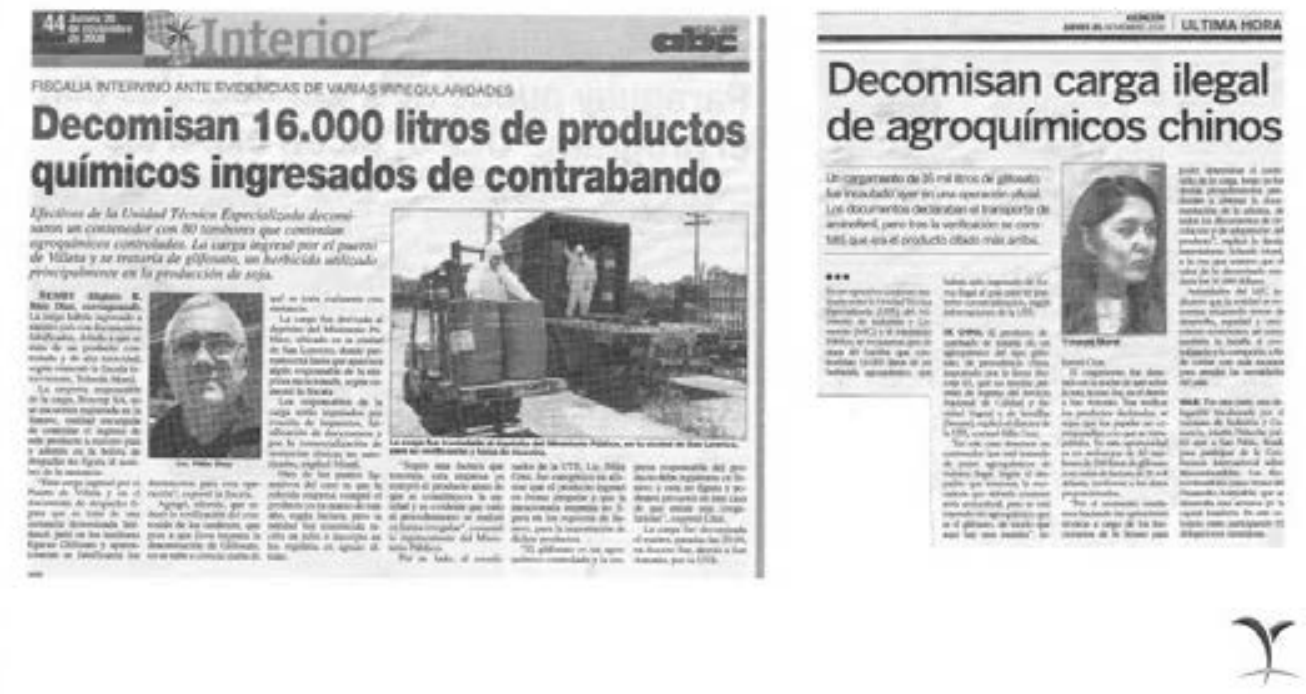

\section{Paraguay - customs action}

Azoxistrobina (AZ) Disguised as Precursor Chemical 25 Nov 08

$\checkmark$ Information received from governmentpertaining to a suspect shipment.

$\checkmark$ Declared as (E)-2-(2-(6-Chloropyrimidin-4-Yloxy)Phenyl)-3Methoxyacrylate, but suspected to contain AZ.

$\checkmark$ Retention of product carried out by Prosecutor.

$\checkmark$ According to "lab test" chemical was NOT AZ, but precursor chemical which requires no ICAMA or regulatory authorization.

Facts:

- Exporter listed in the internet as a clothing and shoe manufacturer, sent product to Paraguay by air via Miami.

- Commercial Invoice issued but companies do NOT exist.

- Sharp increase in counterfeiting of AZ related product thereafter! 


\section{Paraguay -media coverage}

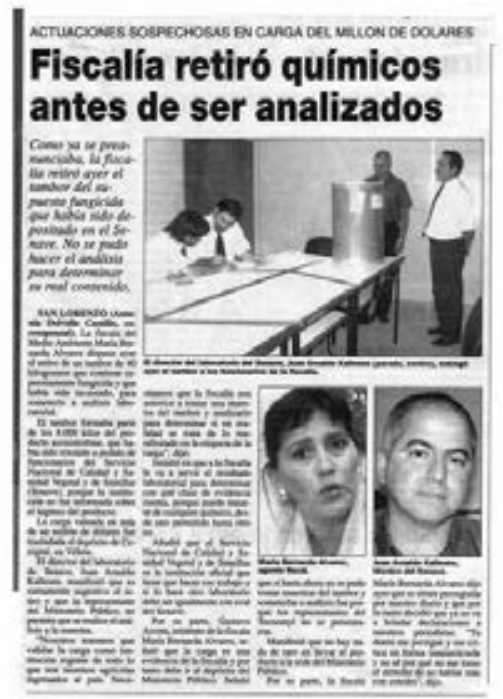

\section{Sontonam \\ ECONOMIAY YTSOCLOS \\ Una carga de un millón de dólares está retenida en puerto de Villeta} che In as
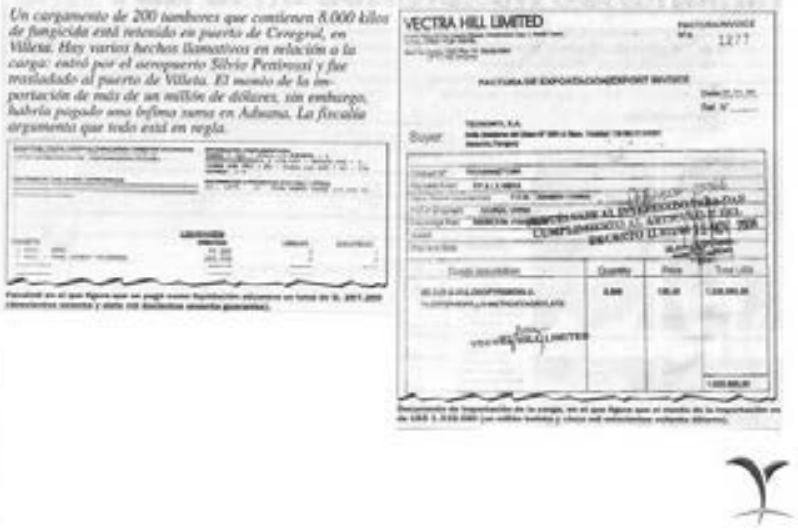

\section{Paraguay - customs action}

\section{Multi-Container Seizure}

\section{Dec 08}

$\checkmark$ Three containers seized following departure from the Port of Villeta, product imported by $X X X$ without pesticide regulatory authorization.

$\checkmark$ Containing: 23,520 kilos of Methomyl $90 \%, 3,500$ kilos of Flutriafol $80 \%$, and 1,000 kilos of Imazethapyr $70 \%$

$\checkmark$ Seizure conducted by the Unidad Tecnica Especializada (UTE)

Facts:

- NO exporter or shipper declared on shipping documentation

- Three manufacturers listed on packaging:

- TaiAn Tianyi Chemical Co. Ltd, China Continental (Methomyl)

- NO ICAMA registration

- Shangyu Nutrichem Co. Ltd.. China Continental (Flutriafol)

- NO registrations in ICAMA for Flutriafol

- Pilot Plant of Shenyang Research Institute of Chemical Industry, China

Continental (Imazethapyr)

- NO ICAMA registration 
ENV/JM/MONO(2011)6
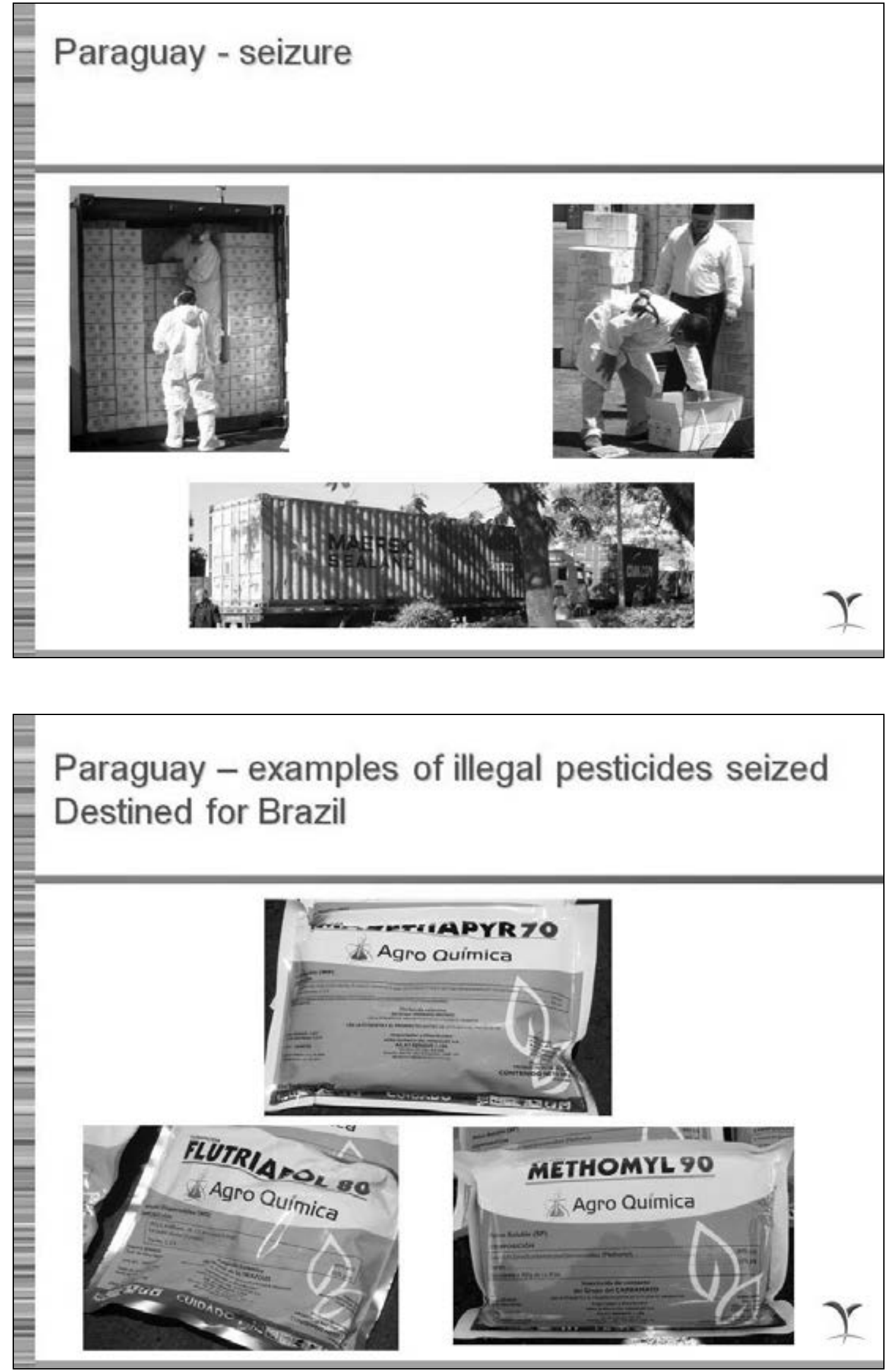

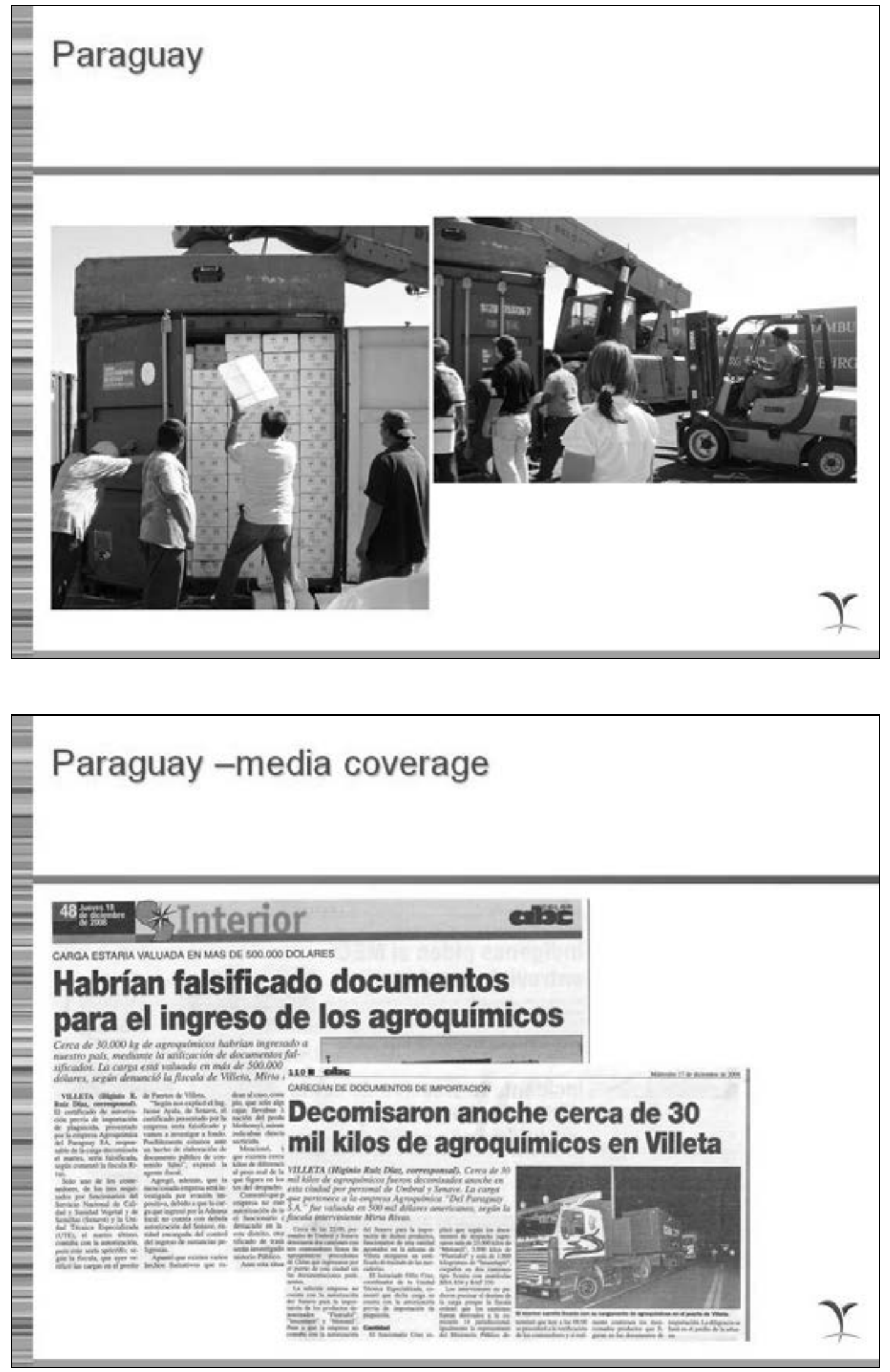
International trade

How to avoid Al being shipped to counterfeiters

\section{EXPORTERS $\rightarrow$ Know Your Customer}

IMPORTERS $\quad \rightarrow$ Shipping documents correct?

REGULATORS $\rightarrow$ Fraud in registration documents?

CUSTOMS $\quad \rightarrow$ Verify shipping documents

$\rightarrow$ Work with pesticide regulators

\section{EU}

imports of counterfeit pesticides

Lessons learned from Paraguay

Pesticide Documentation

European Union

Case study

January 2010 
- Hungarian customs

- German customs

- German BWA (Plant Protection)

- German Harbour Police

- Slovenia customs

- Lithuanian customs, police

- EUROPOL

- Homeland Security

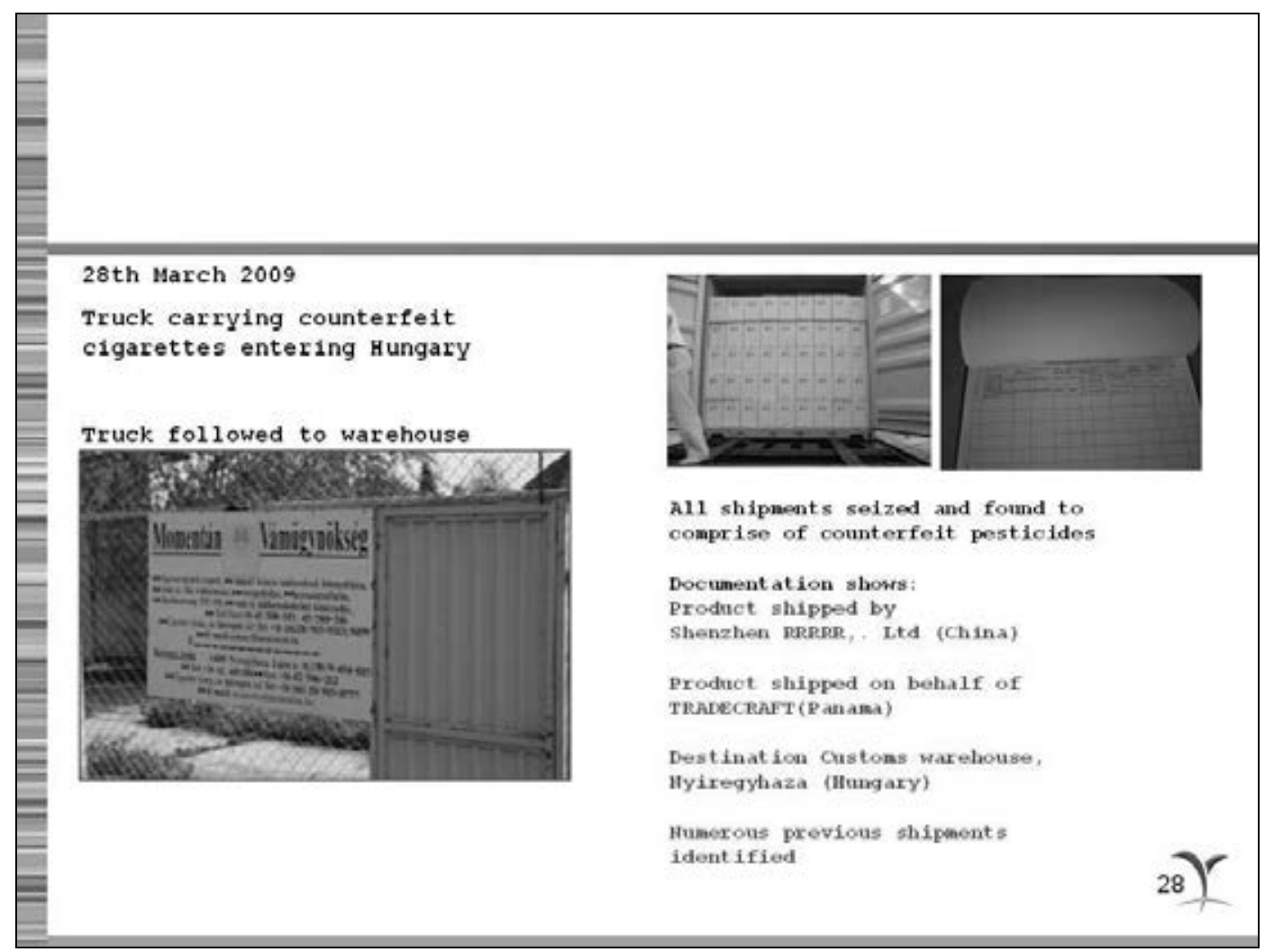


ENV/JM/MONO(2011)6
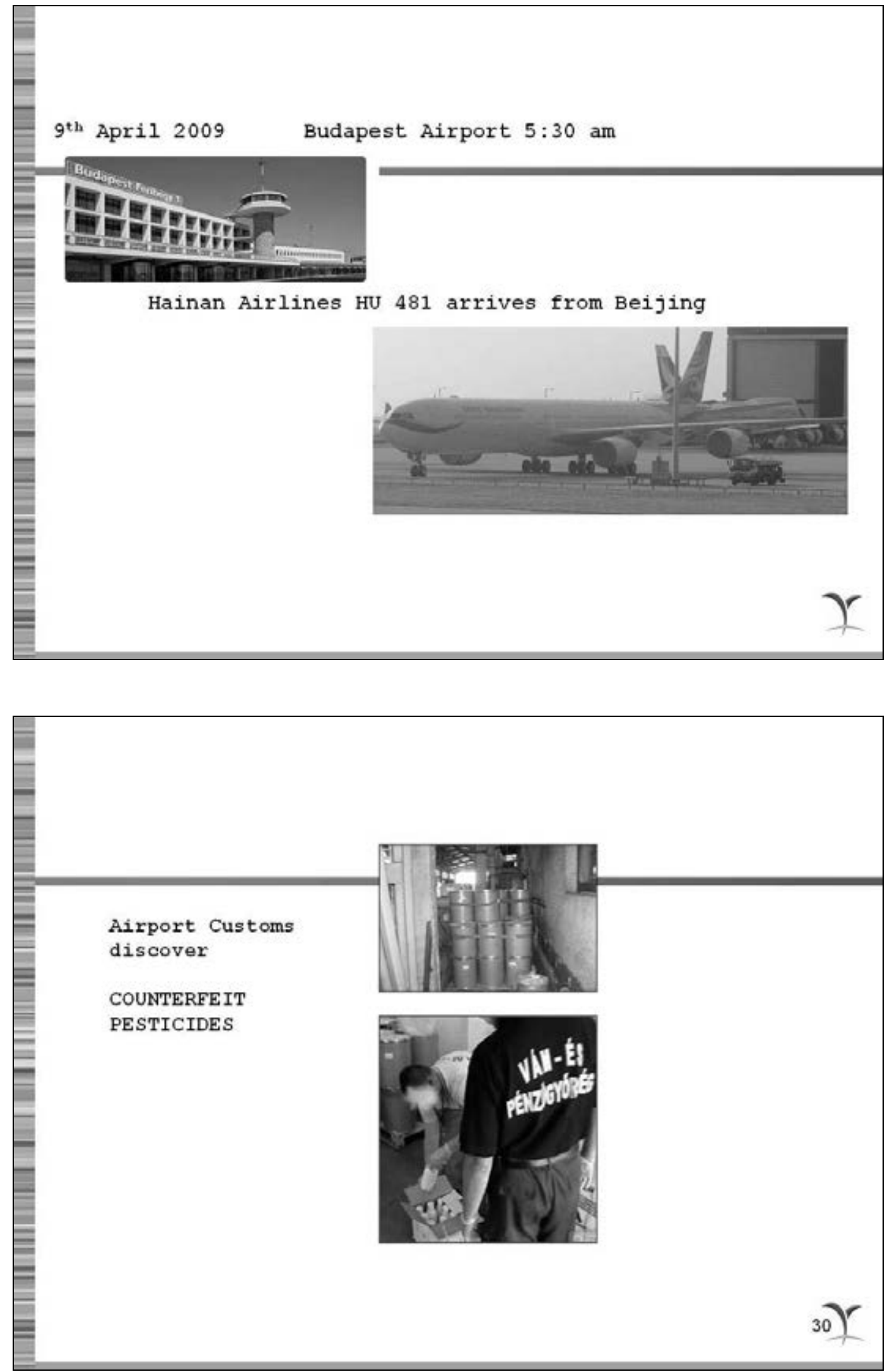

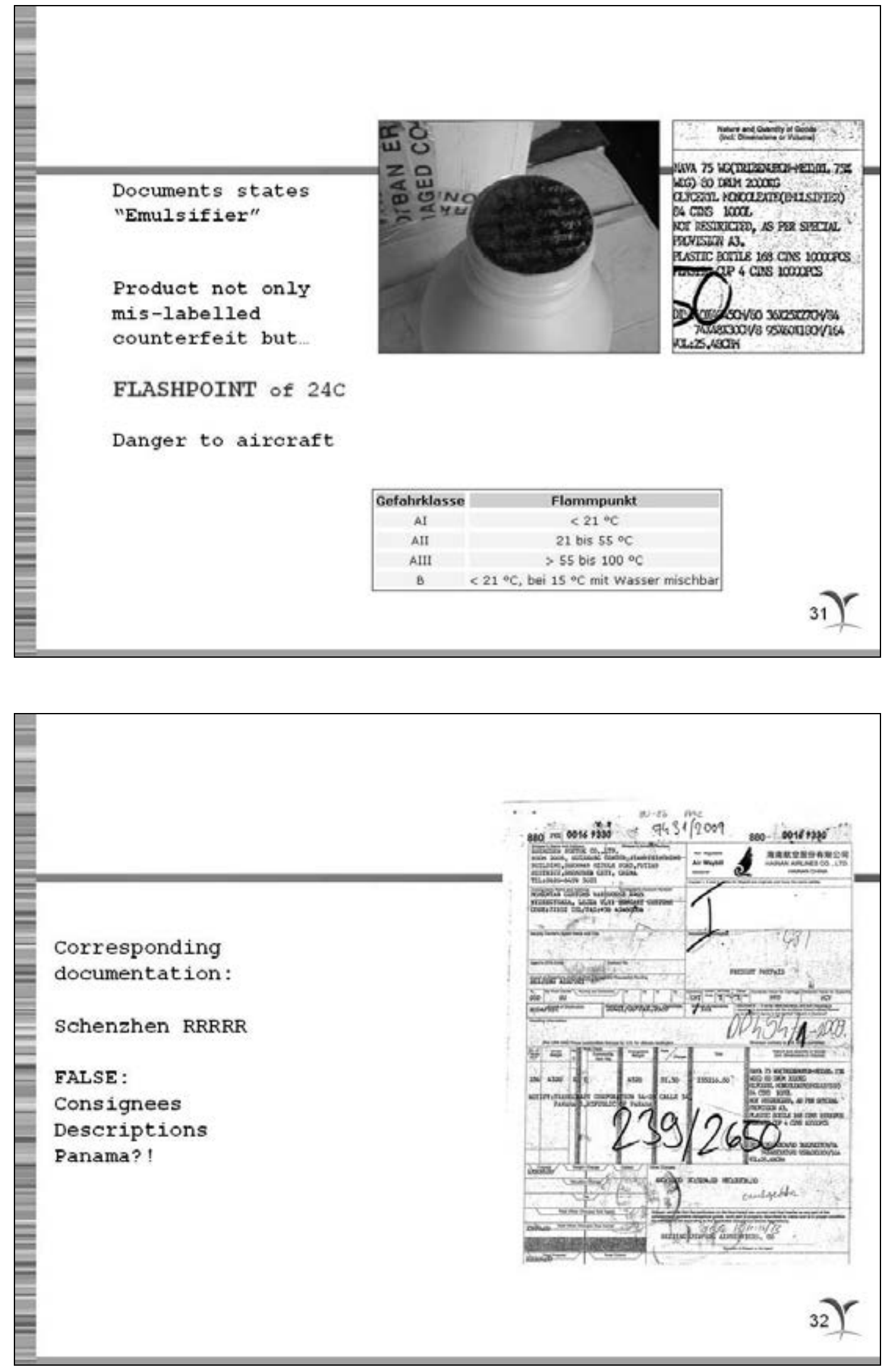

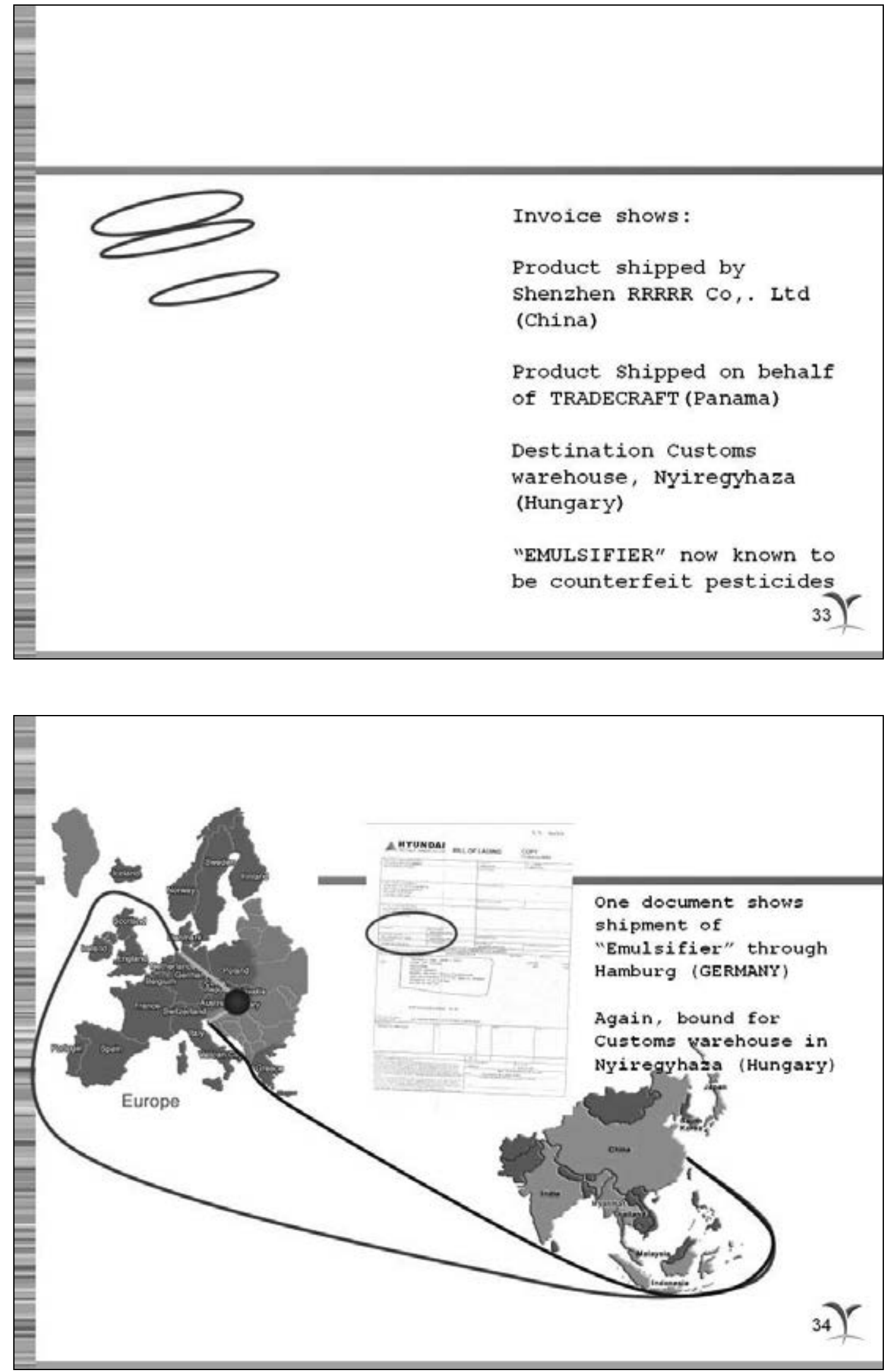
From documents: total known shipments of "emulsifier" only through Koper port: 283 tonnes (not seized!)
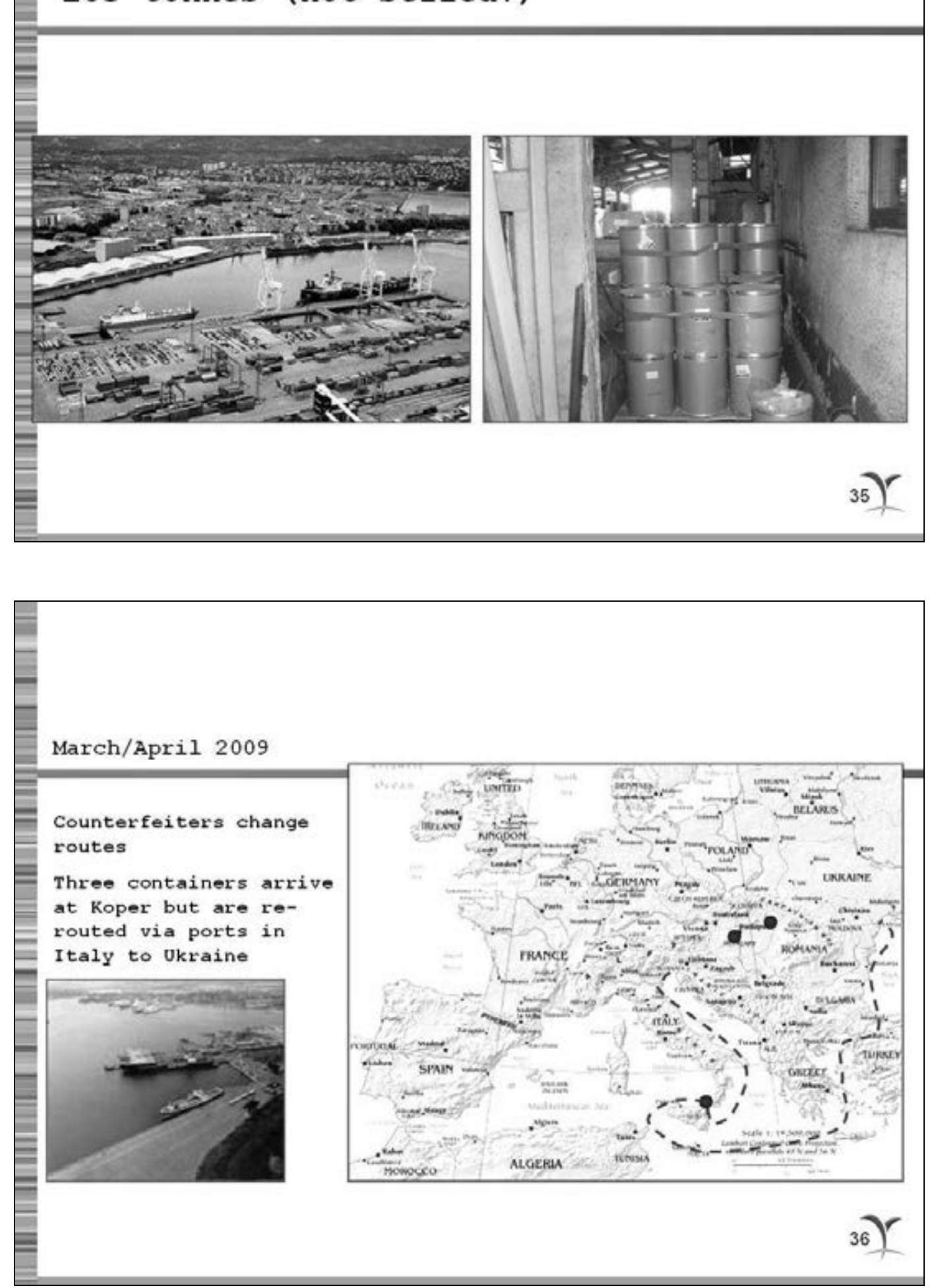

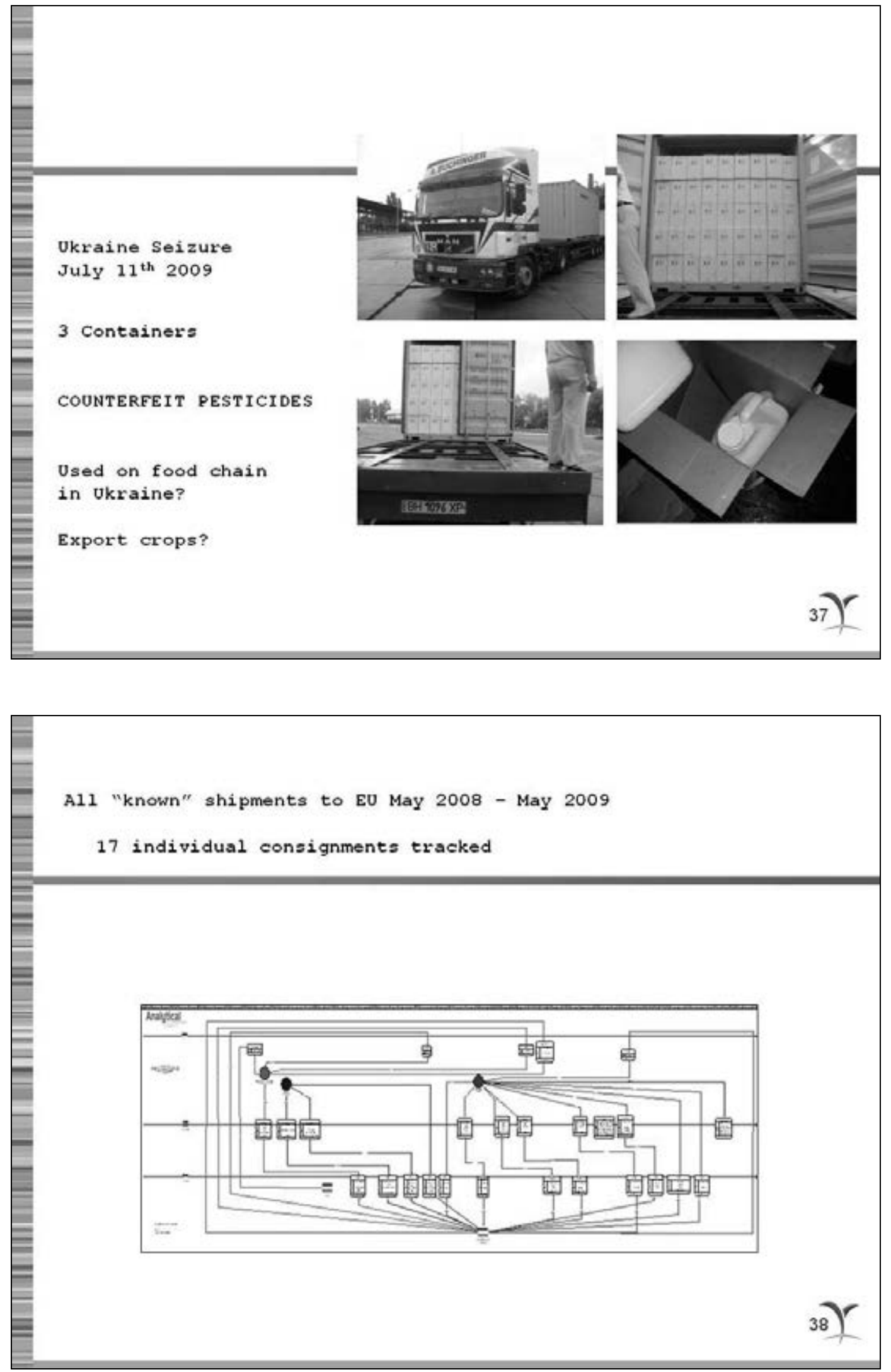
Exporter of counterfeit pesticides to the EU identified in Shenzhen, China:

Mr. $\mathrm{xxxxx}$

Manager Shenzhen RRRR Trading Co., Ltd. since November 2008

Previous employee of Shenzhen MMM Co.

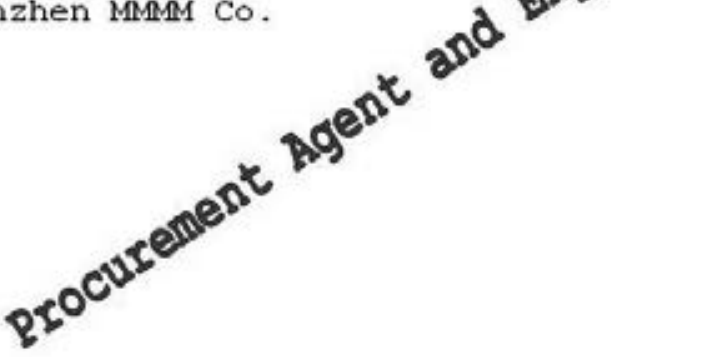

26 June 2009

Mr. xxxxx, exporter of counterfeits states:

- He hides the "real" pesticide name

He fully deals with customs to prepare for fake export license/documents

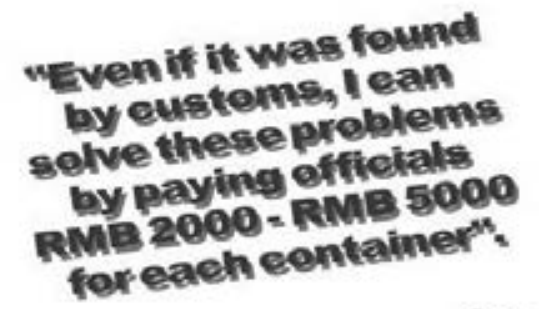

$40{ }^{r}$ 

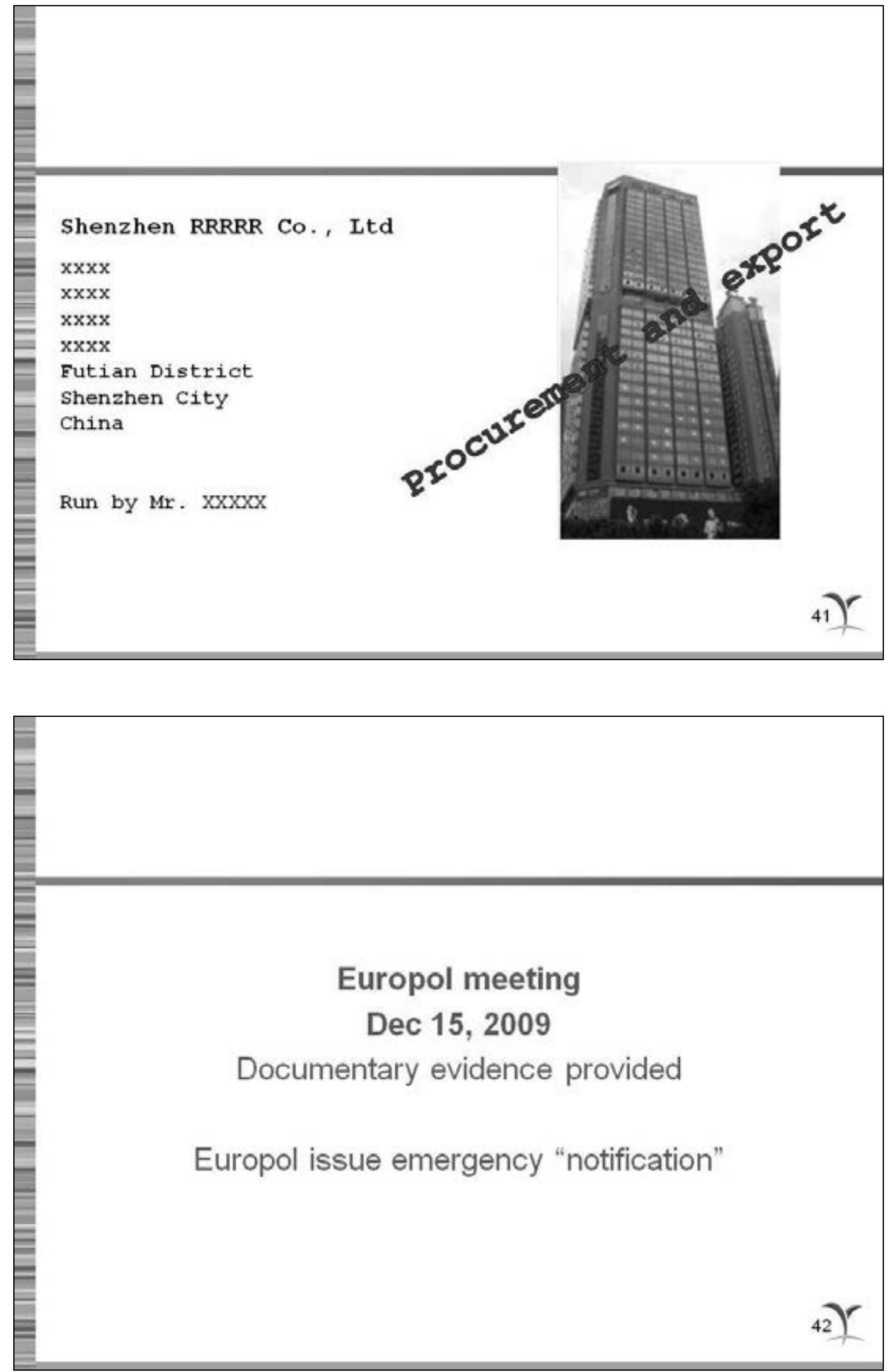


\section{Jan 4, 2010 \\ Hamburg seizure}

24 tons of counterfeit pesticides

Three containers

Shipping documents show:

Three containers of counterfeit pesticides

exported from China by one company:

Shenzhen MMMM

Prior employer of Mr. XXXXX 

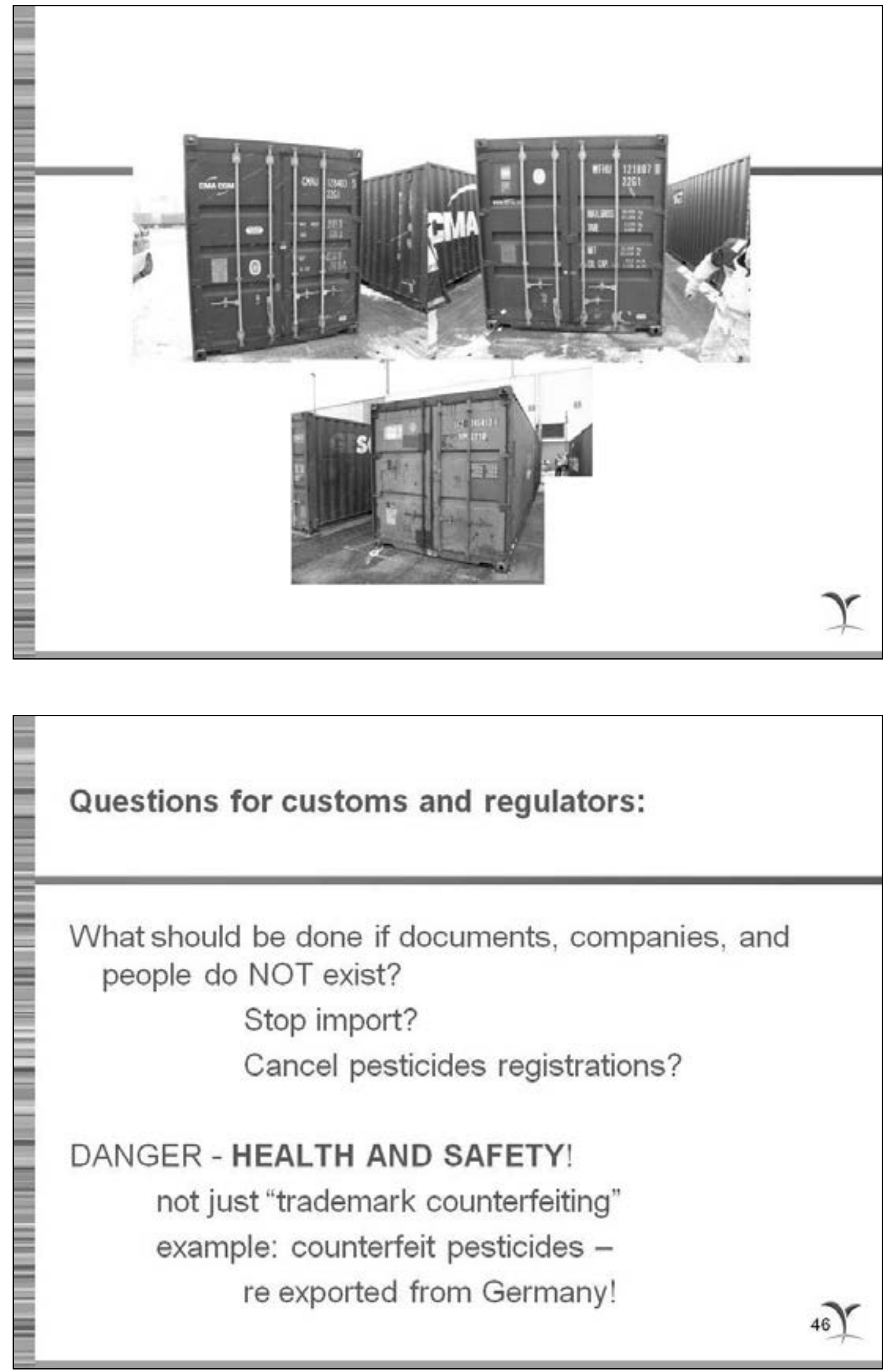


\section{Next steps in prosecution?}

Counterfeiters from China to EU have been identified.

What are the police, authorities, and regulators doing in the follow up of these identified counterfeiters?

\section{New EU risk looks like Paraguay!}

Counterfeiters will now ship only Al

Counterfeit packaging will be shipped separately

Solution: ICAMA database on exporters available to customs and regulators?

Solution: Should documents from export to import follow the $\mathrm{Al}$ and pesticides? 